
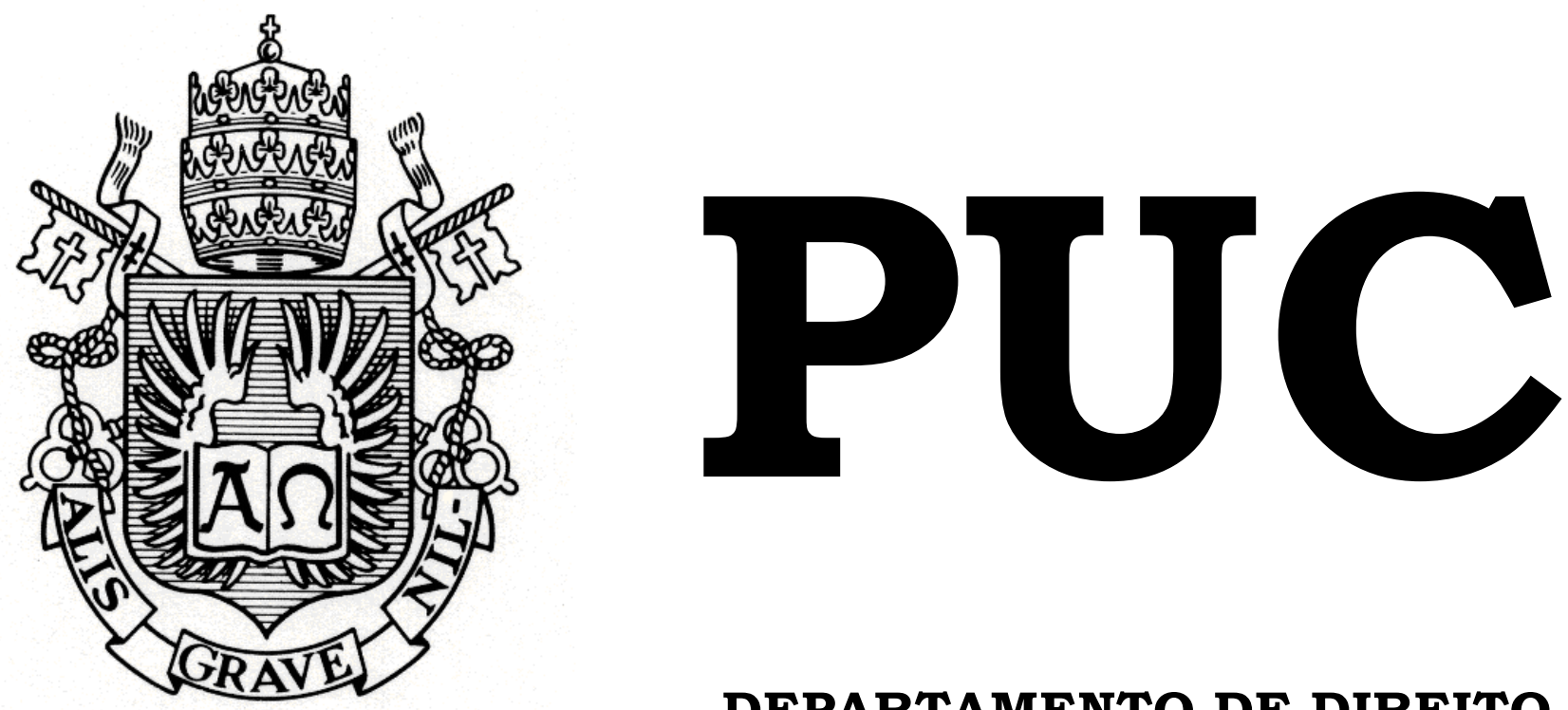

\title{
COMPETÊNCIAS DELIBERATIVAS DE CORTES CONSTITUCIONAIS
}

\author{
por \\ PEDRO PAULO OLIVEIRA DE SOUZA RIBEIRO
}

ORIENTADOR(A): Rachel Barros Nigro

2018.2

PONTIFÍCIA UNIVERSIDADE CATÓLICA DO RIO DE JANEIRO

RUA MARQUÊS DE SÃO VICENTE, 225 - CEP 22453-900

RIO DE JANEIRO - BRASIL 


\section{COMPETÊNCIAS DELIBERATIVAS DE CORTES CONSTITUCIONAIS}

por

PEDRO PAULO OLIVEIRA DE SOUZA RIBEIRO

Trabalho monográfico apresentado ao Departamento de Direito da Pontificia Universidade Católica do Rio de Janeiro (PUC-Rio) para a obtenção do Título de Bacharel em Direito.

Orientador(a): Rachel Barros Nigro

2018.2 


\section{Agradecimentos}

Agradeço, primeiramente, à colaboração infindável desta estimada orientadora, mais que professora, uma guia, Rachel Barros Nigro, a qual viabilizou este ousado e verdadeiro desafio. Nesses termos, agradeço ao professor Fernando Andrea por sua generosidade, receptividade, além do incentivo, sendo impossível deixar de mencionar o suporte e estímulo do professor Dante Braz Limongi ao direito constitucional comparado.

Também gostaria de agradecer aos meus companheiros de curso, tais como Guilherme Mejido, Melanie Pires Toledo e Rodrigo Miguel, pessoas as quais colaboraram a consecução dessa obra. Sem a contribuição destes, teria sucumbido em meio à turbulência de alguns semestres.

Necessário prestigiar o historiador Eric Fagundes Carvalho, o qual me ofertou sua argúcia em momentos fundamentais de minha recente vida acadêmica. Nesta mesma linha, agradeço imensamente aos esforços intelectuais e motivacionais, passados e recentes, de pesquisadores como o economista Rafael Barbieri Camatta e o advogado Rodolfo Mattos.

Ao longo deste percurso, também não poderia deixar de citar a fraternal presença do amigo, professor e estatístico Marcello Provenza e dos fiéis companheiros Bruno Araújo Ferreira e Rodrigo Corrêa Doti. Nesta árdua caminhada seria indispensável reverenciar um amigo do quilate de Plínio Queiroz e jamais poderia esquecer de tantos e tantas que me incentivaram nos percalços e dificuldades das mais variadas origens, tais como Álvaro Rios, Josias Alves de Souza e José Almir Marques.

Reservo um agradecimento especial à Mylena Andrade, mais que uma amiga e aliada em todos os momentos, inclusive de maior ebulição e pressão, nos quais se mostrou disposta a aplacar qualquer desânimo.

Por fim, à estimada e querida professora, arquiteta e urbanista, além de mãe, Isabel Cristina Eiras de Oliveira. Sem ela, absolutamente, não teria chegado a este lugar e nem ao mundo. Já em outro mundo, agradeço a meus saudosos avós, Palmyra Eiras de Oliveira e Wilson de Oliveira por toda a dedicação em vida. Fica um registro sincero a todos e todas que, de certo modo, atravessaram meus caminhos e os percalços deste trabalho. 


\section{Resumo}

Conciliando direito e política, esta monografia desvenda uma forma de analisar o processo decisório de cortes constitucionais explorando a ferramenta teórico-analítica elaborada por Conrado Hübner Mendes (2013). Buscando mensurar a qualidade decisória desta categoria institucional nas diferentes democracias contemporâneas, sua tese sobre o desenvolvimento de competências deliberativas capta nova função às cortes constitucionais. Sob esta função, apuram-se as ideias de uma corte deliberativa como tipo ideal de corte constitucional e de um modelo avaliativo de desempenho deliberativo enquanto equipamento crítico apto a mensurar a distância entre a atuação de uma corte específica e os parâmetros requisitados por este tipo. Tendo por hipótese a viabilidade do modelo e de sua aplicação prática ao Supremo Tribunal Federal (STF), seus elementos foram organizados e transformados no mapa deliberativo do processo decisório constitucional. Ao estruturar um guia prático de análise institucional, segundo as lentes deste autor, o presente trabalho resulta na sistematização de competências deliberativas como um meio para pesquisar a legitimação política em cortes constitucionais. Tal sistematização, entretanto, avança novas possibilidades investigativas ensejando complementações para além do próprio modelo inaugurado por Mendes. Com a criação desta plataforma heurística, almejase contribuir às presentes e futuras pesquisas sobre a corte brasileira.

\section{Palavras-chave}

Deliberação. Metodologia. Modelo avaliativo. Desempenho deliberativo. Competências deliberativas. Democracia. Processo decisório constitucional. Legitimidade política. Poder Judiciário. Reformas institucionais. Separação de poderes. Controle de constitucionalidade. Corte constitucional. Supremo Tribunal Federal. Teoria constitucional. Teoria democrática. Brasil. Direito. Ciência Política. 


\section{Sumário}

1. Introdução

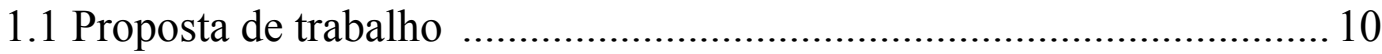

1.1.1 Como analisar uma corte constitucional? ............................... 10

1.1.2 Encontrando um método …………………………………..... 11

1.1.3 Porque utilizar este método ..................................................... 12

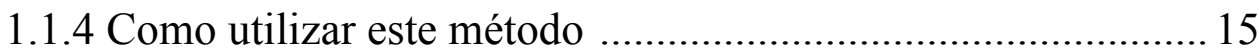

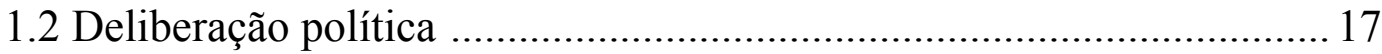

1.2.1 O propósito institucional .................................................... 17

1.2.2 O que é e como deliberar ..................................................... 19

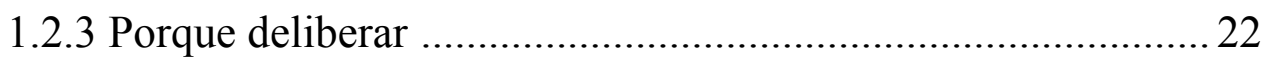

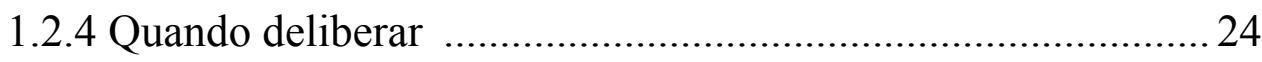

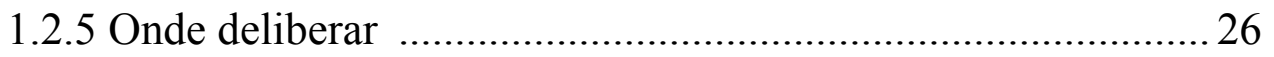

1.3 Deliberação judicial e escrutínio constitucional ...................................... 30

1.3.1 O nível de formalidade ....................................................... 30

1.3.2 $\mathrm{O}$ conceito de legitimidade política ...........................................33

1.3.3 As propriedades institucionais ............................................... 36

1.3.4 Os padrões deliberativos de autoridade judicial ......................39

1.3.5 Aspectos a serem explorados ................................................. 41 


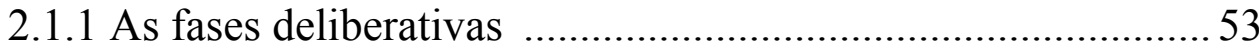

2.1.2 As capacidades deliberativas .................................................5

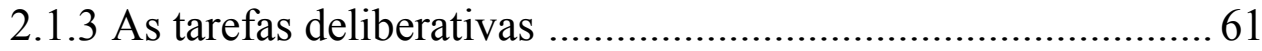

2.2 Os facilitadores do desempenho deliberativo ........................................68

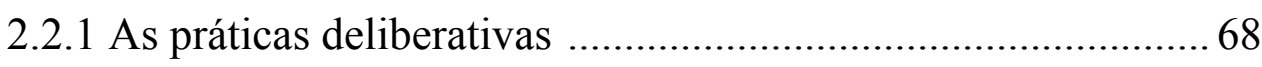

2.2.2 As virtudes deliberativas ...................................................... 70

2.2.3 Os instrumentos deliberativos dispositivos ............................... 88

2.2.4 Os instrumentos deliberativos constitutivos ......................... 107

2.3 Os delimitadores do desempenho deliberativo ................................... 115

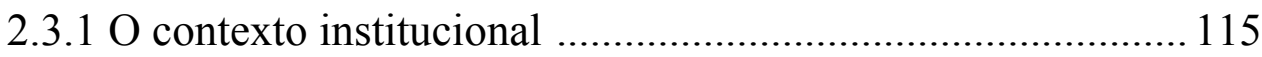

2.3.2 As circunstâncias institucionais ............................................. 141

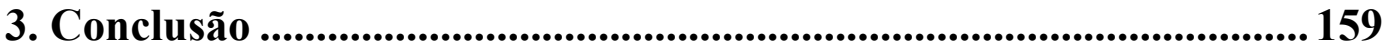

4. Referências Bibliográficas .................................................................. 169 


\section{Abreviações}

Art./ Arts. - Artigo/Artigos

ADPF - Arguição de Descumprimento de Preceito Fundamental

CF - Constituição Federal

CLACSO - Conselho Latino-Americano de Ciências Sociais

CNJ - Conselho Nacional de Justiça

CONPEDI - Conselho Nacional de Pesquisa e Pós-Graduação em Direito

EC - Emenda Constitucional

LC - Lei Complementar

Min - Ministro de Estado

STF - Supremo Tribunal Federal

OAB - Ordem dos Advogados do Brasil

RISTF - Regimento Interno do Supremo Tribunal Federal 


\section{INTRODUÇÃO}

\section{Apresentação}

"As instituições estão funcionando". $\mathrm{Na}$ recente história brasileira esta frase apareceu nas declarações de diferentes agentes políticos e sociais. Marcando a atual crise político-institucional, esteve registrada na cobertura jornalística dos principais meios de comunicação social do país. ${ }^{1}$ Ao longo do triênio 2013-2016, contudo, o volume de publicações envolvendo esta expressão relevaria muito do atual debate sobre a "democracia brasileira".

Entre a eclosão das "Jornadas de Junho" e a realização dos Jogos Olímpicos no Rio de Janeiro, a instalação desta crise acarretou uma série de efeitos práticos os quais perduram até o ano em que a Constituição Federal (CF) completa seus 30 (trinta) anos. ${ }^{2}$ Desse modo, a nova crise republicana aparenta pôr em xeque o princípio de legitimidade do regime democrático brasileiro ao afetar sua capacidade de justificação política. ${ }^{3}$ Dadas estas circunstâncias, a conjuntura atual transforma a afirmação inicial em uma interrogação e a pergunta fundamental, portanto, não passa mais por saber se as instituições estão funcionando, mas sim como estão funcionando.

\footnotetext{
${ }^{1} \mathrm{O}$ fraseado parece surgir na esfera pública atual durante a posse de Luís Roberto Barroso como Ministro do STF. Neste evento, o Min. Marco Aurélio Mello teria utilizado a expressão em tom tranquilizador, coincidindo e contrastando com o ápice das manifestações de rua promovidas nas "Jornadas de Junho". Ver reportagem "Luís Roberto Barroso toma posse como ministro do Supremo", do portal de notícias G1, publicada no dia 26 de junho de 2013, disponível em: http://g1.globo.com/politica/noticia/2013/06/luis-roberto-barroso-toma-posse-como-ministro-dosupremo.html. Este seria o início da última debacle governamental no Brasil (2013-2016).

${ }^{2}$ Promulgada pela Assembleia Nacional Constituinte (ANC) em 5 de outubro de $1988-6^{\text {a }}$ Rep.

${ }^{3}$ Ver FARIA, José Eduardo. A crise constitucional e a restauração da legitimidade. Revista de Ciência Política, v. 28, n. 2, 1985; BONAVIDES, Paulo. Jurisdição constitucional e legitimidade (algumas observações sobre o Brasil). Revista Estudos Avançados, v. 18, n. 55, 2004; DINIZ, Antonio Carlos de Almeida. Teoria da legitimidade do Direito e do Estado: uma abordagem moderna e pós-moderna. São Paulo: Landy Editora, 2006; e BARBOSA, Claudia M. O Processo de legitimação do Poder Judiciário Brasileiro. Anais do XIV Congresso do CONPEDI em 2014.
} 
Dito isto, desde seu nascimento em 1988, após vinte e um anos de regime militar, o regime democrático brasileiro amadureceu entre dois processos de impeachment presidencial e talvez atravesse sua pior crise republicana desde 1960. ${ }^{4}$ Eivadas por um litígio ideológico em relação ao termo "golpe de Estado", as atuais contradições políticas e sociais parecem revigorar algumas contradições e tensões deste passado não muito distante. ${ }^{6}$

Este abalo de 2013 a 2016 trouxe ao debate público a questão sobre se estar ou não em um regime de exceção dada a legitimidade da CF posta à prova a partir do funcionamento de suas instituições políticas. Dessa forma, o Poder Judiciário é alvo da esfera pública a partir da imagem do Supremo Tribunal Federal (STF). No curso da recente democracia brasileira, seu papel e sua atuação institucional poderiam colaborar à maior compreensão de uma "crise dos $30 " .7$ Afinal, pondo em questão o seu propósito, algumas decisões judiciais produzidas por essa corte têm forte repercussão política.

Desde o julgamento da Ação Penal 470 no ano de 2012, passando pelas implicações da polêmica Operação Lava-Jato, deflagrada em março de 2014, até a conclusão de um novo processo de impeachment presidencial em agosto de 2016 e do julgamento do pedido de habeas corpus de um exPresidente da República em abril deste ano, se tornou inevitável perguntar: como o Supremo Tribunal Federal está funcionando?

\footnotetext{
${ }^{4}$ Ver FICO, Carlos. Ditadura militar brasileira: aproximações teóricas e historiográficas. Revista Tempo e Argumento, Florianópolis, v. 9, n. 20, p. 05-74, jan./abr. 2017; e LEMOS, Renato. Contrarrevolução e ditadura no Brasil: elementos para uma periodização do processo político brasileiro pós-1964. Revista Marx e o Marxismo, v. 2, n. 2, p. 111-138, abr. 2014; entre outros.

${ }^{5}$ Fernando Collor de Mello, entre setembro e dezembro de 1992, e Dilma Vana Rousseff, entre dezembro de 2015 e agosto de 2016. Ver discurso de Collor no Senado Federal em 10/05/2016.

${ }^{6}$ Para saber mais sobre a crise social da década de 1960, recomendamos: OLIVEIRA, Franklin de. Revolução e contrarrevolução no Brasil. Rio de Janeiro: Civilização Brasileira, 1962; FURTADO, Celso. A pré-revolução brasileira. Rio de Janeiro: Fundo de Cultura, 1962; e GUILHERME, Wanderley. Introdução ao estudo das contradições sociais no Brasil. Rio de Janeiro: ISEB, 1963.

${ }^{7}$ Cf. MENDES, Conrado Hübner. "A Constituição na crise dos 30”. Artigo em comemoração aos vinte anos da Revista Época, publicado na edição n. ${ }^{0} 1.039$ de 28 de maio de 2018, p. 122.
} 
Como veremos a seguir, a principal obra empregada neste esforço teve sua publicação datada exatamente do catártico ano de 2013 e pode ser assimilada como um produto da pergunta acima. E por que escolher a obra em questão? Em 2002, quando iniciou sua carreira como pesquisador, seu autor passaria a investigar a relação entre a concepção teórica de um regime democrático constitucional e a especificidade desta categoria institucional.

Entre os termos de estudos institucionais, sua obra oferta oportuno panorama sobre a função das cortes constitucionais na democracia atual. Ao mesmo tempo, entre os termos dos debates teóricos sobre legitimidade, assevera uma perspectiva política sobre como observar o funcionamento de instituições jurídicas. ${ }^{8}$ Por isso esmiuçamos sua tese e a transformamos em um guia de aplicação prática voltado à pesquisa sobre o STF.

A presente monografia, portanto, almeja concretizar uma proposta de trabalho abrindo portas não apenas à crítica, mas também à aplicação e complementação do modelo analítico inaugurado por este autor. Tendo o processo decisório constitucional como foco de análise, sua tese informa a deliberação como uma unidade de medida capaz de mensurar a qualidade decisória de cortes constitucionais sob um ponto de vista democrático. ${ }^{9}$ Daí a pergunta mais básica: afinal, como analisar uma corte constitucional?

\footnotetext{
${ }^{8}$ Sobre a queda de apoio à democracia, recomenda-se informe da organização não-governamental Latinobarómetro, criada em 1995 e sediada no Chile: "El declive de la democracia se acentúa en 2017, con bajas sistemáticas del apoyo y la satisfacción de la democracia, así como de la percepción de que se gobierna para unos pocos. El informe da cuenta de múltiples indicadores que también confirman la baja". Ver o item "II.8.2 La confianza en instituciones" e o tópico "Confianza en el Poder Judicial", p. 21 e p. 24, respectivamente. Este estudo recebeu apoio do Banco Interamericano de Desenvolvimento (BID), do Instituto de Integração da América Latina (INTAL) e do Banco de Desenvolvimento da América Latina (CAF). Publicado em 30 de janeiro de 2018 e disponível em: http://www.latinobarometro.org/latNewsShow.jsp. Ver CLACSO.

${ }^{9}$ Ver POST, Robert e SIEGEL, Reva. Constitucionalismo democrático: por una reconciliación entre Constitución y Pueblo. Buenos Aires: SigloVeinteuno, 2013; POST, Robert. Citizens divided - Campaign Finance Reform and the Constitution. Harvard University Press, 2014; e também TEACHOUT, Zephyr. Corruption in America: from Benjamin Franklin's Snuff Box to Citizens United. Harvard University Press, 2014; além da decisão de Bush v. Gore, 532 U.S. 98 (2000).
} 


\subsection{Proposta de trabalho}

\subsubsection{Como analisar uma corte constitucional $?^{10}$}

Partimos de uma pergunta básica e abrangente: como decidem as cortes constitucionais? Incorreu então uma questão antecedente: qual seria a função dessa instituição? Ou melhor, qual o papel a ser exercido por cortes constitucionais nas democracias contemporâneas? Logo, perguntar se o STF é uma corte constitucional implica saber o que deveria ser uma corte e para sabe-lo precisamos avaliar o que uma corte constitucional deveria ser.

Recorremos à obra do cientista político e filósofo do direito Conrado Hübner Mendes pois, segundo ele, cortes podem e devem ser deliberadoras, ou seja, desenvolverem determinadas competências as quais ausentes empobrecem essas democracias constitucionais. ${ }^{11}$ Para Mendes, a apreensão desta função se mostraria mais perspicaz que todas as alternativas teóricas esboçadas até agora. Pretendemos conhecer seu método e explorá-lo. ${ }^{12}$

O principal argumento do autor resulta de um debate envolvendo a legitimidade política do controle de constitucionalidade ao ser exercido exclusivamente por cortes constitucionais. Assim, das literaturas jurídica e política advém o debate sobre como apurar esta legitimidade. Desse modo, apresentaremos as bases elementares para a realização de nosso trabalho monográfico pautados em como este autor responde à essa questão teórica.

\footnotetext{
${ }^{10}$ Guardadas as proporcionais diferenças, essa expressão será utilizada em sentido amplo. Para este trabalho importará apenas a capacidade desta instituição em declarar a inconstitucionalidade de leis. Também ressaltamos o emprego de sinônimos como as expressões "corte" ou "cortes".

${ }^{11}$ Graduado em Direito pela Pontifícia Universidade Católica de São Paulo (PUC-SP) entre 1995 e 1999; Mestre e Doutor em Ciência Política pela Universidade de São Paulo (USP) entre 2001 e 2008; Doutor em Direito pela Universidade de Edimburgo entre 2006 e 2011; e Pós-doutor por diversas instituições de ensino superior estrangeiras, entre 2009 e 2014. Bolsista CAPES/CNPQ.

${ }^{12}$ Frisamos as bases da proposta de Mendes, vinculadas a um critério deliberativo como única plataforma compatível à democracia constitucional atual, sofrerem contestações. Nem todos os autores dessas literaturas endossam a "maior perspicácia" conforme as argumentações do autor.
} 


\subsubsection{Encontrando um método}

Se cortes deliberam, deduz-se que devem fazê-lo da melhor forma possível. Partindo dessa premissa, Mendes prescreve uma corte deliberativa como tipo ideal de corte constitucional e viabiliza um modelo avaliativo de desempenho deliberativo como dispositivo heurístico capaz de aferir quão democrático é o processo decisório em uma corte constitucional. A seguir, resumimos a história dessa construção intelectual em três etapas integradas.

$\mathrm{Na}$ primeira delas, o autor interpretou o debate teórico no tocante a revisão judicial apresentando os principais protótipos de autoridade sobre o significado constitucional. ${ }^{13}$ Para Mendes, ambos se estruturariam na ideia de "última palavra" e na defesa de uma "supremacia" proposta numa escala bipolar entre parlamentos e cortes. Em seguida, aplicou esses argumentos ao regime constitucional brasileiro e problematizou sua notória rigidez. ${ }^{14}$

$\mathrm{Na}$ segunda etapa,${ }^{15}$ para afirmar a maior proficiência das teorias do diálogo institucional em forjarem uma abordagem gradualista, ${ }^{16}$ indicou os erros da polarização anterior e concluiu a possibilidade do debate sobre a autoridade institucional perder de foco o aspecto interativo e de longo prazo da política além da própria variabilidade presente em sua legitimidade. Por fim, na última etapa, Mendes elaborou parâmetros específicos para apurar a legitimidade política no processo decisório constitucional. ${ }^{17}$

Em suma, este referencial define um parâmetro geral a esse tipo de instituição democrática e cria uma ferramenta analítica capaz de explora-lo. Como este aparato de Mendes será capaz de avaliar o desempenho de uma corte constitucional do mundo real, tal qual o STF, é o desafio proposto.

\footnotetext{
${ }^{13}$ MENDES, Conrado Hübner. Controle de constitucionalidade e democracia, 2004.

${ }^{14}$ MENDES, Conrado Hübner. Direitos fundamentais, separação de poderes e deliberação, 2008.

${ }^{15}$ MENDES, Conrado Hübner. Is it all about the last word?, 2009.

${ }^{16}$ MENDES, Conrado Hübner. Not the last word, but dialogue, 2009.

${ }^{17}$ MENDES, Conrado Hübner. Constitutional courts and deliberative democracy, 2013.
} 


\subsubsection{Porque utilizar este método}

Aceitamos o desafio em pesquisar a respeito da função e atuação de cortes constitucionais devido a crescente preocupação teórica sobre o seu comportamento e de seus membros afetarem os sistemas democráticos constitucionais, como no Brasil. Assim, escolhemos este autor por sua tese partir de um quadro geral sobre como o funcionamento desta instituição é visualizado em regimes políticos ocidentais e sublinhar a carência de explicações teóricas mais consistentes acerca do sentido prático de sua atuação, portanto, 'o que', 'como' e 'por que' as cortes decidem?

Para Mendes, direito e política são fenômenos sociais singulares e suas fronteiras se estabelecem de diversas maneiras. Por esse motivo, sua tese introduz argumentos gerais sobre o papel desta categoria institucional e de como este papel pode se tornar mais atraente às democracias. Com base em valores e princípios, prescreve um quadro ideal ou desejável e funda um ponto de vista avaliativo capaz de apontar, comparativamente, os arranjos mais atraentes à uma determinada abordagem democrática, a deliberativa. ${ }^{18}$

Sob as lentes do autor, uma corte constitucional poderá compreender diferentes desenhos institucionais e poderá trabalhar sob as mais distintas culturas jurídicas, tradições argumentativas, textos constitucionais e ambientes políticos. Assim, seus personagens se encontram sob diferentes jurisdições por motivos relacionados não apenas à uma tradição jurídica ou a um projeto institucional, mas também a outros fatores os quais poderiam ser melhor explorados e articulados analiticamente, como o fenômeno das influências institucionais sobre o comportamento judicial. ${ }^{19}$

\footnotetext{
${ }^{18}$ Ver ELSTER, Jon. Deliberative democracy. Cambridge: Cambridge University Press, 1998; e WERLE, Denilson Luís e MELO, Rurion Soares (org.). Democracia deliberativa. São Paulo: Singular, 2007. Para uma crítica, ver artigos do politólogo Luis Felipe Miguel entre 2002 e 2003.

${ }^{19}$ Cf. "A participação da subjetividade no comportamento judicial” em MELLO, Patrícia Perrone Campos. Nos bastidores do Supremo Tribunal Federal. Rio de Janeiro: Forense, 2015, pp. 57-145. Esta autora, por exemplo, trata da participação das instituições no comportamento judicial. Configurando uma abordagem culturalista, pontuaremos este aspecto nas conclusões do trabalho.
} 


\section{Para aprimorar estudos institucionais}

Pautado em 'como', Mendes configurou um equipamento crítico para a avaliar objetos e processos concretos: as cortes constitucionais e seus mecanismos decisórios. Sob um ponto de vista prático, pretendemos avaliar a sensibilidade deste equipamento ao Supremo Tribunal Federal e a partir dos escritos do autor - Desempenho deliberativo de cortes constitucionais e o STF e $O$ projeto de uma corte deliberativa -, extraímos o ponto de chegada o qual desejamos contribuir de alguma forma: ${ }^{2021}$

\footnotetext{
Deste tribunal emanam hoje algumas decisões cruciais da democracia brasileira. Ele não tem sido, entretanto, o espaço do argumento ou da persuasão. Recusa-se, por temperamento, a falar na primeira pessoa do plural. [...] Transformar um tribunal de solistas num tribunal deliberativo requer mais que rearranjos procedimentais. Exige que juízes, pessoalmente, entendam e valorizem o espírito da deliberação. Que se tornem, enfim, deliberadores. (MENDES, 2012, p. 73)
}

A partir deste trecho, assimilamos as possíveis dimensões do método analizado: propósito, mentalidade, arquitetura e limites institucionais; e o foco de sua abordagem: a perspectiva microssocial do indivíduo. Dois aspectos significativos e complementares, pois a chave de compreensão do Tribunal se forja sob a figura de seus membros, tornando sua interação um aspecto fundamental para investigarmos o modus operandi da própria instituição. Sob o ângulo de 'como' esses indivíduos decidem, investigamos o 'que' e 'quais' seriam as competências funcionais requisitadas por uma instituição de tipo ideal segundo a tese deliberativa de Mendes. Com efeito, as competências deliberativas de cortes constitucionais.

\footnotetext{
${ }^{20}$ Cf. VOJVODIC, Adriana; PINTO, Henrique Motta; GORZONI, Paula; e SOUZA, Rodrigo Pagani de. Jurisdição Constitucional no Brasil. São Paulo: Malheiros, 2012. pp. 53-74.

${ }^{21}$ Cf. MACEDO JR., Ronaldo Porto e BARBIERI, Catarina Helena Cortada. Direito e Interpretação: racionalidades e instituições. São Paulo: Saraiva, 2011. pp. 337-361.
} 


\section{Para desenvolver estudos judiciais}

Para compreendermos em maior profundidade essas competências, ${ }^{22}$ reconhecemos a necessidade em constituir uma ampla agenda de pesquisas desta chave explicativa: as interações na corte. Logo, enquanto dispositivo heurístico, o modelo avaliativo de desempenho deliberativo pode contribuir às pesquisas empíricas como uma espécie de "representação cartográfica" do processo decisório constitucional. ${ }^{23}$ Esta é a nossa aposta para o STF.

Nesse sentido, o dispositivo acima atuaria como pedra angular de um projeto analítico mais amplo. Afinal, devido à proposta de sua estruturação, abordagens de diferentes pesquisas se conectariam ao modelo para informar em maiores detalhes a formação de uma corte constitucional. Dessa forma, o método de Mendes funcionaria como um molde a ser preenchido por outros trabalhos suprindo informações qualificadas capazes de refinar os parâmetros pré-estabelecidos pelo autor. Este modelo não seria apenas articulável, mas também permeável a novas informações por reunir, agrupar e integrar diferentes pesquisas sobre uma corte em particular: o STF.

Aproveitando esta maleabilidade, nosso maior objetivo é estruturar o modelo avaliativo de modo a dinamizar sua aplicação prática realizando um "levantamento topográfico" do processo decisório de uma corte. ${ }^{24}$ Com isso esperamos facilitar não só a compreensão, mas também o manuseio deste equipamento crítico e, ao mesmo tempo, reconhecer o terreno para novas pesquisas. Assim, vislumbramos formular um "guia exploratório" capaz de orientar futuras investigações sobre o Supremo Tribunal Federal no Brasil.

\footnotetext{
${ }^{22}$ A obra Constitutional courts and deliberative democracy (2013) é produto de toda a trajetória do autor, mas especialmente de sua tese de doutorado em filosofia do direito, Deliberative performance of constitutional courts, defendida na Universidade de Edimburgo em 2011.

${ }^{23}$ Cartografia. Conjunto de estudos e operações científicas, técnicas e artísticas a orientar os trabalhos de elaboração de cartas geográficas. Uma descrição ou tratado sobre mapas.

${ }^{24}$ Topografia. Descrição ou delineação exata e pormenorizada de um terreno ou região contendo acidentes geográficos naturais ou artificiais. Descrição minuciosa da parte de um organismo.
} 


\subsubsection{Como utilizar este método?}

Como visto, sobre a questão da capacidade desse aparato em avaliar o desempenho do STF, nossa hipótese é ensaiar uma aplicação prática. O tipo ideal adotado será o de uma corte deliberativa e seus indicadores estarão dispostos segundo o modelo avaliativo de desempenho deliberativo. A partir dessa proposta, o ensaio exigirá descrever uma corte deliberativa para traçarmos uma imagem ideal do processo decisório constitucional. ${ }^{25}$

Tendo por base as referidas competências deliberativas, almejamos desmontar o dispositivo de Mendes e remontá-lo a fim de compreendermos sua composição. Isto facilitará a visualização de suas estruturas. Ao final, reuniremos todos os seus componentes para expormos nossas conclusões a respeito da aplicabilidade deste método analítico. Comprovando a hipótese, a construção do ensaio fornecerá elementos práticos a serem aproveitados nas futuras avaliações qualitativas feitas caso a caso de modo a atingir o objetivo de aprimorar os estudos decisórios sobre o STF.

Paralelamente, numa tentativa em contribuir ao desenvolvimento de estudos judiciais, indicaremos algumas possibilidades de exploração e complementação ao próprio modelo analítico. Sob diálogos metodológicos com outros autores e pesquisas, acreditamos na possibilidade de alguns dos trabalhos mais recentes colaborarem a uma avaliação mais aprofundada da instituição STF. ${ }^{26}$ Na perspectiva de um projeto analítico mais amplo, nosso desejo é estimular novos estudos enfocando o comportamento institucional de magistrados e apontar caminhos para que seu trabalho judicial possa se tornar mais legítimo segundo mecanismos de controle social mais efetivos.

\footnotetext{
${ }^{25}$ Deliberação. Debate com o objetivo de resolver algum impasse ou tomar uma decisão. Questionamento ou reflexão tendo em vista a resolução de um problema ou o planejamento de uma atitude. Ação empreendida após consulta e/ou reflexão. Deliberatio ou deliberatum.

${ }^{26}$ Por exemplo, os trabalhos de MELLO, Patrícia Perrone Campos. Op. cit.; ou de FONTE, Felipe de Melo. Jurisdição constitucional e participação popular: o Supremo Tribunal Federal na era da TV Justiça. Rio de Janeiro: Lúmen Juris, 2016.
} 


\section{Construindo um mapa deliberativo}

Destarte, o método proposto nesta monografia científica se debruça exclusivamente sobre a descrição de uma tese político-jurídica concentrada em uma única obra. ${ }^{27}$ Nos propusemos a apresentar, estruturar e preencher um modelo de análise dividindo nossa pesquisa em três etapas. De início, após esta proposta (1.1), traçamos um panorama do objeto investigado: fornecemos quadros conceituais sobre a deliberação política (1.2) e também sobre a deliberação judicial aplicada ao escrutínio constitucional (1.3).

$\mathrm{Na}$ etapa subsequente, tratamos de descrever o objeto propriamente dito: formatamos um pequeno roteiro ponto a ponto e ao final apresentamos organicamente os pontos reunidos formando um guia exploratório voltado à análise de competências deliberativas. Com isso, este capítulo desenvolverá os três níveis de desempenho propostos pelo modelo de Mendes: principal significado (2.1); facilitadores (2.2) e delimitadores (2.3); e em cada um desses niveis organizamos seus diferentes indicadores e parâmetros teóricos considerando o uso prático direcionado à pesquisa sobre o STF.

Por fim, conclusivamente, indicamos nossos resultados em relação à aplicação do modelo: o "mapa deliberativo". Assim, após traçarmos este roteiro, precisamos examinar o papel institucional do que pretendemos apresentar como as competências deliberativas de cortes constitucionais. Ou seja, o propósito institucional de uma corte constitucional, sua função. ${ }^{28}$

\footnotetext{
${ }^{27}$ MENDES, Conrado Hübner. Constitutional courts and deliberative democracy. UK: Oxford University Press, 2013. Trabalharemos especialmente os capítulos quatro, cinco, seis, sete e oito, respectivamente "Deliberative performance of constitutional courts"; "The ethics of political deliberation"; "Institutional design: augmenting deliberative potential"; "The legal backdrop of constitutional scrutiny" e "The political circumstances of constitutional scrutiny". Ressaltamos a versão consultada para este trabalho ser uma obra em formato digital o qual não oferta paginação. Dessa forma, nos valeremos de citações indiretas na abordagem e tratamento de seu conteúdo.

${ }^{28}$ Mendes trabalha especialmente com as concepções de John Ferejohn e Pasquale Pasquino. Entre seus trabalhos, indicamos "Rule of Democracy and Rule of Law". In: José Maria Maravall e Adam Przeworski. Democracy and the rule of law. UK: Cambridge University Press, 2003, pp. 242-260.
} 


\subsection{Deliberação política}

\subsubsection{O propósito institucional}

Para Mendes, ao tentarmos justificar a existência de cortes constitucionais, imagens não apenas confundem o público sobre os aspectos intangíveis da adjudicação, também escondem conceitos e argumentos. Estes conceitos prescrevem funções, aumentam expectativas e desenham as fronteiras do trabalho judicial. Dessa forma, segundo o autor, a adjudicação constitucional se concentrou em cinco imagens amplamente utilizadas no debate sobre a caracterização de cortes constitucionais. As imagens abaixo não seriam exclusivas, mas cada uma enfatizaria um aspecto específico sobre o propósito institucional de cortes constitucionais: (MENDES, 2013)

- a corte constitucional como uma força de veto;

- a corte constitucional como uma guardiã da constituição;

- a corte constitucional como um fórum de princípios;

- a corte constitucional como uma interlocutora institucional;

- a corte constitucional como uma deliberadora.

Diante deste conjunto, Mendes sublinhará o fato da última imagem captar um aspecto interno ignorado pelas demais: "as cortes constitucionais serem compostas por um pequeno grupo de decisores comprometidos mútua e argumentativamente a produzirem uma decisão final". Para o autor, este procedimento constituirá uma vantagem em relação as demais funções. Assim, sua hipótese se dará sobre as cortes se beneficiarem de virtudes da deliberação colegiada e, graças às suas condições decisórias, estarem mais propensas em obter melhores respostas sobre a interpretação constitucional. (MENDES, 2013) 


\section{Imagem política e matriz de análise}

A partir dessa ideia, o autor desenvolve o fundamento teórico da imagem a ser explorada neste trabalho. Para Mendes, uma corte se torna deliberadora ao desenvolver suas qualidades deliberativas e, para isso, o tratamento sistemático de seus critérios deverá ser delineado pela teoria normativa se preocupando com a forma como as cortes devem se comportar em uma democracia constitucional. Neste limiar, cada corte só poderá ser entendida e explicada dentro de um contexto muito específico e a tarefa fundamental será prescrever, com base em valores e princípios, os tipos ideais ou desejáveis de como essas cortes devem ser. (MENDES, 2013)

Segundo o autor, embora exista a definição de um "compromisso argumentativo interpessoal", a literatura teórica não consolidou um quadro compreensivo para a deliberação política. $\mathrm{Na}$ falta de maiores distinções, Mendes realizou um trabalho conceitual para tratar significativamente os diversos ângulos desse tipo de deliberação. Buscando uma matriz de análise com a qual pudesse navegar, o autor selecionou a família das teorias da democracia deliberativa. Assim, ao desacoplar a democracia da deliberação, se concentrando nesta última, Mendes juntou algumas de suas partes para formar uma imagem deliberativa de corte constitucional. (MENDES, 2013)

Para apresentar essas partes, montamos um breve esquema forjado em quatro passos consecutivos: "o que é e como", "por que", "quando" e "onde" deliberar. São as quatro perguntas elementares a serem respondidas no início de nossa jornada. Este inquérito corresponderá à identificação das partes capazes de formar uma imagem a qual norteie as práticas, princípios, circunstâncias e instrumentos relativos ao seu modelo avaliativo. A partir desses componentes, respectivamente, formamos o conceito de deliberação política organizado pela tese deliberativa de Mendes (1.2). Em seguida, de forma complementar, o interligamos ao conceito de deliberação judicial e constitucional completando a primeira etapa de nosso trabalho (1.3). Então, o que seria uma deliberação e como se deliberaria na visão deste autor? 


\subsubsection{O que é e como deliberar}

Segundo Mendes, ao tentar estabelecer um fundamento teórico, a teoria democrática recolocou a deliberação como um componente valioso na tomada de decisão coletiva e a apresentou como: "uma prática respeitosa e inclusiva de justificação mútua a buscar continuamente soluções para as demandas decisórias formando uma posição por meio da concessão e apreciação de razões, as quais perseguem, mas não necessariamente alcançam, um consenso sobre o bem comum". (MENDES, 2013)

$\mathrm{Na}$ visão do autor, antes de contarem votos, deliberadores poderiam ser capazes de transformar suas preferências a luz de argumentos bem articulados e persuasivos. Para Mendes, esta definição corresponderia a um mínimo denominador comum. ${ }^{29}$ Dessa forma, por envolver um intricado conjunto de elementos, qualquer processo político decisório o qual falhe em preencher determinados requisitos não mereceria se chamar deliberação. Logo, os componentes desta definição estarão dispostos em sete requisitos formando o que seria a "conquista deliberativa". (MENDES, 2013)

Estes componentes seriam: (1.) pressupor a necessidade em tomar uma decisão coletiva a qual afetará direta e indiretamente a outrem; (2.) não considerar uma decisão como fim de linha, mas um ponto provisório a ser sucedido por novas rodadas deliberativas; (3.) se tratar de uma prática de justificação mútua de sua posição perante seus parceiros; (4.) apresentar razões públicas sob um tipo imparcial de razão traduzível em bem comum; (5.) assumir os deliberadores estarem abertos a revisarem e transformarem suas opiniões a luz do argumento; (6.) envolver o elemento ético do respeito; e (7.) compreender um compromisso político de inclusão, empatia e responsabilidade para com todos os pontos de vista. (MENDES, 2013)

\footnotetext{
${ }^{29}$ Segundo Mendes, vários autores concordariam com a existência de um "mínimo deliberativo" consolidado na literatura teórica. Cita-se como exemplo: John Dryzek; Amy Gutmann, Dennis Thompson; Simone Chambers; Bernard Manin; Robert Goodin; e James Bohman. Para a crítica, ver os trabalhos de MIGUEL, Luis Felipe. Consenso e conflito na democracia contemporânea e Democracia e representação: territórios em disputa. São Paulo: Editora Unesp, 2017 e 2014.
} 


\section{Requisitos da deliberação política}

Estes 7 (sete) requisitos da deliberação política, delineados acima, poderiam ser relacionados e representados da seguinte forma:

$\begin{array}{lll} & \text { Requisitos } & \text { Aspectos } \\ 1 . & \text { de decisão } & \text { "coletivo" e "político" } \\ 2 . & \text { de continuidade } & \text { "provisório" } \\ 3 . & \text { de justificação mútua } & \text { "dialógico" } \\ 4 . & \text { de razões públicas } & \text { "comunitário" } \\ 5 . & \text { de persuasão } & \text { "consensual" } \\ 6 . & \text { de respeito mútuo } & \text { "ético" } \\ 7 . & \text { de cooperação } & \text { "compromissório" }\end{array}$

$\mathrm{Na}$ visão do autor, a deliberação política, em síntese, seria composta por uma variável do raciocínio prático aplicado aos processos de tomada de decisão coletiva. Para Mendes, portanto, qualquer concepcão sobre o bem comum, dentro do ideal deliberativo, precisaria suportar um teste argumentativo consentido não apenas numericamente. (MENDES, 2013)

Segundo o autor, ao descontrair ou restringir esses requisitos, ainda poderia se conceber uma razão pública de modo mais ou menos expansivo tornando suas atitudes éticas e políticas mais ou menos extenuantes e assim por diante. Para Mendes, o que entrará ou sairá aos limites dependerá dos propósitos de cada teoria ao levarem em conta sua aplicabilidade e capacidade justificatória. Ou seja, diferentes misturas desses ingredientes poderão nortear processos decisórios os quais continuem tangenciando um padrão ideal de deliberação, como seria o caso do STF. (MENDES, 2013) 


\section{O que não é e como não deliberar}

$\mathrm{Na}$ outra ponta deste espectro, Mendes sustenta que dois métodos sintetizam, em contraste, o que não seria deliberação: votar e barganhar. A atitude de barganhar consistiria em um tipo de transação de balcão onde as partes estariam dispostas a colocar seus interesses privados sobre a mesa e negociar compensações mútuas de modo a alcançarem um acordo o qual otimize seus respectivos desejos pessoais. ${ }^{30} \mathrm{~A}$ atitude de votar, por sua vez, seria camaleônica e não necessariamente compatível com a deliberação. Para o autor, formalmente, votar seria um método justo para agregar posições individuais e thes fornecer o mesmo peso, mas dependendo de como a posição individual seja formada, votar pode delinear três diferentes arquétipos: (MENDES, 2013)

I - Se votar for apenas o ponto final para alcançar uma decisão a luz de um desacordo residual, não se tornará incongruente, ao invés disso será requerida pelo próprio ideal deliberativo;

II - Se votar for uma agregação de preferências individuais brutas sob um enquadre privado, este ideal exclui o ato de votar;

III - Em um lugar intermediário, votar pode servir para fundir juízos reflexivos sobre o bem comum os quais não passam pelo escrutínio interpessoal. Independente do valor que isto possa ter, esta variável falharia em encontrar as funcionalidades mais básicas da deliberação política. Afinal, nem sempre a votação alcança o ideal deliberativo.

\footnotetext{
${ }^{30}$ Conceitualmente, notamos a incidência do "paradigma do interesse". Ver FORCE, Pierre. Selfinterest before Adam Smith: a genealogy of economic science. US: Cambridge University Press, 2003; e também HUNDERT, E. J. The enlightenment's 'fable': Bernard Mandeville and the Discovery of society. UK: Cambridge University Press, 2005. Recomenda-se a crítica marxista.
} 


\subsubsection{Porque deliberar}

Como vimos, Mendes aponta a existência de diferentes percursos normativos para descrever uma deliberação. Para o autor, mesmo com ênfases distintas, esta deliberação seria engenhosa o bastante para instanciar um protótipo de legitimidade política capaz de satisfazer a extensão de todo o panorama teórico. Sob esta visão, a deliberação conduziria à uma base para a legitimação independentemente de resultados. (MENDES, 2013)

Feita esta menção, Mendes sustenta que o respectivo conjunto de valores incorporados por essa prática dependerá do olhar do espectador. Assim, a deliberação política possuiria um impulso capaz de pôr em relevo diferentes conjuntos de valores. Para o otimismo do autor, os modernos valores políticos (liberdade, igualdade, e comunidade) estariam implicados neste tipo de deliberação. Neste sentido, o processo deliberativo seria capaz de reconciliar essas diferentes perspectivas políticas. (MENDES, 2013)

Paralelo a esse plano valorativo, o autor ressalta a existência de uma diferença entre seu elemento constitutivo e o que se espera que se produza, seu elemento derivado. Ressaltando, portanto, a existência de uma diferença entre os valores da deliberação e suas supostas consequências. De modo a evitar uma circularidade, alerta-se a distinção sobre o que é constitutivo da deliberação e o que seria derivado a partir dela. Para Mendes, seus valores e consequências não devem ser confundidos. (MENDES, 2013)

Diante deste esclarecimento, o autor nos informa que caso alguém queira participar da deliberação, seu quadro conceitual - o que é e como deliberar - indica quais atitudes seu participante precisa cultivar. Já os seus valores - porque deliberar -, ao contrário, dispõem os respectivos terrenos intrínsecos, o lado não-consequencialista dos motivos em valer a pena o seu participante deliberar. Para Mendes, esses dois movimentos conceituais atitudes e valores, precisam ser concebidos de antemão a nível teórico e normativo. (MENDES, 2013) 


\section{Conquistas deliberativas}

Como atestado, a teoria política também foi elaborada a partir dos resultados que este processo se dispõe a apresentar. Segundo Mendes, essas razões instrumentais seriam parte oriunda da onda teórica de resultados e retratariam a deliberação como ferramenta a atingir finalidades externas. Para o autor, este tipo de razão mostra o que um participante deve esperar ao concluir coletivamente. No entanto, também se deve atentar ao fato da deliberação política não se dar sem riscos e nem mesmo ser algo infalível. Como veremos, suas falhas potenciais, em certos contextos, poderão sopesar ocasionais benefícios diante das circunstâncias. (MENDES, 2013)

Assim, o autor aponta quatro tipos de consequências ou "conquistas deliberativas": a epistêmica; a comunitária; a psicológica; e a educativa. A conquista epistêmica, poderia promover clareza sobre questões que estão postas e alcançar uma melhor resposta; a conquista comunitária poderia encorajar o consenso, ou ao menos minimizar o dissenso, nutrindo a legitimação social e aprofundando o senso de comunidade; a conquista psicológica poderia incutir o sentimento de ser respeitado; e, por fim, a conquista educativa poderia educar os participantes sobre o conteúdo da questão e sobre suas próprias habilidades deliberativas. Essas conquistas coexistiriam e se fortaleceriam, creditando um possível meio a encorajá-las. (MENDES, 2013)

Mas por que alguém deveria aceitar que a deliberação preencheria essas promessas? Sob quais bases a teoria normativa poderia prever os resultados de um determinado processo de tomada de decisão? Para Mendes, essas conjecturas seriam feitas por intermédio de estimativas as quais podem ser confirmadas ou falseadas pelo questionamento empírico. Nesta consideração, o autor declara incidir um profundo debate sobre essas promessas estarem definidas em termos de plausibilidade e probabilidade. Já seus riscos, por outro lado, seriam salientados pelas refutações empíricas e daí a necessidade em aplicar um modelo avaliativo. (MENDES, 2013). 


\subsubsection{Quando deliberar}

Até aqui a deliberação política seria conceituada fora de qualquer contexto específico. Para Mendes, esses contextos envolvem viabilidade e conveniência. Perguntamos em termos abstratos o que seria deliberação, como praticá-la, por que seria valiosa e o que se esperaria dela. Segundo o autor, essas questões não poderiam ser respondidas satisfatoriamente sem maior inquérito. Assim, o retrato acima poderia sugerir a legítima política consistir em submeter as pessoas a um processo de conceder e reter razões deixando a força do melhor argumento dominar. Para o autor, raramente este seria o caso. Às vezes a deliberação política se mostra inapropriada e, além disso, a política também envolve práticas não deliberativas, porém legítimas. Dessa maneira, conforme veremos, Mendes afirma elementos contextuais ajudarem a detectar sua viabilidade prática. (MENDES, 2013)

Então quando uma comunidade deveria investir seus escassos recursos políticos em deliberações? Nem sempre, dirá Mendes. Mas se é assim, quando não deliberar? Quais fatores poderiam anular uma posição em favor da deliberação como modelo de legitimidade? Segundo o autor, o valor e as promessas de deliberação ajudariam a enxergar por que sua conveniência presuntiva seria sensível, mas não elaborariam a respeito das exceções que anulam essa presunção. Para Mendes, haveriam três testes os quais amenizariam os reclames acima. Cada teste seria o corolário de uma das três variáveis as quais moldam as circunstâncias deliberativas. Juntos, detectam o contexto hostil ou favorável à deliberação. (MENDES, 2013)

$\mathrm{Na}$ visão do autor, esses testes envolveriam sopesar os ganhos e perdas de um processo deliberativo. Afinal, condições nunca são perfeitas e os resultados não são totalmente previsíveis. Passar nos testes implica que após um equilíbrio se deva concluir a possibilidade da deliberação ocorrer. Mendes então esclarece que essa questão não será mais do que o quanto deliberar e quando parar com vista a tomar uma decisão, mesmo que parar signifique, inevitavelmente, uma decisão provisória. (MENDES, 2013) 


\section{Exame antecipado das circunstâncias}

Dito isto, veremos esses três testes mais a frente, quando tratarmos deles na última seção de nosso segundo capítulo - As circunstâncias institucionais (2.3). De toda forma, Mendes enfatiza os testes se resumirem a identificar o ponto de inflexão no qual a insistência na argumentação deixa de ser útil ao seu propósito. Para o autor, em configurações formais, parte desses testes poderá ser estabelecida antecipadamente por meio do desenho institucional, mas certa dose de discricionariedade permanecerá sempre nas mãos dos deliberadores. ${ }^{31}$ (MENDES, 2013)

Segundo o autor, dentro dessa discricionariedade, a atividade se tornará mais intrincada que a inicialmente imaginada. Afinal, antes da deliberação de primeira ordem, um exame de circunstâncias exigiria uma deliberação de segunda ordem. Ou seja, deliberadores devem decidir, em um meta-nível, se e quanto deliberar. Para fazer isso, primeiro precisam ter consciência das circunstâncias institucionais serem importantes, além de estarem equipados para identificá-las e lidar com elas. (MENDES, 2013)

Mendes, portanto, salienta haver um caso padrão para deliberação e o ônus de sua prova dever ser realizado por uma deliberação de segunda ordem a qual será responsável pela aplicação de um exame prévio. Segundo o autor, seria válido sublinhar este conceito de circunstância possuir um ferrão normativo apto a justificar quando deliberadores são perdoados por não deliberar e por isso defender uma deliberação de segunda ordem a qual esclareça tensões a serem tratadas em cada caso concreto. Essa deliberação de segunda ordem, entretanto, não desafiaria o valor da deliberação, mas simplesmente aceitaria exceções sob a clareza da deliberação de primeira ordem não ser recomendável, seja por seus custos se mostrarem elevados, ou por sua mera tentativa entrar em colapso. (MENDES, 2013)

\footnotetext{
${ }^{31} \mathrm{Na}$ visão do autor, prazos para se tomar uma decisão, estabelecendo seu nível de urgência e a obrigatoriedade de uma agenda de casos a serem decididos, seriam alguns desses exemplos. Abordaremos esta questão na variável dos “facilitadores" do desempenho deliberativo (2.2).
} 


\subsubsection{Onde deliberar}

Mas onde deliberar? Segundo o autor, um local apropriado seria composto de certas variáveis e o nível de formalidade seria um componente elementar. Dessa maneira, existiriam redutos informais e formais onde a deliberação aconteceria. Segundo Mendes, o que basicamente distinguiria ambos é o poder em tomar decisões autorizadas em nome de, e aplicáveis a, uma comunidade política. Logo, um reduto formal, ao contrário de um reduto informal, é institucionalizado e a respectiva legislação constitucional lhe atribuiria competência e jurisdição próprias. ${ }^{32}$ (MENDES, 2013)

Nesses termos, assevera o autor, a conexão entre a deliberação e a democracia não será direta. Esta ligação conceitual não se reduz à dimensão de 'quem' delibera. Sob tal prisma restrito, a deliberação seria democrática na medida em que os cidadãos tivessem voz nela. Assim, segundo Mendes, fóruns populares preencheriam tal acordo, enquanto elitistas não o fariam, mas caso o foco se posicionasse exclusivamente sobre a fatia democrática dessa equação, assumindo essa porção estreitamente concebida como 'quem decide', os benefícios putativos da deliberação se perderiam. Para o autor, portanto, outras variáveis estão acima de 'quem'. (MENDES, 2013)

Consequentemente, em sua percepção, estipular 'quem', 'quantos' e 'como' decidir seria uma derivação dessa atração gravitacional mista, o equilíbrio sensível entre as razões instrumentais - sua competência - e as razões intrínsecas - sua respeitabilidade moral. Para Conrado, neste limite, o desenho institucional se preocupa tanto com a competência institucional, criando uma capacidade em fazer ou maximizar suas chances, quanto com a respeitabilidade moral de sua autoridade. (MENDES, 2013)

\footnotetext{
${ }^{32}$ Para Mendes, ecoaria a concepção habermasiana de um "processo político sob duas vias", isto é, uma estrutura centro/periferia; articulações entre formal e informal; e entre instituições de governo representativo e esfera pública. Assim, esta última contribuiria à formação de opinião enquanto a primeira levaria à formação de vontade coletiva. Ver HABERMAS, Jürgen. Between facts and norms: contributions to a discourse theory of law and democracy. Cambridge: MIT Press, 1996.
} 


\section{Arquitetura de legitimação}

Segundo o autor, por meio do arranjo delineado logo acima, se desenham inúmeras combinações institucionais. Para Mendes, na maioria das democracias contemporâneas, alguma versão do princípio da separação de poderes, mediante suas cadeias de hierarquia e delegação interligadas, organizaria esse esquema geral de autoridade e também o papel relativo a cada fórum específico (ex.: cortes e parlamentos). (MENDES, 2013)

Por meio deste raciocínio, cada instituição teria um propósito epistêmico. Esse propósito provavelmente exigiria realizações diferentes da deliberação, como os diversos tipos e números de deliberadores e uma arquitetura de legitimação adaptada a estes. Diante de um determinado conflito, não se pode crer que um grupo de pessoas, quais forem e por mais numeroso que este seja, ao deliberar sobre qualquer assunto e em qualquer circunstância, se torne mais informado e criativo, descubra premissas profundas e alcance uma melhor resposta institucional. (MENDES, 2013)

Consequentemente, Mendes afirma uma instituição deliberativa contrair mais que esta deliberação intramuros entre seus membros. Assim, uma deliberação extramuros, entre a instituição e interlocutores, poderia ser uma prática esclarecedora. Ao mesmo tempo, uma consideração a qual despreze tal atividade restará inacabada. Logo, considerando a deliberação envolver uma interação entre atores formais e informais, tendo em mente sua continuidade permanente, menciona-se este refinamento ser necessário de modo a isolar as fases em que ocorre a deliberação. (MENDES, 2013)

Para o autor, a deliberação surge como uma sequência interativa de comunicação política incessante a longo prazo e a decisão, portanto, se torna um evento ao longo do caminho no qual decisores deliberam sozinhos apenas em uma dessas fases, seu momento intramuros. Mas por intramuros não quer dizer deliberar em segredo e livre do escrutínio da esfera pública mais ampla. Sigilosa ou pública, a deliberação será intramuros na medida em que os decisores se comprometem apenas entre si. (MENDES, 2013) 


\section{Os elementos deliberativos}

Conforme apuramos, as distinções entre os tipos de deliberadores; as deliberações intra e extramuros; e as fases deliberativas, serão elementos úteis para desenhar a deliberação ou para dar conta de instituições políticas mediante a leitura proposta por Mendes. Da mesma forma, a simbiose entre as esferas formal e informal será um elemento fundamental para maximizar a plausibilidade de todas as promessas de uma deliberação: a) epistêmica; b) comunitária; c) psicológica; e d) educativa. (MENDES, 2013)

Assim, as instituições se mostrarão mais ou menos permeáveis a desencadear e canalizar deliberações fora delas. Para Mendes, instituições podem se tornar ótimos catalisadores deliberativos - interinstitucionais e intrainstitucionais - e um desenho institucional qualificado precisará levar tudo isso em consideração. (MENDES, 2013)

Conclusivamente, nosso autor salienta não ser possível conceber de forma significativa a deliberação sem reconhecer suas circunstâncias quando - e seu respectivo fórum - onde. Este espaço fornecerá uma imagem mais clara da viabilidade de seu quadro conceitual, da adequação dessas promessas deliberativas e das respostas a maioria dos seus riscos, ${ }^{33}$ mas para analisar uma corte constitucional é preciso ter em conta, primeiro, a questão envolvendo sua legitimidade política. (MENDES, 2013)

Com efeito, portanto, é preciso ter em mente cortes constitucionais como fóruns deliberativos distintos e os tipos de requisitos que devem ser cumpridos se as cortes quiserem realizar a "conquista deliberativa". Afinal, o presente debate constitucional está desprovido de um conjunto de padrões qualitativos os quais orientem a avaliação de como diferentes cortes podem operar em relação aos termos de sua virtude decisória. (MENDES, 2013)

\footnotetext{
${ }^{33}$ Segundo Mendes, mencionando David Estlund, a combinação certa de circunstâncias, arranjos institucionais e caráter pessoal poderia minimizar os possíveis efeitos negativos da deliberação. In: COPP, David et al. The idea of democracy. Cambridge University Press, 1993, p. 72. Logo, desta concepção parece advir as propostas de reformas institucionais e normas deliberativas para cortes.
} 


\section{Imaginando cortes deliberativas}

Então, como uma corte constitucional pode ser imaginada como deliberativa? É o que veremos, mas antes fornecemos um quadro geral dos passos conceituais dados ao longo desta seção e a partir deles identificamos as questões e elementos presentes em uma deliberação política.

\begin{tabular}{|c|c|c|}
\hline Passo & Questões & Elemento \\
\hline $1^{\circ}$. Definição .. & O que é e co & Atitudes \\
\hline \multicolumn{3}{|c|}{ 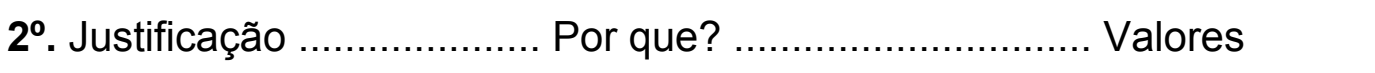 } \\
\hline \multicolumn{3}{|c|}{$3^{\circ}$. Contextualização ............ Quando? ............................. Circunstâncias } \\
\hline $4^{\circ}$. Localizaçãc & Onde? ......... & Razões \\
\hline
\end{tabular}

Em seguida, temos uma continuação do quadro anterior relacionando cada um dos elementos acima aos seus componentes internos e respectivos preceitos normativos. Estes preceitos serão trabalhados pelo autor em seu modelo de modo a juntar as partes abaixo e formar a imagem deliberadora como tipo ideal de corte constitucional, ou seja, uma corte deliberativa.

\begin{tabular}{|c|c|c|}
\hline Elemento & Componentes & Preceitos \\
\hline $1^{\circ}$. Atitudes ............... & .... Requisitos ..... & Argumentativos \\
\hline $2^{\circ}$. Valores ............... & .... Promessas ..... & Legitimatórios \\
\hline $3^{\circ}$. Circunstâncias . & .... Testes ....... & Condicionantes \\
\hline $4^{\circ}$. Razões ............... & ... Formatos ......... & Institucionais \\
\hline
\end{tabular}




\subsection{Deliberação judicial e escrutínio constitucional}

\subsubsection{O nível de formalidade}

Vimos um quadro conceitual - o que é e como deliberar - e as atitudes a serem cultivadas, o lado consequencialista dos motivos em deliberar. Também vimos os terrenos intrínsecos - porque deliberar - e os valores a serem preservados ao deliberar, seu lado não-consequencialista. Como ferramenta a atingir resultados, além desses movimentos conceituais, vimos seu conceito de circunstância - quando deliberar -, implicar uma deliberação prévia a examinar as condições para deliberar. Finalmente, vimos um fórum - onde deliberar -, configurando uma arquitetura de legitimação ao equilibrar razões instrumentais (competência institucional), e razões intrínsecas (respeitabilidade moral) sob certo nível de formalidade.

Para o autor, dentro de toda essa arquitetura, portanto, interligar a adjudicação à deliberação se tornará uma tarefa delicada. Existiriam dois ângulos por meio dos quais esta questão é conceituada. Segundo Mendes, haveria um vínculo dentro do próprio raciocínio jurídico no qual o direito é deliberativo ao permitir o equilíbrio das razões de agir baseadas em regras. Desse modo, não seria possível viver de acordo com o direito sem se comprometer discursivamente com ele. (MENDES, 2013)

Em segundo lugar, o autor afirma haver um vínculo institucional, pois magistrados deliberam entre si dentro de uma adjudicação colegiada. A deliberação, em um primeiro sentido, corresponderia ao mero papel da reflexividade e, neste último, corresponderia a um compromisso interativo de argumentação. Assim, "colegiado" seria uma definição formal e técnica, um órgão decisório formado por múltiplos membros compartilhando a responsabilidade pela decisão. Por sua vez, "colegial" seria uma definição ética e cultural, uma atitude em relação aos deliberadores buscando uma decisão supra-individual e des-personificada. Por fim, "colegialidade" seria um termo o qual poderia referir-se às duas categorias. (MENDES, 2013) 


\section{Entre casos fáceis e casos difíceis}

Sob o prisma desta última - "colegialidade" -, e diante da conexão entre adjudicação e deliberação, invariavelmente permaneceria uma troca mais ou menos vigorosa de diferentes argumentos a qual tenta encontrar a melhor solução aos casos fáceis e também aos casos dificeis. Para Mendes, isto seria suficiente para reconciliar o direito à deliberação em ambas as perspectivas. Em casos difíceis, chamando-a ou não de extrajurídica, haveria deliberação ao se construir uma solução de forma argumentativa; e em casos fáceis, onde essa oposição polêmica perde muito de sua densidade prática, também poderia haver uma deliberação por mais permeada que esta seja às razões baseadas em regras. (MENDES, 2013)

Segundo o autor, instituições constituem um teatro deliberativo e, ao fazê-lo, limitam a deliberação não apenas do ponto de vista processual, mas também em termos de razões as quais sejam válidas nesse cenário. $\mathrm{O}$ funcionamento de qualquer sistema jurídico denota um grau apropriado de formalidade, uma capacidade em selecionar razões aceitáveis no discurso jurídico independente de seu calibre substantivo. (MENDES, 2013)

Para Mendes, ao argumentar no domínio do direito, alguns filtros reduzem o número e a qualidade de razões disponíveis. Logo, a fim de saber quais argumentos serão classificados como argumentos jurídicos ou não, é necessário observar não as próprias regras, mas sim a "imagem do direito", uma construção social incorporada à uma cultura a qual estabelece o próprio aparato jurídico em movimento. (MENDES, 2013)

$\mathrm{Na}$ visão do autor escolhido, tal fechamento da linguagem jurídica, pressuposto pelo Estado de direito, corresponderia a um "cânone" e como eo cânone de argumentos jurídicos varia, também o fazem os limites da deliberação dentro do direito e por isso este caráter formal não deve se mostrar exagerado. De acordo a tal percepção, qualquer fórum deliberativo, decisório ou não, precisará selecionar quais razões se mostram aceitáveis ou distinguir as razões públicas das não-públicas. (MENDES, 2013) 


\section{Entre razões jurídicas e razões não-jurídicas}

Para Mendes, como se vê, democracia pressupõe uma formalidade na argumentação política e no âmbito parlamentar isto não seria diferente. Diante deste quadro, se mostra errado, portanto, ler positivismo ou nãopositivismo como algo excluindo a formalidade ou o caráter deliberativo do direito. A controvérsia não é 'se', mas 'como' o direito é deliberativo, uma questão de grau e não de tipo, diferindo sobre o que seria apropriado classificar como razão jurídica ou não-jurídica e o que seria controlável pelas diretrizes jurídicas. Segundo o autor, alguns adotam uma abordagem mais expansiva da formalidade do direito permitindo maior penetração às premissas subterrâneas das regras. Outros, por sua vez, restringem este escopo formal. (MENDES, 2013)

Para Mendes, ainda haveria outra forma de ventilar dúvidas sobre o caráter deliberativo do direito, ou mais precisamente, da adjudicação. Isso decorre do lado institucional: as cortes colegiadas promovem o encontro de magistrados que precisam tomar uma decisão conjunta. $\mathrm{Na}$ percepção do autor, existem vários aparatos processuais os quais permitem a um órgão colegiado chegar à uma decisão coletiva. A questão seria a deliberação integrar este aparato e assim regular o comportamento judicial informando as expectativas sobre a adjudicação colegiada. (MENDES, 2013)

Finalmente, se um regime político prestigia o status igualitário de seus membros, o compromisso político formal ou informal deve respeitar os padrões prescritos. Este seria o conceito normativo de legitimidade política a ser assumido como "uma interação interpessoal regulada por parâmetros reconhecendo a igual classificação de cada indivíduo". Mais precisamente, exibir consideração e simpatia pelo ponto de vista alheio. É por isso que as principais afirmações serão direcionadas à esfera pública informal ou às instituições formais participativas. Para o autor, em ambas configurações, a deliberação genuína incorpora uma conquista cívica a qual, independente de sua consequência, será politicamente significativa. (MENDES, 2013) 


\subsubsection{O conceito de legitimidade política}

Segundo Mendes, no momento em que um subgrupo de cidadãos se torna decisor, lhes é concedida autoridade e se tornam segregados dentro de um corpo aristocrático, como as cortes, os órgãos administrativos ou os parlamentos eleitos. ${ }^{34}$ Para o autor, o reconhecimento do status igual dos cidadãos não resulta, por si só, de uma deliberação entre juízes. Como é criada uma distinção entre órgãos de governo e cidadãos governados, entre órgãos formais e a esfera pública informal, um elemento aristocrático indelével estará inserido em um regime político e esta seria a "Face de Jano" dos próprios parlamentos. ${ }^{35}$ (MENDES, 2013)

Desse modo, para o autor, o valor intrínseco ocasional por trás da maneira como decisores interagem se mostra desbotado, pois este elemento intrínseco não pode ser transferido em bloco com a mesma força autônoma que em parlamentos. A distinção entre essas instituições desempenha uma função política contendo um compromisso predominantemente epistêmico. O fato de juízes deliberarem uns com os outros, portanto, não carregaria nada autonomamente louvável nesse sentido. (MENDES, 2013)

Na visão de Mendes, se não pelos resultados que possam suceder, a deliberação judicial estaria, numa perspectiva política, além de seu propósito. Por conseguinte, deve indicir o mesmo propósito na deliberação intrainstitucional. Juízes, ou qualquer outro decisor oficial, não deliberam e não deveriam deliberar por conta própria. Estes devem deliberar, sim, para encontrar o melhor resultado possível diante da respectiva tarefa decisória a qual lhes foi atribuída. Como juízes estão vinculados institucionalmente, o impulso de uma deliberação judicial se afirmaeá como predominantemente epistêmico. (MENDES, 2013)

\footnotetext{
${ }^{34}$ Sobre a distância entre as pessoas e as decisões determinantes do direito, Mendes recomenda WALUCHOW, Wil. A common law theory of judicial review: the living tree. Cambridge: Cambridge University Press, 2007. Sobre os "ius dicere", ver a obra de Piero Calamandrei (1935).

${ }^{35}$ Figura mítica da cultura romana simbolizando decisões e escolhas implicarem em renúncias.
} 


\section{Um casamento entre conjuntos de elementos}

Ou seja, para o autor, a plausibilidade da promessa epistêmica será a condição necessária para exigir a deliberação de juízes. Se, por sua vez, essa expectativa for realmente sólida, será possível resgatar, de forma condicional, seu valor intrínseco e uma vez que a deliberação aumente as chances de melhor decisão, praticá-la denotará consideração. A deliberação, portanto, seria valiosa mesmo quando juízes não cumprissem a promessa epistêmica. Uma vez aceita a deliberação ser provavelmente o meio mais plausível em se alcançar a melhor resposta, a mera tentativa terá um valor em si. Em função disso, segundo a concepção de Mendes, uma corte se baseará no casamento entre três elementos para se tornar deliberativa:

I - As razões independentes da deliberação;

- impessoalidade institucional;

- prudência política;

- multi-vocidade interpretativa; e

- probabilidade epistêmica.

II - Um órgão colegiado; e

III - As próprias promessas da deliberação.

- epistêmica;

- comunitária;

- psicológica; e

- educativa. 


\section{Escrutínio constitucional e estrutura institucional}

Para Mendes, o casamento acima ofereceria vantagens notáveis sobre todas as alternativas. Pode-se ainda dizer, por conta do argumento, que se as razões independentes da deliberação não sejam plausíveis, um arranjo primus inter pares poderia igualmente responder aos reclames da deliberação. ${ }^{36}$ Na percepção do autor, esta configuração poderia manter os aspectos positivos da deliberação sem diluir a autoridade e um plenário altamente deliberativo, com membros liderados na figura de um presidente, por exemplo, também poderia se beneficiar da deliberação para tomar as decisões apropriadas. (MENDES, 2013)

Assim, para uma análise em relação ao escrutínio constitucional, é preciso considerar que a estrutura institucional de uma corte constitucional não será empregada no sentido técnico convencionado pela literatura, isto é, uma distinção relevante entre "supremas cortes" e "cortes constitucionais" stricto sensu. Para a tese do autor, as diferenças quanto ao tipo de controle de constitucionalidade (difuso e concreto em oposição a concentrado e abstrato), e como este se situa em relação ao sistema judiciário, não são triviais. ${ }^{37}$ No entanto, o núcleo de seu papel é coincidente e por isso o termo “cortes constitucionais" se conformará lato sensu. (MENDES, 2013)

\footnotetext{
${ }^{36}$ Expressão latina a qual indica maior dignidade entre os outros de mesmo nível ou ofício. As alternativas correspondem às "imagens políticas" encontradas no item 1.2.1, o qual aborda o propósito institucional de uma corte constitucional. Por sua vez, o arranjo acima se refere à configuração deliberativa de uma corte mostrar-se a melhor alternativa para alcançar o propósito epistêmico indicado. Por outro lado, cabe aainda mencionar a leitura de STRUCHINER, Noel e BRANDO, Marcelo. Como os juízes decidem os casos difíceis do direito? In: STRUCHINER, Noel e TAVARES, Rodrigo de Souza (orgs.). Novas fronteiras da teoria do direito: da filosofia moral à filosofia experimental. Rio de Janeiro: PoD: PUC-Rio, 2014, pp. 171- 219.

${ }^{37}$ Como enfatizamos, embora essas diferenças não sejam triviais, a abordagem de Mendes se atém a um mínimo denominador comum institucional, conforme estabelecemos no item 1.3.3 a seguir. Na literatura brasileira sobre o assunto, pode-se encontrar um amplo panorama destas diferenças em BRANDÃO, Rodrigo (org.). Cortes Constitucionais e Supremas Cortes. Salvador: Juspodivm, 2017. O livro mencionado, no entanto, não aborda o Supremo Tribunal Federal brasileiro.
} 


\subsubsection{As propriedades institucionais}

Como vimos, as diferenças institucionais podem exigir adaptações, mas não invalidam uma reivindicação normativa geral. Para Mendes, a sua definição seria mínima e com uma corte constitucional possuindo apenas três propriedades institucionais básicas:

I - Ser um pequeno órgão colegiado formado por membros não eleitos e, portanto, privados da certificação periódica e competitiva de autoridade. Em vez disso, estes são nomeados por intermédio de métodos políticos distintos; ${ }^{38}$

II - Não ter um motor próprio e ser tipificada pela inércia, pois os casos são trazidos por provocação externa e não por uma iniciativa interna as quais supõem estimular a condição de imparcialidade;

III - Ter o poder de desafiar, supervisionar e, em geral, anular atos dos parlamentos eleitos em nome da supremacia constitucional.

Segundo o autor, estes seriam os contornos institucionais os quais todas as cortes constitucionais compartilham. Tal definição, permanecendo ao nível de desenho institucional, tem um nível de generalidade o qual evade qualquer apego a um sistema específico. Feita esta ressalva, convém tratarmos da revisão judicial, seu principal objeto de litígio envolvendo a legitimidade política. (MENDES, 2013)

\footnotetext{
${ }^{38}$ Ver ROMANELLI, Sandro Luís Tomás Ballande. Suprema (in)dependência: mecanismos da relação entre governos e o Supremo Tribunal Federal. Tese de Doutorado em Direito. Curitiba: UFPR, 2016; e trabalhos de Newton Tavares Filho, tais como Democratização do processo de nomeação dos ministros do Supremo Tribunal Federal. Brasília: Biblioteca Digital da Câmara dos Deputados, 2006. Disponível em: http://bd.camara.gov.br/bd/handle/bdcamara/1596; entre outros.
} 


\section{Genealogia canônica da revisão judicial}

Em Mendes, o surgimento da revisão judicial e seu aprimoramento ao longo do tempo dramatizaram significativamente a tensão histórica entre as cortes e os parlamentos. Essa tensão ressoou na teoria constitucional e desencadeou novos tipos de perguntas inspiradas pelo ideal democrático. $\mathrm{Na}$ visão do autor, o que seria uma característica originalmente dos Estados Unidos da América tornou-se, ao final do século XX, uma multinacional pelo advento das cortes constitucionais e da judicialização da política nas democracias ocidentais. (MENDES, 2013)

Para Mendes, diante desta trajetória, a genealogia canônica da revisão judicial possuiria três importantes mestres: James Hamilton, ${ }^{39} \mathrm{o}$ qual anunciou os "anos de raciocínio" (rationale years) antes da revisão judicial; o Ministro-chefe John Marshall, ${ }^{40}$ o qual derivou esse poder do que entendia como uma lógica implícita da constituição; e Hans Kelsen, ${ }^{41}$ o qual teorizou profundamente sobre seu papel estrutural e inspirou a criação de um novo modelo de controle de constitucionalidade. (MENDES, 2013)

Segundo o autor, essa tríade de renomados autores se preocuparia com a institucionalização da supremacia constitucional, mas o núcleo de sua sugestão seria basicamente o mesmo: "a validade de uma norma jurídica depender de sua compatibilidade com a constituição e o poder judiciário ser encarregado de aplicar o direito, portanto, autorizado a desconsiderar as normas inconstitucionais”. (MENDES, 2013)

\footnotetext{
${ }^{39}$ Mendes cita a afirmação: "Nenhum ato legislativo, portanto, contrário à constituição pode ser válido. Negar isso seria afirmar que [...] os representantes das pessoas são superiores às próprias pessoas [...]. É muito mais racional supor que as cortes foram concebidas para serem um órgão intermediário entre as pessoas e a legislatura." (Hamilton, Madison e Jay, The Federalist n. 78, p. 397). Mendes também recomenda a leitura de Brutus, Carta XII, p. 507.

${ }^{40}$ Ver Marbury v. Madison, 5 U.S. 137 (1803). Caso paradigmático no cenário dos E.U.A.

${ }^{41} \mathrm{O}$ autor indica os trabalhos KELSEN, Hans. Wer soll der Hüter der Verfassung sein? Die Justiz, n. 6, 1931, p. 576-628; e NINO, Carlos Santiago. The constitution of deliberative democracy. New Haven: Yale University Press, 1996. Ver a coleção "Nómos Basileús" da editora Via Verita.
} 


\section{Cadeia de justificação entre demandas deliberativas}

$\mathrm{O}$ autor esclarece que, sem uma agência externa extraparlamentar, a supremacia constitucional não seria obtida e o parlamento estaria livre para alterar a constituição sob o pretexto formal da legislação ordinária. Segundo Mendes, esse debate elevou-se a um novo estágio: ${ }^{42}$ concordou-se sobre as cortes enfrentarem uma regulamentação mais firme em relação à entrega de razões, pois a separação de poderes englobaria vários tipos de responsabilidade, cada uma das quais ocupando pontos distintos de uma "cadeia de justificação". (MENDES, 2013)

Ou seja, quanto maior for a linha de delegação e mais distante uma autoridade estiver do processo eleitoral, maior será o seu dever em prover razões "a título de compensação". Em um extremo, uma carga deliberativa mais pesada compensaria seu deficit eleitoral ( $>$ deliberação interna). Em outro, o deficit deliberativo seria contrabalançado pela proximidade junto a população ( $>$ deliberação externa). Essas cargas variadas são inversamente correlacionadas aos regimes democráticos. (MENDES, 2013)

Para Mendes, esta concepção da responsabilidade seria derivada da chamada "teoria folclórica da democracia", a qual exige procedimentos. Assim, pode-se esperar que um sistema político-jurídico em bom estado de funcionamento exiba uma série de relações de responsabilidade as quais se revestem aproximadamente do político ao jurídico ou do arbitrário ou voluntário ao razoável ou deliberativo. (MENDES, 2013)

Dessa forma, haveria uma escala de demandas deliberativas decrescentes de acordo a quatro graus de separação das pessoas: cortes, órgãos públicos, legislaturas, e eleitores. A urna seria uma "zona livre de razão" e nesta fase apenas os números se mostrariam importantes. Dessa maneira, espera-se que cortes deliberem e são concedidos procedimentos compelindo à deliberação para garantir esta realização. (MENDES, 2013)

\footnotetext{
${ }^{42}$ Sobre este debate, ver SILVA, Virgílio Afonso da. O STF e o controle de constitucionalidade: diálogo, deliberação e razão pública. Revista de Direito Administrativo, n. 250, 2009.
} 


\subsubsection{Padrões deliberativos de autoridade judicial}

Dito de outra forma, pelo fato das cortes não terem acesso direto ao poder político, seriam formuladas para se apoiarem em razões. Segundo Mendes, essa distinção se mostrou útil e também lançou luz sobre funções e configurações separadas tornando mais evidente o reconhecimento de uma corte constitucional como "deliberadora". Para o autor, os juízes deliberam internamente enquanto se esforçam para atingir um assentamento singular, e também deliberam externamente ao exporem sua decisão ao público. A partir disso, dois padrões principais de cortes constitucionais são inferidos:

I - o Estadunidense, o qual representa um modelo centrado na deliberação externa, com pouco envolvimento presencial entre os magistrados e uma liberalidade para se expressar em múltiplas vozes individuais (seriatim); e

II - o Kelseniano, o qual valoriza a clareza, pois depois de travar deliberações sigilosas, na maioria dos casos, tende a se comunicar por intermédio de uma voz singular, institucionalizada (per curiam).

Segundo a tese de Mendes, um arquétipo seria externo (E.U.A.), enquanto o outro seria interno (Kelsen), mas apesar das desigualdades entre as cortes, todas, a seu modo, manteriam o "caráter deliberativo exemplar" segundo John Rawls. Assim, o padrão Kelseniano, no qual a autoridade da revisão judicial está concentrada exclusivamente em uma corte especial, exigiria mais unidade caso as cortes comuns possam aplicar decisões da corte constitucional. Já o padrão Estadunidense, caracterizado por uma autoridade difusa declarando a inconstitucionalidade no sistema judiciário, exigiria uma maior coordenação entre a corte e os magistrados inferiores. (MENDES, 2013) Estes padrões, por sua vez, importam ao STF. 


\section{Reformas institucionais e normas deliberativas}

Para o autor, dessa constatação surgem múltiplas vozes individuais as quais permitem a outros atores do sistema jurídico anteciparem ações da corte para identificarem quem é quem dentro da instituição e como cada membro se torna susceptível a decidir. ${ }^{43}$ Ao elucidar esses dois padrões, também surge uma avaliação crítica da corte estadunidense para que seus magistrados se comprometam e se esforcem a encontrar uma opinião a qual os demais tribunais possam endossar, além do apelo normativo a uma deliberação interna mais densa nas cortes kelsenianas. (MENDES, 2013)

Deste modo, Mendes sugere reformas necessárias para galvanizar os magistrados a gastarem menos de seu tempo e esforço como indivíduos tentando influenciar públicos externos e se concentrarem em encontrar um meio-termo tal como fariam órgãos genuinamente deliberativos. Apesar de existirem aspectos positivos em opiniões múltiplas, incidem duas propostas para influenciar o comportamento político das cortes: (MENDES, 2013)

I - Uma reforma institucional a tornar as cortes menos partidárias mediante um novo modo de indicação e de mandato; ${ }^{44} \mathrm{e}$

II - a comunidade jurídica exigir dos juízes o cumprimento de normas deliberativas voltadas à busca do consenso e à ética do compromisso, além de uma contenção a respeito da exibição pública de idiossincrasias pessoais entre seus membros.

\footnotetext{
${ }^{43}$ Para Mendes, em parte isso seria necessário pelo fato da corte não ter o monopólio sobre a interpretação constitucional e, na maioria das vezes, atuar para regular o processo pelo qual a constituição é aplicada por outras cortes. Este papel de coordenação ou regulamentação obriga a corte a fazer o seu trabalho de forma pública ou transparente. Ver a seção 2.3 e a subseção 2.3.1.

${ }^{44}$ Veremos os instrumentos institucionais no segundo capítulo, na seção referente à uma das variáveis do modelo avaliativo de desempenho (2.2) sobre os instrumentos constitutivos (2.2.4).
} 


\subsubsection{Aspectos a serem explorados}

Conforme buscamos apresentar, importantes questões empíricas e normativas foram levantadas pela literatura levando nosso autor a se esforçar em relacionar a revisão judicial à deliberação. Desta forma, seu modelo avaliativo de desempenho deliberativo direcionado às cortes constitucionais explorará os aspectos teóricos fundamentais iniciados pela teoria e os quais necessitariam de maior refinamento. Estes 6 (seis) aspectos teóricos estão listados e descritos abaixo, conforme veremos a seguir.

$\begin{array}{ll}\mathbf{1}^{\mathbf{0}} & \text { decisão escrita deliberativa; } \\ \mathbf{2}^{\mathbf{o}} & \text { fases deliberativas; } \\ \mathbf{3}^{\text {o }} & \text { valores deliberativos; } \\ \mathbf{4}^{\text {o }} & \text { reformas deliberativas; } \\ \mathbf{5}^{\mathbf{0}} & \text { normas deliberativas; } \mathrm{e} \\ \mathbf{6}^{\mathbf{0}} & \text { medidas de desempenho deliberativo. }\end{array}$

$\mathbf{1}^{\mathbf{0}}$. Em Mendes, uma noção de deliberação externa ligada à uma forma de exibição pública (seriatim, por exemplo) falha em capturar como a substância da decisão pode ser importante sobre os prismas empírico e normativo. Segundo o autor, há maneiras de se argumentar que, mesmo se comunicadas no modo per curiam, as decisões incorporam, sensivelmente, desentendimentos e se envolvem de forma respeitosa a eles. Uma decisão seriatim, na percepção de Mendes, obteria uma pontuação menor a esse respeito se simplesmente evitasse a menor discussão externa. Por esse motivo, se propõe a noção de uma decisão escrita deliberativa para abordar esta preocupação normativa. Ao invés de uma negociação casual entre os elementos interno e externo, Mendes busca trabalhar sob a hipótese de fenômenos de reforço mútuo. (MENDES, 2013) 
$2^{\mathbf{0}}$. O autor afirma a noção de deliberação externa negligenciar etapas e práticas diferentes neste cenário político: a fase pré-decisória, onde a corte pode intensamente influenciar o debate público e administrar várias técnicas para receber aportes argumentativos (inputs), e a pós-decisória, onde a corte entrega seu produto até a próxima rodada de deliberações sobre a mesma questão (outputs). Segundo Mendes, a tarefa e o valor de cada momento, além das respectivas virtudes necessárias para realizá-las, não serão coincidentes. Para ele, a distinção entre as fases pré-decisória e pós-decisória não é trivial. Assim, equiparar ambos como "externo", ou simplesmente ignorar a primeira e destacar apenas a última, conduz à uma perda dos principais aspectos deliberativos. (MENDES, 2013)

$3^{\mathbf{0}}$. Na visão de Mendes, a noção de deliberação interna não fornece uma descrição compreensiva do que seria esperado segundo os valores de uniformidade, previsibilidade e coordenação demandados pelo Estado de direito. Em outras palavras, a deliberação interna seria valiosa somente em proveito de princípios formais convencionais, uma perspectiva parcial, pois haveriam mais benefícios na deliberação que um inteligível provimento de razão. ${ }^{45}$ A deliberação não trataria apenas do fornecimento de certeza. Para o autor, em um ambiente de reciprocidade, a inclinação em persuadir e ser persuadido, mesmo sem levar ao consenso, não se mostra menos importante mesmo quando o dissenso persistisse. (MENDES, 2013)

$4^{0}$. Em outra linha, ao considerar o desenho institucional, sua tese exige quórum legislativo qualificado no processo de indicação e mandato fixo. Essa reforma deliberativa aproximaria o modelo estadunidense ao kelseniano, pois a composição seria menos motivada pelo comportamento partidário. Para Mendes, apesar de cruciais, estes dispositivos ainda não esgotam o conjunto de incentivos a levarem uma corte a se tornar mais deliberativa, por isso continuam redutivos e estreitos. (MENDES, 2013)

\footnotetext{
${ }^{45}$ Segundo o autor, o 'provimento de razão' se relaciona à legitimidade, mas deixaria de captar a essência da deliberação em instituições não eleitas do regime democrático constitucional.
} 
$5^{\circ}$. Por esse motivo, esses dispositivos adicionam à sugestão de desenho institucional um apelo a normas deliberativas. Isto é, elaborar uma ética a qual reconheça a importância da deliberação, mas, no entanto, sem a confirmar devido a necessidade de comprovação empírica. Segundo o autor, atrás de uma exortação abstrata para se envolver no processo de persuasão, poderiam existir virtudes minuciosas as quais tornassem a deliberação uma tarefa mais discernível. (MENDES, 2013)

$6^{\circ}$. Finalmente, Mendes aponta a legitimidade política das cortes constitucionais estar de alguma forma ligada à sua qualidade deliberativa. Assim, uma vez que a deliberação se mostra um fenômeno flutuante, uma teoria deve ser capaz de medir diferentes graus de realização do ideal deliberativo. Dito de outra forma, seria necessário conceber medidas de desempenho deliberativo. Afinal, se uma corte constitucional estima se tornar deliberadora, e não apenas provedora de razão ou interlocutora, essas questões devem ser abordadas. Este é o ponto central. (MENDES, 2013)

Concluído o capítulo, abordamos a conceituação de nossa matriz de análise: a deliberação política (1.2). Dessa forma, reconhecemos os tipos de deliberadores, os tipos de deliberação e as fases deliberativas consistirem em elementos úteis para delinear a deliberação em instituições políticas. Como tratamos de cortes constitucionais, isto acarreta em especificidades sendo necessário elaborar um desenho institucional qualificado capaz de orientar este órgão colegiado e especializado em sua principal tarefa, a qual vimos: a realização de uma deliberação constitucional (1.3).

Dado este contexto institucional e a virtude decisória colegiada, as cortes precisarão reconhecer circunstâncias nas quais se vêem enredadas e se estabelecerem critérios para otimizar o propósito institucional acima. De modo a alcançar uma maior legitimidade política, portanto, estas serão as bases do modelo avaliativo de desempenho deliberativo as quais moldarão uma corte deliberativa. Então, como funcionam este modelo avaliativo e seu respectivo tipo ideal? O que esses objetos podem apontar sobre o STF? 


\section{UM MODELO AVALIATIVO DE DESEMPENHO}

\section{Justificando a revisão judicial}

Como atestado, o tema em análise propõe a justificação da revisão judicial como uma propriedade institucional. Para o autor, de acordo a introdução, as cortes constitucionais foram louvadas a fóruns deliberativos únicos sem a teoria desenvolver uma investigação mais refinada sobre esta propriedade e as suas respectivas implicações práticas. (MENDES, 2013)

$\mathrm{Na}$ análise teórica feita pelo autor, graças ao isolamento da política eleitoral e devido à expectativa da decisão judicial ser fundamentada em razões públicas, uma corte constitucional teria melhores condições em proteger direitos e fazer cumprir a Constituição. Segundo Mendes, no entanto, tais atributos não seriam apenas características de seu contexto institucional, mas a ausência de eleições e os encargos argumentativos devidos, por si só, não se mostram capazes de revelar a efetiva contribuição judicial de uma corte ao processo constitucional. (MENDES, 2013)

Por esse motivo, a teoria normativa apenas concederia legitimidade à revisão judicial mediante um desempenho deliberativo singular. Logo, o problema fundamental seria saber o que pedir e o que esperar de uma corte ideal. Para Mendes, muito além do apelo superficial à justificativas públicas fundamentadas no princípio constitucional, é necessário abordar as práticas que devem preceder e os valores que devem orientar o ideal de uma corte constitucional. Neste caso, uma corte deliberativa. ${ }^{46}$ (MENDES, 2013)

\footnotetext{
${ }^{46}$ No dia 08/11/2018, Conrado Hübner Mendes (USP) participou do painel "STF em debate" pelo V CITI (Congresso Internacional de Teoria das Instituições), no Tribunal de Justiça do Rio de Janeiro, apresentando a exposição "O STF na democracia brasileira: vanguarda ilusionista". Na ocasião, esteve ao lado das exposições de André Rufino do Vale (IDP), "A deliberação no STF: problemas atuais e propostas de aperfeiçoamento institucional", e de Diego Werneck Arguelhes (FGV-Rio), "A Corte Aberta e seus inimigos: uma defesa contingente de publicidade em deliberações judiciais". Esta mesa foi presidida por Igor de Lazari Barbosa Carneiro (UFRJ), autor de "Decisões colegiadas e desenho institucional", publicado pela LMJ Mundo Jurídico em 2018.
} 


\section{Preenchendo uma lacuna teórica}

Como vimos na lógica de Mendes, se a deliberação política é algo benéfico, e por esse motivo uma corte constitucional deve ser deliberativa, então é necessário investigar os componentes dessa tentativa. Na visão do autor, como a deliberação seria uma realização caso a caso e não um reflexo automático de aspectos teóricos deficientes, as lacunas teóricas poderiam ser colmatadas por um modelo avaliativo de desempenho deliberativo. Dessa forma, Mendes busca justificar o lugar da deliberação no sistema geral de tomada de decisões coletivas, mas sem insinuar a superioridade constitucional entre as principais instituições políticas: parlamento e corte.

A partir dessa ideia, o modelo criado pelo autor destacará as potenciais vulnerabilidades e vigores de uma corte constitucional. Mendes crê na capacidade desse tipo de instituição contribuir ao raciocínio judicial baseado em valores os quais suportam os dilemas constitucionais de uma comunidade democrática. Nesse limite, diante de uma intricada trama de personagens, o autor elabora sobre o sentido de uma corte deliberativa.

$\mathrm{Na}$ tese de Mendes, devido às variações situadas no contexto institucional, 'como' e 'quando' as cortes podem deliberar são perguntas sem uma resposta em abstrato. Afinal, seu contexto institucional é moldado por uma série de variáveis jurídicas, políticas e culturais. E é partindo dessa premissa que o modelo prescreve padrões normativos sobre o que se mostra mais atraente e aceitável a esse tipo de instituição política perseguir em meio as mais diferentes democracias constitucionais, como a brasileira.

Os padrões normativos prescritos pela tese do autor correspondem às competências deliberativas de cortes constitucionais. Ao estabelecer o ideal de uma corte deliberativa, portanto, Mendes avançará sobre um parâmetro comparativo o qual possibilite avaliar o desempenho deliberativo de uma corte constitucional do mundo real: o STF. Vejamos então as linhas mestras do modelo e esboçar sua possibilidade de aplicação prática. 


\section{As variáveis e a probabilidade de desempenho}

A espinha dorsal do modelo avaliativo estrutura-se sobre três níveis interrelacionados os quais correspondem às três variáveis de desempenho:

$1^{\circ}$ nível .............................. "Principal significado"
$2^{\circ}$ nível .................................. "Facilitadores"
$3^{\circ}$ nível ..................................... "Delimitadores"

O primeiro nível fornece ferramentas conceituais para se detectar o conjunto básico de competências deliberativas decorrentes da específica configuração de uma corte constitucional. Assim, localiza quem pode ser considerado um participante e especifica quem detém o poder de tomar decisões. Correspondendo ao comportamento institucional imediatamente observável de uma corte constitucional, também identifica fases e tarefas desse processo. Isto é, o seu propósito institucional. (MENDES, 2013)

Já o segundo nível indica as perspectivas e elucida as causalidades da deliberação. Corresponde aos instrumentos institucionais capazes de desencadear e galvanizar, ou mesmo dificultar e desencorajar a deliberação. Fornece informações sobre o que se esconde por trás do primeiro nível e se baseia na suposição do comportamento institucional se dar na fricção entre os incentivos e as mentalidades institucionais. (MENDES, 2013)

Para Mendes, se cortes devem ser deliberativas, procedimentos e virtudes também devem ser apreciados, pois não se explica o desempenho de uma instituição sem a presença desses elementos. Segundo o autor, as maneiras como a qualidade da deliberação e os instrumentos institucionais se interrelacionam na prática são difíceis de formalizar, e muito embora se constituam em suas condições básicas, a mera existência de instrumentos favoráveis não garante um desempenho deliberativo. (MENDES, 2013) 
Após as questões de propósito, mentalidade e arquitetura, por fim incidiriam as temáticas relativas aos limites institucionais. Ao ditar os tipos de razões públicas aceitáveis, o terceiro nível delineia sobre o que uma corte deve deliberar. Para Mendes, estas razões seriam derivadas de um conceito mínimo de argumentação constitucional, como na proposta de Robert Alexy acerca do chamado "constitucionalismo discursivo". Dessa forma, esta variável será capaz de mapear os dilemas políticos para as decisões da corte serem aceitas e efetivamente aplicadas. (MENDES, 2013)

Segundo a tese de Mendes, todas as instituições políticas de uma democracia constitucional se veem limitadas por diretrizes normativas do direito, mas também pelo manejo de forças políticas. Assim, o terceiro nível poderia atuar tanto no papel explicativo, permitindo avaliar o potencial deliberativo, quanto no papel prescritivo, ao instituir o que deve ser a substância da deliberação. Esta categoria, portanto, ajudaria a indicar a probabilidade da deliberação em si. (MENDES, 2013)

Sob esses termos, como pontuado em nossa introdução, Mendes afirmará ser mais provável um desempenho deliberativo elevado quando uma corte se deparar com um caso concreto o qual toca em questões de direito altamente controversas e o qual enfrenta obstáculos políticos para uma decisão efetiva (casos dificeis). Por outro lado, se o caso se encontrar relacionado a questões de direito razoavelmente resolvidas e levantar uma obstrução política previsível, um baixo desempenho deliberativo não será inesperado (casos fáceis), vide o quadro abaixo. (MENDES, 2013)

\section{Probabilidade de desempenho}

\begin{tabular}{cccc} 
casos & \multicolumn{2}{c}{ "delimitadores" } & probabilidade \\
fáceis & {$[<$ controvérsia $]$} & {$[>$ obstáculo $]$} & baixa \\
difíceis & {$[>$ controvérsia $]$} & {$[<$ obstáculo $]$} & alta
\end{tabular}




\section{A relação entre as variáveis}

Como percebemos, a deliberação se vincula a regras específicas pressupondo um perímetro substantivo fora do qual se encontrará aquém do limiar deliberativo. Ao mesmo tempo, a deliberação também pressupõe uma sensibilidade política sem a qual se tornará arriscada, inoportuna ou inócua. Desse modo, segundo o autor, sem notar como os "delimitadores" moldam o evento deliberativo, o "principal significado" poderia originar uma fachada de deliberações. (MENDES, 2013)

O modelo proposto por Mendes, portanto, buscará verificar se uma corte constitucional é deliberativa pressupondo um exame de conteúdo e de circunstâncias específicas sob seu contexto decisório. Assim, como os três níveis se interrelacionam, o desempenho deliberativo será a consequência da interação entre as variáveis "facilitadores" ( $2^{\circ}$ nível) e "delimitadores" ( $3^{\circ}$ nível), e tal interação será relativa ao "principal significado" ( $1^{\circ}$ nível):

\section{"Principal significado"}

Padrões deliberativos tarefas (objetivos)

"Facilitadores"

Traços éticos práticas e virtudes

Instrumentos institucionais dispositivos e constitutivos

"Delimitadores"

Substância jurídica contexto (razões)

Cenário político circunstâncias (estratégias) 
Diante deste esquema, se considerarmos o "principal significado" unido aos "delimitadores" como a realidade do desempenho deliberativo, a atitude dos "facilitadores" corresponderá à sua potencialidade. Desta maneira, segundo o modelo avaliativo, as categorias "principal significado" e "delimitadores" ajudam a avaliar se o resultado produzido pela instituição é deliberativo, enquanto a categoria dos "facilitadores" revela o provável conjunto de agentes casuais correlativos a este resultado. (MENDES, 2013) Esta definição permitirá traçar o seguinte quadro de exame:

\section{Quadro de Exame}

Realidade de desempenho "Principal significado" + "Delimitadores" Potencialidade de desempenho ... "Facilitadores"

Agentes resultantes relativos "Principal significado" + "Delimitadores" Agentes causais correlativos "Facilitadores"

O quadro, portanto, possui uma importância fundamental ao modelo por indicar suas perspectivas de análise - realidade e potencialidade - e também por apontar os componentes de cada uma dessas perspectivas agentes resultantes e agentes causais. A reunião desses quatro elementos configura-se na relação basilar entre os três níveis do modelo de Mendes.

Após essa colocação, tentaremos elaborar um roteiro de análise capaz de facilitar ainda mais a compreensão do leitor acerca do modelo. Esta elaboração se revela como um protótipo de análise capaz de avaliar empiricamente o desempenho de cortes constitucionais no mundo real, como no caso do STF. Vejamos então uma possível estrutura de análise. 


\section{Elaborado uma análise institucional}

Diante de nossa introdução, já conhecemos o pressuposto teórico da deliberação ser uma realização elaborada caso a caso. Partindo desse ponto, apresentaremos agora o exemplo de um caso genérico, relativo à uma corte constitucional em abstrato, para visualizarmos esta estrutura de análise.

\section{Ex.:}

"Caso X pela Corte Y".

\section{Realidade do desempenho da Corte $\mathrm{Y}$ no Caso $\mathrm{X}$}

Agente resultante tarefas deliberativas "Principal"

Agente resultante razões jurídicas "Delimitadores"

Agente resultante estratégias políticas "Delimitadores"

\section{Potencialidade do desempenho da Corte $\mathrm{Y}$ no Caso $\mathrm{X}$}

Agente causal práticas deliberativas "Facilitadores"

Agente causal virtudes deliberativas "Facilitadores"

Agente causal instrumentos dispositivos "Facilitadores" Agente causal instrumentos constitutivos "Facilitadores"

Ao esquadrinhar essas perspectivas e seus respectivos componentes, abrimos a possibilidade de aplicação dos padrões normativos de Mendes. Com efeito, esses padrões correspondem às tarefas oriundas de uma corte constitucional ideal. Ao assumirem a forma de um questionário elementar, os respectivos padrões normativos de desempenho estarão dispostos sob um sistema trifásico e precisarão responder a três perguntas básicas: 


\section{Questionário}

1'. Na fase pré-decisória do Caso $X$, a Corte $Y$ foi capaz de maximizar os argumentos de interlocutores durante a contestação pública?

$2^{\mathrm{a}}$. Na fase decisória do Caso $\mathrm{X}$, a Corte $\mathrm{Y}$ foi capaz de energizar os decisores em um processo de interação colegiada?

$3^{a}$. Na fase pós-decisória do Caso $X$, a Corte $Y$ foi capaz de redigir uma decisão escrita deliberativa direcionada a comunidade de interlocutores?

Para responder a esses questionamentos, o passo seguinte seria verificar o cumprimento desses padrões normativos (contestação pública, interação colegiada e decisão escrita deliberativa) ao inspecionar o modo de interação predominante entre os participantes de cada uma das três fases deliberativas (pré-decisória, decisória e pós-decisória). Esses modos de interação seriam cambiáveis e também os seus participantes em cada fase. O quadro abaixo buscará elencar os elementos desse jogo interativo no qual mergulharemos em maiores detalhes a partir da próxima seção (2.1).

Fase Modo de interação
1. Pré-decisória

2. Decisória face-a-face por escrito face-a-face

3. Pós-decisória
Participantes Interlocutores e Decisores Decisores Decisores e Interlocutores 


\section{Edificando o modelo avaliativo de desempenho}

De acordo a estruturação proposta, salientamos que os padrões normativos listados no parágrafo anterior merecerão um exame apropriado de acordo a indicadores personalizados a serem apresentados ao longo deste capítulo. Cada um dos indicadores proporcionará uma avaliação específica para determinar a qualidade do desempenho deliberativo em uma corte constitucional, ou seja, verificarem o quanto uma corte é deliberativa.

Feitas todas essas considerações, estabelecemos uma espinha dorsal assentada sobre três níveis de desempenho, mas para inspecionar os modos de interação, precisamos estruturar as engrenagens do modelo de modo a facilitar sua apreensão. Abaixo temos um panorama de todos os principais componentes a serem abordados. Este esquema sublinha os principais segmentos do modelo a ser explorado nas próximas seções. Ao cumprir uma função de guia, precederá cada um dos três níveis de desempenho: "principal significado" (2.1); "facilitadores" (2.2); e "delimitadores" (2.3).

\section{Estruturação do modelo avaliativo}

Primeiro nível $=$ Fases + Capacidades + Tarefas
Segundo nível $=$ Práticas + Virtudes + Instrumentos
Terceiro nível $=$ Contexto + Circunstâncias

Assim, cada seção conterá os objetos agrupados no roteiro de análise: os agentes resultantes (tarefas, razões e estratégias) e também os agentes causais (práticas, virtudes e instrumentos) relativos ao desempenho deliberativo. Visando a aplicação prática, pretendemos descrever o modelo de Mendes da forma mais dinâmica possível. Passemos ao primeiro nível. 


\subsection{O principal significado do desempenho deliberativo}

\subsubsection{As fases deliberativas}

Como ventilado, um sistema trifásico se manifestará sob três fases consecutivas e igualmente distintas. Na ótica do autor, cada uma dessas fases corresponde à uma tarefa específica e seu esforço geral é o propósito institucional de uma corte ao exercer suas competências deliberativas.

Fases

Pré-decisória

Decisória

Pós-decisória
Tarefas

contestação pública

interação colegiada

decisão escrita deliberativa

Segundo Mendes, essas três fases correspondem aos momentos em que o desempenho deliberativo poderá ser discernido e avaliado, como dito, são os segmentos de um mesmo esforço geral. O modelo isola essas tarefas para diagnosticar e avaliar os diversos tipos de problemas e de realizações correspondentes às instâncias da deliberação. Assim, a corte poderá ser deliberativa em uma dessas fases, mas não em outra, muito embora o pressuposto do autor seja uma corte constitucional de tipo ideal se tornar exemplar nas três fases mediante as três tarefas. (MENDES, 2013)

Para Mendes, uma corte deliberativa lança luz sobre essas tarefas sem nenhuma hierarquia entre elas, mas as várias circunstâncias poderão demanda-las e justifica-las em diferentes escalas ou intensidades. Assim, as hipóteses relacionando empiricamente as três fases poderão ser ensaiadas e testadas em várias cortes constitucionais, como o STF. (MENDES, 2013) 
Dito isto, as sinergias e compensações entre as respectivas tarefas de contestação pública (fase pré-decisória), interação colegiada (fase decisória) e decisão escrita deliberativa (fase pós-decisória) poderão ser reveladas e ajudarem a construir uma hipótese sensível à jurisdição de cada corte constitucional. No modelo de Mendes, cabe frisar, a distinção entre essas fases se encaixa no processo contínuo entre as sessões de audiência, as reuniões de conferência e a elaboração da decisão na Suprema Corte dos Estados Unidos da América, seu referencial. (MENDES, 2013)

Para compreendermos a atividade institucional de uma corte e seu papel no mosaico de democracias contemporâneas, portanto, é necessário considerar os resultados obtidos no desempenho da respectiva atividade nas diferentes democracias. ${ }^{47}$ Assim, ao analisar a adequação da arquitetura desta instituição à esta atividade, para além de sua idealização, busca-se perceber a influência dos mecanismos existentes para desempenhar esta atividade. Nesses termos, fases permitem mensurar não apenas a qualidade deliberativa, mas também a qualidade da adjudicação nestas democracias. ${ }^{48}$

A qualidade da adjudicação, contudo, pressupõe uma qualidade de participação. Afinal, quem são os participantes desse sistema deliberativo? Segundo a tese de Mendes, seriam os “deliberadores". Então, precisamos conhecer esta categoria para observar suaas interações durante o processo deliberativo constitucional, especialmente no Supremo Tribunal Federal.

\footnotetext{
${ }^{47}$ Ver a obra VERMEULE, Adrian. Mechanisms of Democracy: Institutional Design Writ Small. Cambridge, MA: Oxford University Press, 2007. A questão sobre “atividade institucional”.

${ }^{48}$ Sobre a avaliação da qualidade da adjudicação em cortes constitucionais, recomendamos o artigo "Como avaliar a performance das Cortes Constitucionais?”, de Rafael Bezerra para a mídia eletrônica JOTA, publicado em 13 de abril de 2016 e disponível em: https://jota.info/artigos/comoavaliar-performance-das-cortes-constitucionais-13042016. O autor compara, de modo sintético, o que entende por "perfil de avaliação da adjudicação" em três países, entre eles Brasil e E.U.A.. No caso brasileiro, mencionando a Exposição de Motivos da E.C. 45/2004, conhecida como "Reforma do Poder Judiciário"; a atuação do C.N.J.; e o plano estratégico da corte, "STF - rumo a 2020", o autor advoga pela busca de uma "saída institucional", a partir de "experiências exitosas observadas em outros países", a qual possibilite uma "maior interação entre a Corte e a sociedade civil".
} 


\section{Os deliberadores}

Pela definição de Mendes, decisores seriam os julgadores do caso e os interlocutores seriam os representantes e representados no caso. Estas categorias formam tipos relevantes de "deliberadores". Os interlocutores forneceriam aportes argumentativos - os inputs - para a produção de uma decisão judicial por parte dos decisores - os outputs. Nesse limite, interlocutores poderão influenciar e persuadir, mas não poderão decidir, isto caberia apenas aos decisores. (MENDES, 2013)

Fases

1. Pré-decisória

2. Decisória

3. Pós-decisória
Deliberadores

Interlocutores $\quad \mathrm{x}$ Decisores

Decisores $\quad x \quad$ Decisores

Decisores $\quad x \quad$ Interlocutores

O quadro acima reforça a relação entre os "deliberadores" em cada uma das três fases. Logo, para Mendes, interlocutores configuram uma comunidade compreendida por todos os atores sociais os quais, formal ou informalmente, endereçam argumentos à corte. Estes expressam as posições públicas sobre os casos a serem decididos. (MENDES, 2013)

Segundo o autor, a comunidade de interlocutores poderá se dividir em interlocutores formais, os quais envolvem todas as partes qualificadas e com direito a participar no caso constitucional; e interlocutores informais, os quais participam por meio de várias mídias comunicativas na tentativa de exercer uma influência indireta sobre a corte. (MENDES, 2013) Vejamos essas duas modalidades em termos de esferas públicas. 


\section{As esferas públicas}

Como atestamos, a comunidade de interlocutores se desdobrará em dois elementos importantes aos decisores de uma corte deliberativa. Como exposto no quadro abaixo, os decisores devem estar atentos a essas duas modalidades nas tarefas deliberativas almejadas em cada uma das três fases.

\section{Comunidade de interlocutores}

Interlocutores formais as partes Esfera pública formal Interlocutores informais os demais Esfera pública informal

A partir deste quadro, o autor declara se tornar menos difícil ilustrar a gravidade moral da deliberação nas fases pré e pós-decisória, pois uma corte constitucional interage não apenas com os litigantes da esfera pública formal, mas também com todos interlocutores da esfera pública informal. Segundo Mendes, uma corte deliberativa atuaria como um catalisador de deliberações externas por trabalhar como um fórum de contestação aberto e acessível, algo valioso à concepção de público. (MENDES, 2013)

Diante deste propósito, o autor afirmará o valor da corte em se tornar uma instituição na qual o imperativo moral de igual respeito não seja derivado do direito eleitoral, mas sim do direito a ser ouvido e receber uma resposta rigorosamente digna. Ao mesmo tempo, em meio às categorias diacrônicas - decisores e interlocutores, Mendes também mencionará, como uma tipologia importante para a compreensão do sistema trifásico, as noções de deliberação interna e externa. (MENDES, 2013) 


\section{O sistema trifásico}

Segundo a tipologia do autor, a deliberação interna corresponderia à fase decisória (interação colegiada); a deliberação externa à fase pósdecisória (decisão escrita); e a fase pré-decisória (contestação pública), entretanto, ficaria obscurecida. (MENDES, 2013)

\begin{tabular}{lcc}
\multicolumn{1}{c}{ Fase } & Tipo de deliberação & Tarefa \\
1. Pré-decisória & $X$ & contestação pública \\
2. Decisória & Interna & interação colegiada \\
3. Pós-decisória & Externa & decisão escrita deliberativa
\end{tabular}

Em linhas gerais, como acabamos de nos certificar, as três tarefas básicas de uma corte deliberativa seriam promover a contestação pública; favorecer a interação colegiada; e também elaborar uma decisão escrita deliberativa. A seguir, apresentaremos uma decomposição dos valores deliberativos traduzidos nas promessas exigidas por essas três tarefas em relação aos membros de uma corte constitucional, os seus decisores.

Todas essas promessas corresponderão às qualidades deliberativas imbricadas no sistema trifásico. Com efeito, envolvem as promessas: a) epistêmica; b) comunitária; c) psicológica; e d) educativa. ${ }^{49}$ Ou seja, as capacidades deliberativas de cada uma dessas fases e de suas respectivas tarefas para alcançar o tipo ideal de corte constitucional.

\footnotetext{
${ }^{49}$ Esta função pedagógica seria trabalhada por Bickel, Dworkin e Rawls. Ver também STONESWEET, Alec. Governing With Judges: constitutional politics in Europe. Oxford: Oxford University Press, 2000. Sobre a questão educativa relacionada à participação política, recomendase PATEMAN, Carole. Participação e Teoria Democrática. Rio de Janeiro: Paz e Terra, 1992.
} 


\subsubsection{As capacidades deliberativas}

Segundo a proposta de Mendes, cortes constitucionais devem ser instituições deliberativas em um sentido rico, isto é, há mais a ganhar com elas, mas continua necessário divulgar porquê a deliberação, em questões constitucionais, se mostra excepcionalmente valiosa. (MENDES, 2013)

A tabela a seguir elenca as potenciais qualidades deliberativas das tarefas e das práticas decorrentes da deliberação. Entre fracas e fortes, cada uma das tarefas trará a capacidade deliberativa entre as razões instrumentais (competências) e as razões intrínsecas (respeitabilidade moral) pertinentes às três fases deliberativas: pré-decisória; decisória e pós-decisória.

\begin{tabular}{|c|c|c|}
\hline $\begin{array}{l}\text { Contestação } \\
\text { pública }\end{array}$ & $\begin{array}{l}\text { Interação } \\
\text { colegiada }\end{array}$ & $\begin{array}{c}\text { Decisão escrita } \\
\text { deliberativa }\end{array}$ \\
\hline epistêmica fraca & epistêmica forte & epistêmica forte \\
\hline- & $\begin{array}{l}\text { comunitária } \\
\text { (interna) }\end{array}$ & $\begin{array}{c}\text { comunitária } \\
\text { (externa) }\end{array}$ \\
\hline psicológica forte & psicológica fraca & psicológica forte \\
\hline educativa forte & educativa fraca & educativa forte \\
\hline intrínseca forte & intrínseca fraca & intrínseca forte \\
\hline
\end{tabular}

Para o autor, vale dizer, esta compartimentação não sugere um processo descontínuo com características estreitas e segmentadas. Logo, as características acima ressaltam os diferentes caminhos e graus em que os valores e as promessas de deliberação estarão em jogo no decorrer de todo o processo decisório. (MENDES, 2013) A seguir, pretendemos abordar sinteticamente todas as promessas deliberativas e sua relação às tarefas propostas por Mendes. 


\section{a) promessa epistêmica}

Segundo o autor, a medida em que há um objetivo epistêmico no que as cortes fazem, seu propósito institucional poderá ser identificado ao longo das três fases decisórias. Para Mendes, uma contestação pública contribuiria para a multiplicação de pontos de vista sobre uma certa controvérsia, podendo, no mínimo, ser uma forte prática sob a coleta de informações. (MENDES, 2013)

Em sua visão, esta coleta seria consequente e indispensável ao potencial epistêmico da interação colegiada. $\mathrm{Na}$ fase decisória, diante da interação argumentativa em busca de uma opinião institucional, em vez de uma simples agregação não-deliberativa, seria mais provável se atingir uma decisão melhor afinada e também permitir uma construção transparente dos desentendimentos os quais remanesceram genuinamente entre decisores. Logo, inaugurar premissas, realizar um exercício criativo e perseguir a verdade serão mais prováveis resultarem de uma interação colegiada em vez das tradicionais técnicas de agregação. (MENDES, 2013)

Por fim, Mendes também compreende a entrega de uma decisão escrita deliberativa ter a função epistêmica de complementar os próximos casos com precedentes densamente redigidos. Sem tais precedentes, um caso futuro teria de reinaugurar a cadeia deliberativa, desperdiçando as realizações argumentativas e os progressos realizados em casos anteriores. Dessa maneira, desperdiçaria dividendos deliberativos os quais casos atuais poderão receber da acumulação de precedentes. (MENDES, 2013)

\section{b) promessa comunitária}

Para Mendes, o objetivo comunitário do consenso seria menos uma preocupação para a fase pré-decisória, a qual basicamente fornece aportes inputs - a uma próxima decisão. Assim, a contestação pública se inspira no propósito da persuasão. (MENDES, 2013) 
Vale frisar a inexistência de um compromisso especial para reduzir o desacordo no primeiro momento, pois seria um momento adversarial de litígio preocupado apenas em coletar argumentos e expor posições. Por outro lado, na interação colegiada, Mendes sustenta a responsabilidade na construção de uma decisão institucional des-personificada. A deliberação aqui sim seria uma maneira apropriada, mesmo que não a única concebível, em alcançar o consenso entre os decisores incidindo a necessidade de um compromisso. Por fim, a medida em que uma decisão escrita torna-se capaz de documentar a identidade institucional da deliberação interpessoal, tornase mais provável uma decisão não-deliberativa reduzir os desentendimentos entre o diferentes interlocutores da corte. (MENDES, 2013)

\section{c) promessa psicológica}

No raciocínio de Mendes, o objetivo psicológico, um sentimento de respeito instilado entre os participantes da deliberação, permitiria uma corte deliberativa concretizar seu trabalho por meio de uma contestação pública genuinamente porosa e de uma decisão escrita cuidadosamente redigida. Esse respeito intrainstitucional permitiria a corte permanecer colegiada e manter sua capacidade de deliberação. (MENDES, 2013)

\section{d) promessa educativa}

Finalmente, o objetivo educativo faz com que a deliberação seja um meio de educar os próprios deliberadores. A participação ativa no processo de contestação pública e no escrutínio da decisão judicial poderia educar os interlocutores nas habilidades argumentativas e nas atitudes morais exigidas pela deliberação além de os ilustrar no próprio assunto em questão. Quanto aos decisores, os quais deliberam de forma rotineira, o aprimoramento de suas habilidades seria uma expectativa frívola, mas a deliberação, ainda assim, poderia ser uma maneira peculiar de refinar seus conhecimentos sobre o tema relacionado ao caso. (MENDES, 2013) 


\subsubsection{As tarefas deliberativas}

Completando a descrição do primeiro nível do modelo, o "principal significado" do desempenho, veremos a configuração de cada uma das três tarefas as quais perfazem, segundo Mendes, o propósito institucional de uma corte constitucional mediante suas competências deliberativas.

\section{I - Promover uma contestação pública}

Para Mendes, a contestação pública seria motivada por um ator ou um grupo de atores políticos com o poder formal de apresentar um caso a corte constitucional por meio de recurso ou intervenção direta. Segundo o autor, o processo dialógico entre os interlocutores e decisores conteria potencialidades deliberativas a partir desse momento até chegarem a uma decisão. (MENDES, 2013)

$\mathrm{O}$ autor frisa que a qualidade desta tarefa pode variar de acordo com a relevância do caso e a forma como uma comunidade política se mobiliza para contribuir às questões coletivas endereçadas à corte. Para Mendes, portanto, como interlocutores compartilhariam a responsabilidade pelo desempenho geral desta fase, corresponderia ao envolvimento real de todos os atores interessados na apresentação de argumentos e a atenção da corte ao recebe-los publicamente. (MENDES, 2013)

Mendes acentuará o tipo ideal de uma corte deliberativa requerer sólidos instrumentos institucionais capazes de canalizar essas vozes, mas na falta de mecanismos formais, nada impede a corte estar atenta à pluralidade de posições captadas na esfera pública informal. Nessa concepção, seus mecanismos formais podem ser por escrito, compreendendo diferentes tipos de petições; e/ou face a face, incluindo audiências públicas e sessões de audiência. Assim, dependendo de quão flexíveis e versáteis sejam estes instrumentos para capturar os diversos tipos de argumentos e permitirem aos vários atores reivindicarem suas posições, esta tarefa poderá ser vista como um mecanismo de democracia participativa. (MENDES, 2013) 


\section{II - Implementar uma interação colegiada}

Esta segunda etapa se mostra a aspiração orientadora quanto à fase decisória. Segundo o autor, este seria o padrão adequado para disciplinar e avaliar o processo intramuros ocorrido entre os próprios decisores. Na visão de Mendes, em vez de olhar para fora a fim de coletar e testar argumentos os quais interlocutores podem forjar, decisores interagem uns com os outros para tomar uma decisão. A ideia é uma "assepsia institucional" ser assumida no momento em que decisores se reúnem para deliberar para que a interação colegiada se torne uma orientação plausível. (MENDES, 2013)

Para Mendes, o padrão de interação colegiada obrigaria decisores ouvirem e incorporarem razões de seus pares às suas, seja para aderirem ou divergirem. Segundo o autor, decisores se veem obrigados a ocultar ou suprimir o desacordo por estarem comprometidos à franca argumentação em busca da melhor resposta. Assim, se torna relevante uma corte tentar alcançar opiniões comuns, pois a deliberação não se limitaria apenas a um instrumento para fabricar o consenso, também serviria para tentar uma boa decisão independente de se alcançar a unanimidade. (MENDES, 2013)

Para o autor, uma corte deliberativa precisa ser permeável a uma ampla gama de argumentos impulsionados por várias fontes. Esta corte deve assimilar não só argumentos razoáveis os quais foram oficialmente apresentados por interlocutores formais, mas também os ventilados por interlocutores informais e aqueles empaticamente imaginados. Dessa maneira, a corte contrairia o ônus de representar e inspecionar posições atuais e vicárias em sua deliberação decisória. (MENDES, 2013)

Segundo Mendes, devido a habilidade da corte em ouvir a esfera pública informal e imaginar outros pontos de vista possíveis, seu modelo estabeleceria a compensação de eventuais deficits procedimentais quando interlocutores são impedidos de apresentarem formalmente suas razões ou quando há uma baixa capacidade da corte constitucional em ampliar seu estoque argumentativo. (MENDES, 2013) 


\section{III - Produzir uma decisão escrita deliberativa}

Por último, a decisão escrita deliberativa traduziria compromissos éticos da deliberação em uma peça escrita. Para isso, Mendes menciona que além de bem fundamentada, esta decisão teria o fardo de ser receptiva e legível pelo público. ${ }^{50}$ Avaliar se a decisão escrita é deliberativa, portanto, exigiria mais que o exercício pedestre em examinar se uma corte abordou todos os argumentos dos litigantes. (MENDES, 2013)

Nesse limite, Mendes adverte uma corte deliberativa contrair um dever em estar ciente de sua falibilidade; da inevitável continuidade da deliberação na esfera pública; e também sobre os possíveis casos futuros. Por esse motivo, a decisão escrita precisa transmitir esta atitude mediante uma retórica cuidadosa e laboriosa. Afinal, uma decisão precisa convidar a novas rodadas deliberativas mesmo consumando efeitos concretos no presente. (MENDES, 2013)

Na visão do autor, um dos pontos fundamentais da decisão escrita seria perseguir um estilo literário o qual evitasse tratar as partes como vencedores e perdedores de um concurso interpretativo. Nesse sentido, Mendes afirma que interlocutores seriam considerados membros de uma comunidade a qual continuará a falar sobre a controvérsia enquanto persistir um desacordo. Ou seja, pontos finais seriam reticentes. (MENDES, 2013)

Logo, o texto de uma decisão escrita deliberativa seria uma rearticulação da interação colegiada. Por isso Mendes sustentará este texto ter de tornar um processo complicado de argumentação interpessoal, seja face a face ou por escrito, em um discurso acessível. Ao também contrair esta finalidade, segundo o autor, o processo de redação resultaria em uma qualidade uniformizadora fundamental na função desempenhada pelas cortes constitucionais. (MENDES, 2013)

\footnotetext{
${ }^{50}$ Ver Sociolinguística interacional e Sociolinguística variacionista. Sobre estes campos da Linguística, mencionamos autores clássicos como Erving Goffman e William Labov. Neste sentido, chamamos atenção à categoria dos "socioletos" no que tange ao campo jurídico no Brasil.
} 
Para Mendes, nesse sentido, uma corte deliberativa deve garantir peso especial à autoria institucional, mas isso não precisa evitar a exibição de divergências internas a medida em que as circunstâncias recomendem. Por esse motivo, uma corte deliberativa não exibe publicamente qualquer tipo de divergência senão aquelas que resistem a interação colegiada, pois essas divergências, quando persistem, são realmente sérias e respeitáveis. (MENDES, 2013) Sobre este aspecto, incide dura crítica à atuação do STF.

Dessa forma, o autor estabelece uma decisão escrita deliberativa poder se manifestar em uma voz única ou uma voz múltipla, seja ela um per curiam, um seriatim puro, ou ficar em algum lugar no meio composto por uma opinião de maioria conjunta adicionadas as opiniões concorrentes ou divergentes. (MENDES, 2013) Eis uma forma de avaliar a corte brasileira.

\section{Voz única e voz múltipla}

Mendes aponta não existir uma causalidade imediata ou infalível entre a interação colegiada e uma única voz (per curiam), nem entre a falta de deliberação interna e a decisão de voz múltipla (seriatim). Para ele, a presença ou a ausência de deliberação na fase decisória não determina automaticamente esses formatos. Segundo o autor, uma interação colegiada de boa qualidade não pode ser facilmente presumida a partir de sua superfície formal e por isso tipos formais devem ser representados de uma outra maneira, conforme demonstramos nos graus - de 1 (um) a 4 (quatro) - exibidos abaixo. (MENDES, 2013)

\begin{tabular}{lcc}
\multicolumn{1}{c}{ Formatos } & seriatim & per curiam \\
Não-deliberativos & 1 & 2 \\
Deliberativos & 3 & 4
\end{tabular}


Em termos comparativos, o autor nos oferece a corte estadunidense como exemplo. Nela, as opiniões de decisores, tanto para a maioria quanto para a minoria, são quase sempre separadas. A menos que a opinião da maioria seja diluída em uma série de concorrências, geralmente há uma única opinião da corte unida por divergências ocasionais. Para Mendes, este movimento implicaria mais que o fato mecânico de uma economia no número de opiniões, envolveria tanto o compromisso quanto a demanda por uma deliberação colegiada capaz de suportar um ideal de múltiplos juízes agindo como uma entidade e não apenas como um agregado de opiniões individuais. (MENDES, 2013) Este último seria o caso do Supremo.

\section{Novos padrões de desempenho}

Com respeito ao desempenho deliberativo, ainda haveria uma diferença de grau ao longo de um continuum entre seriatim e per curiam, pois a corte pode alcançar, mesmo que de forma excepcional, um seriatim extremo. Por trás do formato, Mendes também nos alerta sobre a diferença qualitativa relacionada ao ethos interno da corte. Assim, como podemos ver na descrição abaixo e na sequência, certas nuances seriam ignoradas se anexarmos um seriatim à falta de deliberações. (MENDES, 2013)

\section{Padrões de baixo desempenho}
(1) seriatim não-deliberativo
voz múltipla
personificada
(2) per curiam não-deliberativo
voz única não se comunicam

\section{Padrões de alto desempenho}
(3) seriatim
deliberativo
voz múltipla
des-personificada
(4) per curiam
deliberativo
voz única se comunicam 


\section{Seriatim não-deliberativo (1)}

Como testemunhamos, um seriatim não-deliberativo (1) poderá simbolizar não apenas a falha, mas a absoluta falta de esforço em convergir, convergência essa a qual deve animar uma interação colegiada. Segundo Mendes, mesmo precedido por uma pequena comunicação informativa, este formato ficaria aquém do padrão normativo pré-estabelecido. Nessa concepção, rebaixa-se a instituição sob a sombra de seus membros individuais os quais tendem a se tornar personas públicas. Para o autor, os decisores acabam percebidos pelo que pensam pessoalmente e não pelo que são capazes de realizar enquanto um fórum colegiado. (MENDES, 2013)

Essa "indolência institucional", na opinião de Mendes, se torna repudiável por abdicar abertamente das promessas da deliberação. Mesmo que cada opinião fragmentada se esforce em argumentar da melhor maneira possível, se trivializa a dignidade dos dilemas constitucionais. Um seriatim não-deliberativo (1), portanto, é o arquétipo da personificação, pois seria composto por um mosaico de opiniões individuais as quais não conversam mutuamente entre si. Para o autor, a falta de comunicação entre estas opiniões se torna acima de tudo prejudicial ao Estado de direito por elas não fornecerem uma ratio decidendi ao caso em questão. (MENDES, 2013)

\section{Per curiam não-deliberativo (2)}

Segundo Mendes, um per curiam não-deliberativo (2) seria uma única opinião a qual não atende ao estilo literário eticamente preenchido. Dessa forma, mesmo sendo capaz de des-personificar e atender a algumas exigências do Estado de direito, tais como clareza e coordenação, seu formato não cumpriria os testes de capacidade de resposta e empatia. Para o autor, este formato se aproxima de uma exposição hermética e obscurantista das diretrizes jurídicas, mas pode ser adotado caso seja precedido por uma interação colegiada. (MENDES, 2013) 


\section{Seriatim deliberativo (3) e per curiam deliberativo (4)}

Finalmente, na concepção de Mendes, o per curiam deliberativo (4) é des-personificado em sentido bruto enquanto o seriatim deliberativo (3) contém múltiplas vozes as quais se comunicam entre si. Como visto, em vez de uma frágil "colcha-de-retalhos", as opiniões seriam costuradas de forma mais explícita. Os argumentos mútuos seriam enfrentados, as objeções seriam respondidas e seus pontos aprovados. Conforme veremos, o grau em que um seriatim deliberativo (3) pode ser des-personificado dependeria dos elementos relativos ao desenho institucional de uma corte. (MENDES, 2013)

\section{Propósito institucional: fases, capacidades e tarefas}

Exceto por um seriatim não-deliberativo (1), a escolha entre as outras opções formais poderia ser mais complexa devido às circunstâncias políticas em que a corte está enredada. Logo, mesmo um per curiam nãodeliberativo (2) pode ser recomendável quando as circunstâncias indiquem. Até aqui, o autor nos diz que todas as decisões proferidas por uma corte colegiada cairão em uma dessas quatro categorias. Para Mendes, uma corte deliberativa deve favorecer o terceiro (seriatim deliberativo) ou o quarto tipo (per curiam deliberativo) por ambos compartilharem o estilo apreciado por seu modelo. (MENDES, 2013) Vejamos o segundo nível.

\section{Estruturação do modelo avaliativo}

Primeiro nível $=$ Fases + Capacidades + Tarefas
Segundo nível $=$ Práticas + Virtudes + Instrumentos
Terceiro nível $=$ Contexto + Circunstâncias




\subsection{Os facilitadores do desempenho deliberativo}

\subsubsection{As práticas deliberativas}

A variável anterior descreveu o propósito de uma corte deliberativa, uma primeira parte dos agentes resultantes relativos à realidade de desempenho. Precisamos então conhecer os agentes causais correlativos para avaliarmos a sua potencialidade. Começaremos pela mentalidade institucional: as práticas e virtudes correlativas à cada tarefa deliberativa.

\section{Tarefas}

\section{Práticas}

I - Na contestação pública Em relação aos interlocutores:

i. Coletar argumentos

ii. Desafiar argumentos

iii. Mostrar abertura à argumentos

Il - Na interação colegiada Em relação aos colegas:

iv. Considerar todas as posições

v. Buscar a melhor resposta

vi. Buscar o consenso

III - Na decisão escrita

Em relação aos interlocutores:

vii. Utilizar estilo ético-literário

viii. Produzir discurso acessível

ix. Des-personificar a decisão 


\section{I - Práticas na contestação pública}

Segundo a proposta de Mendes, os interlocutores seriam incluídos por meio de canais argumentativos institucionais e extrainstitucionais oferecidos pela comunidade política. Nesse sentido, a corte deve orientar a fase pré-decisória com uma série de objetivos em mente e seu desempenho será julgado pelos seguintes padrões normativos: (i) coletar os argumentos de interlocutores; (ii) desafiar publicamente esses argumentos para os interlocutores terem a oportunidade de refiná-los; (iii) e mostrar abertura institucional aos atores capazes de agregar informações sobre o caso ao estoque de argumentos da corte constitucional. (MENDES, 2013)

\section{II - Práticas na interação colegiada ${ }^{51}$}

Nesta etapa, o autor estabelece como tripla a força motriz da interação colegiada. Para a corte equilibrar as demandas dessa fase, ela precisará alcançar, sempre que possível, um compromisso (iv) levando em conta todas as posições as quais se dispôs a coletar e conceber; (v) buscando a melhor resposta baseada em princípios; (vi) e almejando o consenso ou, caso este não surja, o dissenso mínimo. (MENDES, 2013)

\section{III - Práticas na decisão escrita deliberativa}

Finalmente, a decisão escrita deliberativa será caracterizada, acima de tudo, pelo seu estilo literário (vii). Como podemos aduzir, ela será produto de um esforço em lidar com todos os pontos de vista de um modo determinado (viii). Nesta fase de elaboração, segundo Mendes, se deve transformar a interação colegiada em uma decisão supra-individual para produzir um tipo especial de des-personificação transmitido apenas pela deliberação (ix). (MENDES, 2013)

\footnotetext{
${ }^{51}$ Como a investigação desse método analítico pretende se dirigir ao STF, nos aprofundaremos com maior rigor nas virtudes deliberativas conexas às outras duas tarefas: interação e decisão.
} 
Diante da mentalidade institucional, após condensarmos essas 9 (nove) práticas deliberativas, necessitamos reconhecer a segunda categoria de agentes causais correlativos: as virtudes deliberativas. Segundo o modelo avaliativo de Mendes, cada conjunto de práticas estará ligado a um conjunto de virtudes e este conformará uma ética capaz de incentivar o processo deliberativo em cortes constitucionais, tal qual o Supremo.

\subsubsection{As virtudes deliberativas}

No modelo desenvolvido, virtudes não seriam apenas um meio para a boa deliberação. Em Mendes, a prática de um conjunto específico de virtudes instanciaria a própria deliberação. Como podemos aduzir, essas virtudes serão um meio para os resultados estimados da deliberação e a correção desses resultados deve ser avaliada por um critério independente. Segundo o autor, a deliberação dependeria de atos francamente virtuosos, porém ainda não seriam o padrão apropriado para avaliarmos o que se mostra epistemologicamente correto a perseguir. (MENDES, 2013)

Na visão de Mendes, um conjunto de virtudes fornece a corte um senso de direção e, juntas, podem forjar uma cultura decisória a qual seria indispensável a credibilidade de uma corte deliberativa, significando sua própria respeitabilidade moral. Assim, o autor aponta que sem uma crença compartilhada sobre os potenciais benefícios da deliberação, o desempenho restará dificultado. (MENDES, 2013)

A seguir, desenvolvemos um diagrama elencando cada um dos conjuntos de práticas deliberativas e as virtudes correspondentes a eles. Esses conjuntos correspondentes se correlacionam a cada uma das 3 (três) tarefas deliberativas. O diagrama complementa o anterior e demarca nosso percurso nessa segunda subseção (2.2.2). Vejamos então quais são as 8 (oito) virtudes deliberativas ligadas a cada conjunto de práticas: 


\section{Práticas}

I - Na contestação pública

Coletar argumentos

Desafiar argumentos

Mostrar abertura a argumentos

\section{Virtudes}

Em relação aos interlocutores:

i. "Curiosidade respeitosa"
II - Na Interação colegiada

Considerar todas as posições

Buscar a melhor resposta

Buscar o consenso

\section{Em relação aos colegas:}

ii. "Colegialidade"

iii. "Modéstia cognitiva"

iv. "Ambição cognitiva"

v. "Empatia"

\section{III - Na decisão escrita}

Utilizar estilo ético-literário

Produzir discurso acessível

Des-personificar a decisão

\section{Em relação aos interlocutores:}

vi. "Capacidade de resposta"

vii. "Clareza"

viii. "Senso de falibilidade e provisoriedade"

Após o diagrama, convém mencionarmos que ao início de cada tarefa apresentaremos um quadro informativo trazendo um pequeno rol de micro-atitudes as quais decompõem cada uma dessas virtudes. Ao final de cada tarefa também faremos um encadeamento das virtudes relativas a cada uma das 3 (três) fases decisórias. Esperamos com isso tornar os indicadores mais perceptíveis, facilitando sua futura aplicação empírica no caso do STF. 


\section{I - Virtudes na contestação pública}

Segundo Mendes, a interação com interlocutores durante a fase pré-decisória seria essencial para o significado da deliberação. Em prol da independência e da imparcialidade, se tende a restringir as oportunidades de interação e se priorizar a passividade judicial. Por esse motivo, o autor sublinha o desenho institucional como uma possibilidade em nutrir ou prevenir o potencial da contestação pública. Essa tarefa se daria sob o pressuposto das outras variáveis não levarem a nenhum obstáculo contrário à ela. Assim, no que diz respeito ao papel dos decisores, a contestação pública se caracterizará pela "curiosidade respeitosa”. (MENDES, 2013)

\section{i. "Curiosidade respeitosa"}

a) desenvolver escuta ativa;

b) conter inclinações pré-deliberativas;

c) calibrar participação adequada;

d) orientar reunião de argumentos.

Mediante este quadro informativo, notamos o fato de uma corte constitucional deliberativa ter a capacidade em ouvir um grupo plural de interlocutores e ser porosa a vários tipos de argumentos externos. Para Mendes, portanto, seu tipo ideal deve maximizar pontos de vista os quais possam informar de modo rentável a deliberação subsequente, mas não no sentido de "quanto mais, melhor". Segundo o autor, esta advertência deve ser feita pois a instituição conferiria à uma ampla gama de interlocutores a oportunidade em falar e para isso precisa desenvolver um filtro qualitativo sobre quais argumentos são razoáveis para serem digeridos posteriormente. (MENDES, 2013) 
Dados os limites desta monografia, cabe enfatizarmos que embora reconheçamos a importância desta primeira fase - a pré-decisória -, e de sua respectiva tarefa - a contestação pública, não entraremos em maiores detalhes sobre cada um dos componentes desta virtude deliberativa em específico. $^{52}$

Dessa maneira, para compreendermos a mentalidade institucional envolvida na variável dos "facilitadores" do desempenho, basta dispormos das informações sintetizadas por hora. Logo, diante desta variável e da provável realidade deliberativa do STF, pretendemos concentrar nossos esforços na interação colegiada e na decisão escrita deliberativa, as quais se traduzirão em outras virtudes a serem visualizadas com maior riqueza de detalhes de agora em diante.

\footnotetext{
${ }^{52}$ No caso do STF, sobre esta fase especificamente, citamos o trabalho das pesquisadoras Marjorie Corrêa Marona e Marta Mendes da Rocha (Projeto Democracia Participativa/PRODEP-UFMG), "As audiências públicas do Supremo Tribunal Federal: ampliando sua legitimidade democrática?", publicado na Revista Teoria e Sociedade, n. 22, ano 1, jan./jun. 2014. Neste caso, recomenda-se ver o art. 13, incisos XVII e XVIII do RISTF; e também a L. 9.882 e a L. 9.868, ambas de 1999., acerca das audiências públicas em sede de controle concentrado. Ainda sobre este tema, também mencionamos LEITE, Carina Lellis Nicoll Simões. "As audiências públicas no STF: mero instrumento de legitimação formal?”. In: Daniel Sarmento (org.). Jurisdição Constitucional e Politica. Rio de Janeiro: Forense, 2015; além dos trabalhos de Carolina Vestana, tais como "Participação ou formalismo? O impacto das audiências públicas no Supremo Tribunal Federal Brasileiro". Dissertação de Mestrado Profissional em Poder Judiciário. Rio de Janeiro: FGV, 2010; e "Audiências públicas - Diagnóstico empírico sobre os limites da participação social". Revista Brasileira de Estduso Constitucionais, n. 24, ano 6, out./nov., 2012, pp. 973-1020. Em paralelo, na exposição de André Rufino do Vale no V CITI (ver nota 46), o advogado e ex-assessor do STF mencionou seu mais recente livro, "La deliberación en los Tribunales Constitucionales" (2017), para tratar de reformas estruturais de longo prazo, em especial, sobre "a qualidade das trocas argumentativas". Ao problematizar práticas anti-deliberativas na corte constitucional brasileira, Vale aborda a questão das audiências públicas e da sustentação oral enquanto um problema de "amplitude cognitiva e informativa", apontando a necessidade de se realizarem sustentações orais (hearings) antes da deliberação pública. Na ocasião, Vale também afirmou sua participação na Emenda Regimental (do RISTF) responsável pela "procedimentalidade das audiências públicas". Para o autor, esta medida oestimava ampliar a "circulação de informação" na corte brasileira.
} 


\section{II - Virtudes na interação colegiada}

Para Mendes, a interação colegiada seria um modo complexo de deliberação, mas apesar de orientada ao consenso não dependeria dele. Segundo o autor, os decisores contraem o ônus em alcançar uma solução ao caso constitucional e em converterem suas posições individuais numa posição institucional, mas sem suprimirem o próprio desacordo. Então, para cumprirem essas responsabilidades de forma deliberativa, decisores devem levar em consideração quatro virtudes, a primeira seria a "colegialidade". (MENDES, 2013) Esta virtude é fundamental para a perspectiva do STF.

\section{ii. "Colegialidade"}

e) objetivar unanimidade;

f) ter responsabilidade em interagir;

g) conter uso da composição;

h) encontrar meio-termo;

i) evitar divergências;

j) acreditar no bem supra-individual.

Inicialmente, Mendes relembra a errônea suposição sobre a "colegialidade" levar à uma decisão per curiam enquanto a individualidade provocaria uma decisão seriatim. A unanimidade, portanto, sinalizaria sua presença enquanto múltiplas opiniões ecoariam sua ausência. Para o autor, essas inferências devem ser tratadas com cuidado, pois nas cortes em que opiniões múltiplas são proscritas, a presença ou a ausência de "colegialidade" não seria motivo de preocupação. Por outro lado, nas cortes onde opiniões múltiplas são permitidas, os efeitos da "colegialidade" variam. Mesmo assim, em qualquer um desses casos, uma corte deliberativa deve ser colegiada de forma ética e não numérica. (MENDES, 2013) 
$\mathrm{Na}$ definição do autor, "colegialidade" significa o uso construtivo de relacionamentos profissionais na tomada de decisão. Por se preocupar com uma cultura decisória institucional e interna, a qual favoreça a deliberação, essa virtude estaria conectada a um projeto colaborativo para além da busca por unidade. Segundo Mendes, ao invés de consenso, a "colegialidade" implicaria discutir séria e respeitosamente os pontos de vista uns com os outros. Em uma atmosfera de civilidade e respeito, decisores devem estar preparados a ouvir, persuadir e serem persuadidos. (MENDES, 2013)

\section{e) objetivar unanimidade}

Mendes também afirma a "colegialidade" como um conceito guarda-chuva o qual pode se decompor em várias outras virtudes. Assim, a "colegialidade" seria mais abrangente e matizada que uma ética do consenso, mas incluiria o objetivo de unanimidade. Em linhas gerais, esta virtude compreenderia: um certo nível de respeito; um compromisso em argumentar e cooperar; e uma disposição em se esforçar por uma decisão supra-individual. (MENDES, 2013).

\section{f) ter responsabilidade em interagir}

Primeiro o autor ressalta a adjudicação colegiada ser uma agência na qual o desempenho passa do indivíduo ao grupo e sua atuação pertence a corte e não ao decisor em particular. Assim, a "colegialidade" seria uma agulha magnética atraindo em direção à convergência, pois sem essa força gravitacional a interação colegiada se transformaria em mera justificação mútua. Ou seja, esta virtude estaria em desacordo a um decisor o qual não se vê responsável por interagir e se comunicar com seus colegas. Segundo Mendes, este seria um exemplo típico da ausência de "colegialidade". (MENDES, 2013) Esta seria uma das problemáticas encontradas no STF. 


\section{O uso da composição}

Para Mendes, apesar do esforço mútuo em argumentar e persuadir, esta virtude pode arbitrar dilemas éticos os quais se materializam quando o desacordo persiste. Nessas situações, o autor indica que um decisor poderia compor e encontrar um meio-termo, concordar ou, em último recurso, divergir, mas essas saídas alternativas tornariam as cortes imperfeitas. Nesse caso, Mendes sustenta a composição ser uma solução aceitável quando o consenso espontâneo, ou mesmo uma maioria mínima, não surgirem. (MENDES, 2013)

Nesse sentido, razões de segunda ordem poderiam compelir um decisor o qual acredita estar certo a descartar sua primeira escolha e se juntar ao grupo. Segundo o modelo, decisores poderiam fazer concessões em nome do poder simbólico e político de uma decisão unânime, se opondo à susceptibilidade trazida por decisões divididas. Aqui se reafirmará o gerenciamento desta variável política integrar apenas cortes constitucionais as quais permitem opiniões divergentes, conforme veremos no terceiro nível de desempenho. (MENDES, 2013)

\section{g) conter o uso da composição}

O autor ainda nos alerta sobre a composição no domínio da adjudicação chamar atenção à uma aura moral e essa noção se enredaria a tipos menos legítimos de barganha. Para Mendes, a barganha, embora estimulada em outros fóruns, não poderia ser tolerada pelos padrões de imparcialidade que a aplicação do direito envolve. Segundo ele, este seria um modelo de comportamento judicial o qual não identificaria nada além de negociação estratégica em uma corte colegiada. Logo, para alcançar a maioria de um consenso, os decisores devem deliberar e alcançar um compromisso de princípios ao invés de barganharem. (MENDES, 2013) 


\section{Tipos de compromissos}

Nesta linha compromissória, Mendes indica a existência de dois tipos de compromissos não-objetiváveis. Esses compromissos pressupõem um nível de confiança interpessoal o qual apenas a "colegialidade" pode englobar. Segundo o autor, um decisor poderia atingir um compromisso de parceria, divergindo por não haverem sentimentos profundos sobre sua própria posição e valorizando a unidade institucional; ou um compromisso pragmático, divergindo para mudar o status quo de uma direção favorável, embora a solução ainda esteja aquém do ideal. (MENDES, 2013)

No modelo proposto por Mendes, a "colegialidade" rejeitaria comportamentos estratégicos. Segundo o autor, a "colegialidade" deveria levar a um compromisso de princípios quando o acordo espontâneo se revelasse inviável. Mendes, contudo, afirma que embora o desacordo sobreviva quando um compromisso de princípios não seja possível, o órgão colegiado poderia induzir a acomodação de preferências por composição. Para Mendes, ao invés de concordar ou divergir, a vontade em localizar o ponto de conflito e dissolvê-lo implicaria na inclinação de deferência aos colegas. (MENDES, 2013) Mas como isso seria possível no Supremo?

\section{h) encontrar meio-termo}

$\mathrm{O}$ autor enfatiza que explorar mais a fundo para encontrar um meio-termo pode ser mais fácil em uma corte a qual compartilhe uma base de métodos de interpretação. Este seria um recurso habitual ao equilíbrio e a proporcionalidade da decisão. ${ }^{53}$ Existiriam níveis de análise em que a comunicabilidade seria simplesmente rompida, emergindo tal necessidade. (MENDES, 2013)

\footnotetext{
${ }^{53}$ Segundo Mendes, seria o caso do Tribunal Constitucional Alemão, diferentemente da Suprema Corte dos Estados Unidos da América. Sobre o STF, em sua recente fala no V CITI (ver nota 46), André Rufino do Vale criticou a falta de uma "ética da cooperação" entre os ministros. Ao invés das “onze ilhas" de Mendes, preferia atribuir à imagem do STF a alcunha de "onze feudos".
} 


\section{i) evitar divergências}

Para Mendes, esta virtude deliberativa também levaria um decisor a agir corretamente junto aos seus colegas ou esperaria que estes se comportassem como tal. A "colegialidade", porém, não seria incompatível a uma manifestação individual ocasional se esta for institucionalmente permitida. Nesse limite, ela evitaria o risco do excesso de indulgência na escrita da opinião separada e nutriria um estilo de julgamento mesmo em caso de divergência. Assim, de acordo com o autor, haveria uma forte recusa em transformar a decisão de uma corte deliberativa numa vitrine das mentes autônomas dos decisores. (MENDES, 2013)

Na percepção de Mendes, se o direito à divergência for garantido, a "colegialidade" tornará seu exercício oneroso e condicional, pois uma divergência colegiada é percebida como uma medida de último recurso. Dito isto, segundo o autor, a divergência deve proferir as diferenças sem prejudicar a "colegialidade", o respeito público, e também a própria confiança no poder judiciário. De acordo ao modelo, um uso desregrado de divergências seria prejudicial e, em consequência, também às próprias condições para a deliberação. (MENDES, 2013)

\section{O "dilema do divergente"}

Como vemos, as divergências são bem-vindas ao fornecerem uma crítica útil a opinião da corte. Assim, um decisor teria o dever de divergir quando sua opinião pudesse contribuir a correção de uma decisão a qual acreditasse estar errada, mas desde que sua opinião fosse menos onerosa que a aparência de uma corte desintegrada. Segundo Mendes, o decisor equilibraria a vantagem em insistir na sua opinião com a desvantagem criada pela própria expressão da divergência. Ou seja, deve-se equilibrar a vantagem em expressar uma divergência a qual possa tornar-se a opinião da maioria futuramente, com a desvantagem da incerteza a qual uma divergência pode criar no ordenamento jurídico atual. (MENDES, 2013) 


\section{Tipos de divergências}

$\mathrm{Na}$ visão de Mendes, é preciso distinguir entre uma divergência "substituída" por stare decisis; uma divergência "suspensa", caracterizada por uma aquiescência temporária; e uma divergência "sustentada". Esta última, no entanto, se torna problemática por existir um objetivo institucional importante servido pela divergência na primeira vez em que surge. Afinal, a matéria será diferente quando ressurgir uma questão já decidida. Assim, há uma licença para divergir na primeira impressão de um caso enquanto em casos subsequentes, devido as obrigações contrárias trazidas pelo precedente, esta divergência será onerosa. (MENDES, 2013)

Para o autor, a "colegialidade" alimentaria uma dinâmica de grupo pressuposta a um órgão deliberativo. Segundo essa proposta, apresentar uma opinião divergente, ou mesmo pedir um adiamento da decisão, pode ser percebido como algo hostil pelos colegas. Segundo Mendes, um fórum deliberativo deve estar imunizado contra o culto à celebridade, pois a dinâmica de grupo não recepciona "solistas". Logo, o abuso de divergências e de outros tipos de atitudes individualistas, deteriora a capacidade deliberativa da corte. Afinal, os decisores conhecem suas personalidades intelectuais e a interação quotidiana pode consolidar divisões teóricas levando ao impasse. Este desafio, caro à compreensão do STF, será melhor abordado pelas questões de desenho institucional. (MENDES, 2013)

\section{j) acreditar no bem supra-individual}

Finalmente, a "colegialidade" implica mais que deferir aos colegas a fim de encontrar um meio-termo. Para Mendes esta virtude indicaria a crença em um bem supra-individual o qual decisores só poderiam alcançar juntos e do qual depende a respeitabilidade moral de sua decisão. Segundo $\mathrm{o}$ autor, este bem deve superar todas as posições individuais preferidas, pois ao renunciá-lo se privaria a instituição de uma importante fonte de legitimação política. (MENDES, 2013) 
Como constatamos, a "colegialidade" se mostra uma virtude central caso a fase decisória estime cumprir sua tarefa deliberativa, mas a interação colegiada, no entanto, não seria redutível a ela e outras três virtudes complementares ajudam a tipificar suas práticas de forma mais acentuada. A primeira delas seria a "modéstia cognitiva", uma condição lógica e moral para as transformações de preferências pelos decisores.

\section{iii. "Modéstia cognitiva"}

\section{k) desenvolver método da autodúvida.}

Segundo Mendes, a deliberação assume que participantes não aderem às suas disposições pré-deliberativas e também não estão muito seguros sobre conclusões alcançadas individualmente. Por esse motivo, um deliberador poderia se tornar vulnerável ao escrutínio de seus colegas e para isso se estabelecerá a "modéstia cognitiva" como algo o qual a persuasão e as concessões mútuas implicarão lógica e moralmente. (MENDES, 2013)

\section{k) desenvolver método da auto-dúvida}

No modelo de Mendes, a "modéstia cognitiva" seria uma forma de exortar os decisores a investigarem profundamente o que compartilham e a dissolverem mal-entendidos. Assim, ao tomarem as opiniões uns dos outros a sério, os decisores deveriam exercer, até o limite, o método da autodúvida. A deliberação judicial requer, além da virtude da inteligência judicial, a expertise, um equipamento intelectual apropriado para entender e lidar com a complexidade jurídica, também uma atitude despretensiosa em relação ao próprio conhecimento adquirido. (MENDES, 2013) 
Para Mendes, o caráter e o papel da "modéstia cognitiva" se assemelham à noção de caridade interpretativa. Seu objetivo não seria prestar respeito aos interlocutores, mas sim inspirar uma atitude construtiva para a aquisição da percepção por parte deles. Segundo o autor, haveria uma modéstia inerente à função judicial impedindo o absolutamente certo ou apenas uma resposta certa a um problema jurídico específico. Objetivando o aprendizado, portanto, esta virtude seria institucional e não pessoal. (MENDES, 2013)

\section{iv. Ambição cognitiva}

\section{l) buscar a melhor decisão.}

Na visão de Mendes, a "ambição cognitiva" seria o anverso da "modéstia cognitiva". Esta virtude consistiria na vontade institucional da disposição coletiva em se esforçar a persistir na busca da melhor decisão possível. A "ambição cognitiva" abasteceria a "colegialidade" com uma energia investigativa sem a qual a deliberação se tornaria anêmica e fatigada. Segundo o autor, esta virtude forneceria à deliberação um impulso epistêmico mais poderoso que a pura “colegialidade". (MENDES, 2013)

\section{l) buscar a melhor decisão}

Para Mendes, decisores inspirados por essa virtude não estariam contentes com o acordo e tentariam sujeitar uma convergência ocasional a novos testes de argumento. Se os decisores estiverem desconfortáveis com um acordo precipitado, poderiam recorrer a contra-argumentos no estilo "advogado do diabo". Afinal, como indica o autor, decisores se mostram estudantes desafiados por um problema em comum. (MENDES, 2013). 
Dessa maneira, Mendes pontua a articulação entre a "modéstia cognitiva" e a "ambição cognitiva", e também entre uma atitude de autodúvida e um compromisso em persistir na busca da melhor resposta, como meios de maximizar a deliberação em relação às suas atitudes judiciais. Como veremos mais adiante, o desenho institucional proporcionará condições mais adequadas ao florescimento dessas articulações. Por hora, segundo o autor, a interação colegiada seria a configuração onde o ideal de não-hierarquia e do melhor argumento se tornam mais instanciados ao longo da estrutura decisória trifásica. (MENDES, 2013)

\section{v. "Empatia"}

m) utilizar imaginação empática;

n) ter sensibilidade a potenciais leitores.

Para Mendes, esta virtude qualificaria a "ambição cognitiva". Ela relacionaria a capacidade em imaginar indiretamente os pontos de vista que não foram formalmente expressos no decurso do processo judicial. Segundo o autor, quando obstáculos institucionais impedem os interlocutores de argumentarem suas posições completamente, ou quando os próprios interlocutores não conseguem fazer jus à complexidade de um caso, os decisores empáticos poderiam preencher essa lacuna. (MENDES, 2013)

A “empatia" permitiria a corte ampliar a quem os decisores escutam antes de decidirem e a quem eles encorajam a falar depois de decidirem. Esta virtude se preocuparia com a necessidade de tratamento justo aos não representados no caso. Segundo Mendes, a "emparia” indica a complementaridade entre os intercâmbios presentes na fase pré-decisória e a deliberação oriunda da fase decisória. (MENDES, 2013) 


\section{m) utilizar imaginação empática}

Primeiramente, a imaginação empática da potencial comunidade de interlocutores permite uma corte constitucional ir além dos argumentos coletados na fase pré-decisória. Para o autor, este tipo de "empatia" se tornaria relevante a uma instituição vista como elitista e cuja capacidade em ser heterogênea e representativa se mostra enfraquecida. Segundo Mendes, entretanto, o desenho institucional deve ser capaz de atenuar esse efeito. (MENDES, 2013)

\section{n) ter sensibilidade a potenciais leitores}

Por fim, de acordo ao modelo, a "empatia" de uma corte constitucional deve ser sensível aos potenciais leitores de suas opiniões. Para Mendes, essa medida implica levar em conta a maior audiência imaginável e desenvolver uma mentalidade alargada, uma visão ativa a qual capacite a corte elevar-se sobre suas idiossincrasias individuais de modo a cobrir o ponto de vista da comunidade a ser persuadida. Segundo o autor, por mais reduzido que seja o público de qualquer julgamento, o potencial leitor de uma decisão é vasto. O objetivo, portanto, não é agradar ou desagradar a ninguém, mas conversar com rigor, integridade e consciência das responsabilidades constitucionais diante de uma audiência tão ampla quanto possa ser imaginada. ${ }^{54}$ (MENDES, 2013)

\footnotetext{
${ }^{54}$ Diante do STF e a questão da legitimidade política, uma das críticas mais duras e atuais é a do próprio Conrado Hübner Mendes em artigo para o caderno Ilustríssima do jornal Folha de S. Paulo do dia 28/01/2018: "Na prática, ministros do STF agridem a democracia, escreve professor da USP". No artigo, diante do que Mendes atribui como uma "autoimagem construída pelo STF" ao longo do tempo, afirma que no ápice do movimento de "automistificação" [de uma imagem institucional moralizante], o ministro Luis Roberto Barroso declarou imaginar o STF como uma "vanguarda iluminista que empurra a história na direção do progresso moral e civilizatório". Em: https://www1.folha.uol.com.br/ilustrissima/2018/01/1953534-em-espiral-de-autodegradacao-stfvirou-poder-tensionador-diz-professor.shtml. A atuação política de ministros, e a legitimidade das relações inerentes à essa atuação, formariam um ponto crítico em qualquer análise do Supremo.
} 


\section{III - Virtudes na decisão escrita deliberativa}

No modelo de Mendes, a decisão escrita deliberativa conclui o processo deliberativo comunicando ao público qual decisão a interação colegiada foi capaz de produzir e informando o amplo conjunto de argumentos devidamente ponderados. Uma decisão escrita deliberativa expressaria assim, uma identidade institucional des-personificada qual fosse o formato a ser assumido pela corte. (MENDES, 2013)

Para o autor, como já enfatizado, a escolha entre per curiam e seriatim deve ser feita de acordo a certos critérios contextuais. Por mais contraintuitivo que seja a possibilidade de um seriatim des-personificado, existiriam dispositivos institucionais capazes de realizá-lo. Segundo Mendes, a decisão escrita também incorporaria um estilo argumentativo e esse estilo seria um estilo moral. $\mathrm{O}$ estilo moral deliberativo, a princípio, seria uma forma de argumento político matizado, sondado e concreto, mas aberto à divergências. (MENDES, 2013)

Em sua visão, a corte teria a responsabilidade em contar a história sobre um caso de maneira particular e a voz utilizada, desse modo, não poderia ser a de um "oráculo divino" o qual declara soluções aos problemas da vida humana mediante a enunciação de uma sabedoria pura e apartada. Para Mendes, essa narrativa dependeria do exercício de três virtudes principais e essas virtudes se assemelham às três exigências demandadas por cortes juridicamente responsáveis. Daí testar o STF. (MENDES, 2013)

Segundo a tese do autor, essas três virtudes corresponderiam: ao reconhecimento de agência, ao reconhecimento de justificação e ao reconhecimento de interlocução. Ou seja, os cidadãos seriam mais capazes em responder a uma decisão judicial se o decisor: reconhecer a decisão como sua; reconhecer o provimento de razões para o público ser capaz de entendê-la; e reconhecer a necessidade em apoiar práticas as quais permitam desafiar esse tipo de decisão. (MENDES, 2013)

Vejamos, sinteticamente, quais seriam essas virtudes: 


\section{vi. "Capacidade de resposta"}

p) modular o tom da resposta;

Para Mendes, a "capacidade de resposta" implicaria em selecionar qual dos argumentos levantados por interlocutores mereceria uma resposta adequada. Em vez de um dever em responder a tudo o que for expresso publicamente, a corte deve exercer, por uma questão de praticidade e equidade, um julgamento sensato sobre os argumentos. Segundo o autor, este seria o corolário do filtro qualitativo aplicado ao estágio da contestação pública na fase pré-decisória. (MENDES, 2013)

A "capacidade de resposta", ao contrário da mera reação a uma ação anterior, seria orientada por conteúdo. Mendes sublinhará que além dos interlocutores, uma corte responsiva deveria considerar a cadeia de precedentes na qual o caso se insere. Desse modo, a decisão contribuiria a coerência e a sistematicidade do direito. ${ }^{55}$ (MENDES, 2013)

\footnotetext{
${ }^{55}$ Para uma crítica ao STF, recomendamos SILVA, Virgílio Afonso da. Deciding without deliberating. ICON, vol. 11, $n^{\circ} 3,2013$, pp. 557-584. Traçando uma relação sobre compartilhar uma "base de métodos de interpretação", sugerimos o capítulo "Interpretação constitucional e sincretismo metodológico", de Virgílio Afonso da Silva na obra Interpretação Constitucional, publicada pela Editora Malheiros em 2005. Assim, destacamos seu item 4 (quatro), "Métodos de interpretação e sincretismo metodológico”. Para Silva, “[a] mais importante manifestação [...] de sincretismo metodológico [é] a utilização conjunta - ou a ideia de que essa possibilidade existe da teoria estruturante do direito e do sopesamento de direitos fundamentais". No Brasil, segundo o autor, “o apego a uma lista de métodos e princípios de interpretação constitucional, de caráter meramente formal [e incompatíveis entre si], emperra [...] a elaboração de métodos ou critérios que sejam adequados [...], realmente aplicáveis à interpretação constitucional em geral, e da Constituição Brasileira em particular" (sobre o contexto institucional de uma corte constitucional, ver subção 2.3.1.). Em sua fala no V CITI (ver nota 46), Mendes critica o suposto "cânone de boas decisões" sobre direitos fundamentais no STF. Segundo ele, uma "lista de grandes casos não é jurisprudência", pois "não enraíza o tecido argumentativo". Assim, em sua percepção, esse tipo de problema deliberativo indicaria uma "falta de previsibilidade" sobre as decisões da corte brasileira.
} 
vii. "Clareza"

q) transmitir mensagem acessivel;

Como evidenciado, a "clareza” provavelmente é uma virtude muito óbvia para se pedir às decisões judiciais. Para Mendes, embora seja uma qualidade inerente ao próprio Estado de direito, alcança-la enquanto um pré-requisito de comunicação no domínio do raciocínio jurídico significaria um trabalho bastante árduo. Sob o ponto-de-vista do autor, ao qualificar a "capacidade de resposta", a "clareza" exigiria mais que uma inteligibilidade superficial. Assim, segundo Mendes, por não ceder a jargões jurídicos rarefeitos uma decisão escrita deliberativa se opõe a afirmações oraculares. (MENDES, 2013)

\section{viii. "Senso de falibilidade e provisoriedade"}

r) reconhecer reversibilidade, possível erro e continuidade.

Para o autor, a decisão escrita deliberativa expressaria um "senso de falibilidade e provisoriedade" qualificando seu tom. Segundo o modelo, esta virtude requer uma calibração cuidadosa de como a corte prevê ou anuncia a supremacia judicial. Fundamentalmente, a decisão refletiria a consciência da corte acerca do desafio moral contínuo sobre o qual depende a legitimidade das decisões coletivas. Mendes estabelece que a corte deve reconhecer: a decisão como historicamente situada; a possibilidade em ter cometido erros; e o dever da deliberação continuar enquanto o desacordo perseverar ou quando este reaparecer. (MENDES, 2013) 
$\mathrm{O}$ autor menciona que se cidadãos e decisores não justificarem uma escolha autorizada sobre os valores fundamentais da sociedade, devese preservar a possibilidade de um desafio moral contínuo sobre a escolha desses valores. Para Mendes, as decisões judiciais responsáveis devem oferecer oportunidades genuínas para cidadãos responderem a elas e os agentes públicos encorajarem respostas à essas decisões. (MENDES, 2013)

\section{Mentalidade institucional: as práticas e virtudes deliberativas}

Após conferirmos as 9 (nove) práticas e suas 9 (oito) virtudes, passaremos aos instrumentos institucionais capazes de dar-lhes impulso, ou seja, correspondentes à potencialidade do desempenho deliberativo. Logo, ao concluirmos as questões de mentalidade institucional (subseções 2.2.1 e 2.2.2), chegamos à segunda metade dos "facilitadores" do desempenho.

\section{Estruturação do modelo avaliativo}

Primeiro nível $=$ Fases + Capacidades + Tarefas
Segundo nível $=$ Práticas + Virtudes + Instrumentos
Terceiro nível $=$ Contexto + Circunstâncias

$\mathrm{Na}$ próxima subseção (2.2.3), avançaremos sobre as questões de desenho institucional e começaremos o exame dos 10 (dez) instrumentos dispositivos incorporados às tarefas deliberativas. Em seguida, na última subseção (2.2.4), veremos os 5 (cinco) instrumentos constitutivos anteriores a própria fase pré-decisória e inerentes à uma corte constitucional. Assim, classificamos esses últimos sob o termo de "projeto institucional". Em nossa conclusão abordaremos melhor essa distinção. Vejamos as categorias de instrumentos deliberativos a formarem uma arquitetura institucional. 


\subsubsection{Os instrumentos deliberativos dispositivos}

\section{I - Na contestação pública}

Instrumentos

\section{Dilemas}

discricionária, obrigatória ou mista

discricionária, obrigatória ou mista

ii. Definição de agenda filtros amplos ou filtros estreitos estilo contraditório ou inquisitório

II - Na interação colegiada

Instrumentos

v. Sessões

vi. Modo de interação

vii. Capacidade decisória

\section{Dilemas}

públicas ou secretas

formal ou informal; face-a-face ou por escrito unanimidade ou maiorias

\section{III - Na decisão escrita deliberativa}

\section{Instrumentos}

\section{Dilemas}

viii. Exibição pública de desacordo .... per curiam ou seriatim

ix. Redação da decisão menor interação ou maior interação

x. Comunicação da decisão variedade de canais possíveis 


\section{I - Instrumentos na contestação pública ${ }^{56}$}

\section{i. Formação de arquivo}

a) discricionária; b) obrigatória; c) mista

Como sabemos, a fase pré-decisória começaria quando casos fossem levados a corte. Assim, haveria uma decisão sobre quais e quantos casos a serem aceitos. Esses filtros, tanto qualitativos quanto quantitativos, seriam referidos como "formação de arquivo". Para Mendes, o aumento do número de casos poderia atingir um ponto em que a competência e a produção da corte seriam afetados, por esse motivo prioridades sobre os recursos temporais precisam ser definidas. (MENDES, 2013)

Segundo o autor, uma fórmula para alcançar o arquivo ideal envolveria fatores como tempo e quantidade de pressão. Nessa condição, Mendes estabelece o fator tempo (horas e dias) não ser a única consideração prevista e assim chega-se a seguinte equação: $[$ carga $]=[$ tempo $]+[$ pressão $]$. Afinal, um arquivo da dimensão presente do número de casos exerce uma pressão a qual drena energia e desvia a atenção da corte. (MENDES, 2013)

Essa questão, portanto, envolve não apenas o número ótimo de casos e os problemas relevantes e oportunos a serem abordados neles, mas também envolve quem deve tomar essas duas decisões. Para Mendes, em cada caso, deve-se observar a carga de trabalho como uma forte influência sobre a meticulosidade da deliberação e as condições deliberativas de uma corte, pois uma instituição a qual decida vinte ou trinta casos por ano, ou que decida quase cem mil, como é o caso do STF, são bastante diferentes.

\footnotetext{
${ }^{56}$ Como ocorrido diante das virtudes deliberativas (2.2.2), optamos por sintetizar os dilemas envolvidos nos instrumentos dispositivos inerentes à tarefa de contestaçãoo pública. Também, conforme já salientado e dados os limites desta monografia, preferimos focar no detalhamento dos instrumentos dispositivos relacionados às tarefas de interação colegiada e decisão escrita.
} 
Como meios de gerenciar este arquivo, o autor menciona as cortes usarem negativas de acesso direto e recusas à permissão para apelar. A Suprema Corte dos Estados Unidos, por exemplo, utiliza o writ of certiorari para definir de forma discricionária o seu arquivo. (MENDES, 2013)

Por fim, sistemas mistos podem combinar formações obrigatórias e discricionárias em relação a diferentes tipos de ações judiciais. Algumas cortes tem discrição para conceder "licença de recurso" em alguns casos, mas outros casos devem ser "ouvidos por direito". A título de exemplo, o autor inscreve o STF como híbrido no que se refere à instrumentalização de sua formação de arquivo. (MENDES, 2013)

\section{ii. Definição de agenda}

a) discricionária; b) obrigatória; c) mista

Segundo Mendes, a definição da agenda está relacionada ao momento da decisão e aos atos processuais anteriores, uma vez que um caso já foi aceito em seu arquivo. Para ele, decidir se um caso será processado não é o mesmo que decidir quando. O autor supõe que se um caso entrar no arquivo, a corte decidirá necessariamente dentro de um prazo definido sem muita flexibilidade. Ou seja, formal ou informalmente, algumas cortes teriam essa margem de manobra. (MENDES, 2013)

Já no caso brasileiro há uma série de práticas informais toleradas as quais tornam extremamente difícil prever quando um caso será decidido pelo Supremo Tribunal Federal. O Presidente da Corte, posição a qual se alterna a cada dois anos, contrai o poder em definir a agenda e os decisores individuais, por sua vez, podem interromper a deliberação pedindo mais tempo para si em um prazo indeterminado. (MENDES, 2013) 


\section{iii. Caracterização de interlocutores}

a) filtros amplos; b) filtros estreitos

Para Mendes, o grau de diversidade dos potenciais interlocutores é fundamental para determinar o desempenho deliberativo, especialmente, na contestação pública. Segundo o autor, a noção de justiça e o desempenho judicial exigem que a corte e a advocacia atuem em concerto. Esse mesmo conselho se aplicaria ao desempenho deliberativo e por isso a abertura a uma variedade de interlocutores poderia contribuir ao aumento da gama de perspectivas abordadas pela corte. (MENDES, 2013)

Segundo o autor, quando o acesso à jurisdição constitucional é reservado apenas àqueles que podem pagar um alto preço de admissão, a corte é despojada de seu potencial deliberativo. Assim, o acesso à justiça deve ser conceituado à luz do ideal de democracia participativa. ${ }^{57}$ Ao democratizar as regras de acesso, faz-se com que o valor da diversidade dê forma a quem são os decisores e os interlocutores podem originar cortes as quais dificilmente seriam classificadas como "elitistas". Para Mendes, uma instrumentalização fácil e pouco dispendiosa a qualquer cidadão não poderá se apartar das lentes democráticas participativas. (MENDES, 2013)

\footnotetext{
${ }^{57}$ Sobre a questão de democratização do Poder Judiciário no Brasil, recomendamos a recente obra de Maurício Corrêa de Moura Rezende, "Democratização do Poder Judiciário no Brasil", publicada pela Editora Contracorrente, São Paulo, 2018. Ao mesmo tempo, para uma crítica ao Poder Judiciário brasileiro, sugerimos FILHO, Hugo Cavalcanti Melo. Judiciário Oligárquico: déficit democrático e informalidade na administraçãoo dos tribunais e no governo da magistratura no Brasil. São Paulo: LTr, 2014. Também vale mencionar RODRIGUEZ, José Rodrigo. Como decidem as cortes? Para uma crítica do direito (brasileiro). Rio de Janeiro: Editora FGV, 2013. Para refletir a esse respeito, ver a pesquisa sociológica de VIANNA, Luiz Werneck; CARVALHO, Maria Alice Rezende de; MELO, Manuel Palacios Cunha; e BURGOS, Marcelo Baumann. Corpo e alma da magistratura brasileira. Rio de Janeiro: Revan, 1997 - $3^{\mathrm{a}}$ ed.
} 


\section{iv. Modo de interação entre interlocutores e decisores}

a) contraditório; b) inquisitório

Durante a fase pré-decisória do modelo, o modo de interação entre decisores e interlocutores poderia assumir diferentes formas, procedimentos e estilos. Segundo o autor, o modo de interação estrutura a contestação pública e deve fornecer as condições para a virtude da "curiosidade respeitosa" se desenrolar. Nesta etapa, com relação à forma, Mendes nos diz que o argumento de interlocutores e decisores pode combinar encontros presenciais em sessões de audiência e petições escritas. (MENDES, 2013)

Para o autor, acerca do procedimento, o número de petições escritas, além da duração e da quantidade de audiências, também podem ser reguladas de forma flexível a fim de facilitarem uma ampla "assembleia de razões". ${ }^{58}$ Segundo Mendes, em um nível mais geral, no entanto, a corte precisaria adotar algum ponto de vista entre dois estilos de interação: o contraditório e o inquisitório. (MENDES, 2013)

\footnotetext{
${ }^{58}$ Diante da perspectiva de razão deliberativa, recomendamos o panorama de ALARCON, Sylvio. Quem delibera? Representação, imparcialidade e legitimidade na democracia deliberativa. Revista Estudos Jurídicos, n. 23, a. 16, 2012, pp. 187-213. Trazemos sua crítica sobre o desenho institucional do sistema brasileiro de jurisdição constitucional. Para ele, a situação brasileira de ambiguidade em relação a adoção de um sistema concentrado de controle de constitucionalidade, “[...] além de demonstrar que a adoção do modelo europeu-continental [...] não é tão simples quanto parece, indica que o melhor caminho é corrigir as falhas e desenvolver as potencialidade do atual sistema [sem] "transplantar" modelos estrangeiros prontos". Em seguida, acrescenta que "do ponto de vista deliberativo, o arranjo institucional brasileito atual favorece a deliberação externa". Ao mesmo tempo, Alarcon afirmará que "as atenções deveriam se voltar [neste momento] para o aprimoramento da deliberação interna". Em sua percepção, as "práticas completamente informais, como a disposição dos ministros para a persuasão, para a mudança de opinião e para a busca do consenso podem ser muito mais importantes, do ponto de vista deliberativo, do que mudanças institucionais". (grifo nosso) Esta crítica corroboraria à uma melhor interação colegiada no STF.
} 


\section{II - Instrumentos na interação colegiada}

v. Sessões

a) públicas; b) secretas

Para Mendes, este instrumento envolve uma questão de teoria deliberativa sobre espectadores externos assistirem a interação dos decisores. Se trata de um problema encarado pela própria democracia, pois espectadores restringiriam os decisores, especialmente quando estes demonstram sentirem-se responsáveis perante o público. (MENDES, 2013)

$\mathrm{Na}$ visão do autor, a escolha entre publicidade e sigilo e os compromissos aceitáveis entre ambas, será consequente. Como regra geral, uma cultura democrática teria muitas razões em desconfiar da legitimidade de práticas governamentais sigilosas. Segundo Mendes, a transparência seria mais que um slogan enquanto mecanismo de controle democrático, mas de forma contraintuitiva, dependendo de como seja implementada, a transparência prejudicaria a qualidade da deliberação. (MENDES, 2013)

\section{a) públicas}

Mendes menciona que as sessões públicas podem ser um convite à demagogia judicial e excluírem um diálogo genuíno. Decisores poderiam desenvolver uma personalidade pública e uma identidade particular diante do público externo, por isso a publicidade é contrária à "colegialidade". Para evitar vergonha ou constrangimento público, um decisor pode resistir a mudar de opinião enquanto um deliberador deve agir de forma indiferente ao reconhecimento pessoal. Segundo o autor, a publicidade não deve favorecer traços individualistas, mas em sessões públicas uma deliberação autêntica pode não aparecer em primeiro plano. (MENDES, 2013) 
No exemplo de Mendes, o Supremo Tribunal Federal do Brasil teria estabelecido uma tradição sui generis. Para o autor, deixar os decisores deliberarem em público seria considerado como um modelo exemplar de transparência pelo senso comum brasileiro. Segundo Mendes, no entanto, a artificialidade de um encontro público transformado em uma longa leitura não-interativa das opiniões individuais, prejudicaria não apenas a qualidade da deliberação, mas também a racionalidade da própria decisão tomada. (MENDES, 2013)

\section{b) secretas}

Para Mendes, uma ordem de sigilo forneceria a adequada assepsia institucional para a deliberação prosperar e o sigilo combinado à divulgação futura seria a melhor maneira em fazê-lo. Segundo o autor, uma sinceridade genuína nas conferências da corte requer sigilo e tudo o que é sigiloso se degenera. Assim, uma prática em registrar sessões secretas para divulgação futura seria um exemplo de meio-termo. Mendes enfatiza o essa solução se tornar uma resposta ao dilema, pois promoveria um tipo diferenciado de transparência mesmo que tardiamente. (MENDES, 2013)

\section{vi. Modo de interação entre decisores}

a) face-a-face ou por escrito; b) formal ou informal

Segundo o autor, a interação entre decisores pode ser bastante regulada e práticas enraizadas podem tanto favorecer quanto reprimir a deliberação. Assim, no modelo de Mendes, as razões públicas poderiam ser trocadas mediante uma interação face a face e também por intermédio de manifestações escritas. (MENDES, 2013). 


\section{a) face-a-face ou por escrito}

Para o autor, na troca de razões por escrito, uma parte da fase decisória seria incorporada à tarefa pós-decisória de elaboração da decisão. Segundo Mendes, a interação decisória pode acontecer formalmente, por intermédio de convenções mais disciplinadas, ou mesmo informalmente, mas qual combinação dessas variáveis será a mais benéfica à deliberação é uma questão a ser enfrentada por cada corte. (MENDES, 2013)

O autor menciona a Suprema Corte dos Estados Unidos adotar uma mistura de mecanismos. Ela começa por uma conferência face-a-face a portas fechadas enquanto a opinião da maioria é definida. A conferência é seguida por meses de circulação de pareceres. Esta comunicação interna prossegue mediante os memorandos escritos, a circulação desses pareceres rascunhados e finalmente os comentários sobre esses rascunhos. Para Mendes, este método torna-se uma troca rápida para verificar se haveria consenso ou não entre os decisores da corte. ${ }^{59}$ (MENDES, 2013)

Segundo o autor, além das reuniões formais, haveria um processo dinâmico de discussão sobre os casos antes deles serem ouvidos durante a audiência, e também depois delas, por meio de reuniões sobre os rascunhos circulados. Mendes conclui que à medida em que a interação se torna cada vez mais rígida e codificada, a deliberação perde espontaneidade e implica em oportunidades de um decisor influenciar na decisão. (MENDES, 2013)

Para o autor, assim se desenha uma distinção entre a afirmação dos pontos de vista preliminares e a deliberação em si: uma declaração de pontos de vista e de razões poderia indicar como o decisor espera opinar, mas nenhum decisor deve opinar antes de ouvir as análises de todos os outros decisores. Segundo Mendes, por ser possível que todos os pontos de vista tenham efeitos sobre a opinião de cada decisor, os primeiros a falar devem permanecer livres para mudarem de opinião. (MENDES, 2013)

\footnotetext{
${ }^{59}$ Para uma imagem romantizada desta tradição, sob o contexto do polêmico julgamento realizado em 1967 nos E.UA., recomenda-se o longa-metragem “Muhhamad Ali’s greatest fight” (2013).
} 


\section{b) formal ou informal}

O autor também sustenta que as virtudes de "colegialidade", "ambição epistêmica", "modéstia epistêmica" e "empatia" não emergem e nem evoluem por meio do desenho institucional formal, mas a completa ausência de regras pode enfraquecer essas virtudes e provocar falhas deliberativas. Para Mendes, a "colegialidade" não consiste em conversas espontâneas, mas em deliberações ordenadas em que todos os pontos de vista são exibidos e considerados para satisfação de todos os decisores. Segundo o autor, um tipo de restrição a participação de cada decisor pode evitar que seus pontos de vista não sejam expostos ao grupo. Assim, um dos maiores obstáculos para alcançar os benefícios da diversidade seria a ineficácia na extração e integração de perspectivas concorrentes entre os membros de uma corte. (MENDES, 2013)

\section{O papel do relator}

Nesse sentido, uma quantidade de fórmulas poderia ser imaginada. $\mathrm{Na}$ visão de Mendes, estas fórmulas podem basear-se nas práticas históricas da adjudicação colegiada. Para ele, uma tradição típica atribui ao relator (rapporteur) um conjunto de funções relacionadas: administrar como o caso evolui procedimentalmente; conduzir as deliberações internas; e ser o principal redator da decisão (caso o desacordo não exija que outra pessoa escreva a opinião da maioria). (MENDES, 2013)

Para Mendes, o critério de escolha do relator deve ser pensado em termos deliberativos, por exemplo, a especialização jurídica específica de cada decisor ser levada em consideração para aumentar o potencial epistemológico da decisão e também a eficiência na coleta de informações. A partir disso, o autor supõe o relator como uma liderança em todo o processo, mas a forma como essa liderança será exercida, além de como os outros decisores responderão à ela, se tornará crucial para as perspectivas de deliberação. (MENDES, 2013) 
Segundo o autor, em certas cortes, as tradições da adjudicação colegiada permitem ao decisor principal - o presidente da corte - tomar a liderança geral do processo. Outras, no entanto, seriam mais atomizadas e confeririam um papel burocrático marginal tanto ao relator quanto ao decisor principal. Como arquétipo de corte atomística, o autor recorre ao exemplo do próprio Supremo Tribunal Federal. Contudo, seja qual for a melhor estratégia em cada circunstância, o desenho institucional não poderá subestimar a forma como a deliberação é estimulada e melhorada por esse tipo de regra interna. (MENDES, 2013)

\section{vii. Capacidade decisória}

a) unanimidade; b) maioria simples e maioria qualificada

Mendes afirma que a deliberação pressupõe a necessidade em tomar uma decisão coletiva e deve haver um padrão de "capacidade decisória" para definir quando uma solução autorizada foi alcançada e o processo chegou ao seu fim. Para o autor, deve haver um método para converter "muitas opiniões" em "uma" e esse padrão pode variar entre: a regra de unanimidade; a regra de maioria simples; e a regra de maioria qualificada. (MENDES, 2013)

Segundo o modelo, escolher um padrão de capacidade decisória não deve se confundir com a escolha entre decisão per curiam ou seriatim. Apesar de contraintuitivo, uma corte pode decidir com base na regra de maioria e manifestar-se publicamente por meio de uma opinião per curiam, ou mesmo adotar a regra de unanimidade, mas deixar os julgadores individuais escreverem seu próprio raciocínio. Esta distinção, para Mendes, só fará sentido se a corte deliberar em sessões secretas. (MENDES, 2013) 


\section{a) unanimidade}

Para Mendes, quando a regra da unanimidade estiver em jogo haverá uma pressão maior para deliberar. No entanto, o poder de um único indivíduo em impedir a decisão pode se tornar excessivamente obstrutivo e forçar a compromissos inaceitáveis em prol do consenso. Segundo o autor, caso este dispositivo não esteja acompanhado por uma ética voltada à "colegialidade", se encorajará a barganha ao invés da deliberação. Desse modo, mesmo quando a justiça interna entre decisores não seja vista como um valor político intrínseco, a regra da unanimidade pode se tornar imprudente caso impeça a deliberação. (MENDES, 2013)

\section{b) maioria simples e maioria qualificada}

Por fim, o autor alega a regra da maioria simples como método tradicional de agregação contendo um apelo moral - o igual valor de cada indivíduo - e uma dimensão física - prevalece a força da maioria -. Segundo Mendes, a extensão da persuasão exigida pela regra de maioria simples é menos ambiciosa e pode encorajar outro tipo de comportamento estratégico interno: caso não se alcance um consenso, a barganha pode ser usada para formar coalizões. Para o autor, uma forma de maioria qualificada poderia encontrar o equilíbrio entre esses extremos, mas ainda assim não haveria um método de agregação mais deliberativo. A forma como cada critério funcionará depende de como os decisores compreendem seu papel dentro de um órgão colegiado. (MENDES, 2013)

O autor ainda adverte que um protocolo de votação seria uma complexidade adicional de determinação. Mendes recomenda que em casos de múltiplas questões, onde as perspectivas de dilema discursivo sejam elevadas, uma meta-deliberação sobre o protocolo de votação (um "metavoto") deve ser realizada. Para ele, a questão sobre qual protocolo de votação (questão-por-questão ou resultado-por-resultado) tornaria a corte mais deliberativa não está respondida. (MENDES, 2013) 


\section{III - Instrumentos na decisão escrita deliberativa}

viii. Exibição pública de desacordo

a) per curiam; b) seriatim

$\mathrm{Na}$ tese de Mendes, a decisão escrita deliberativa teria dimensões retrospectivas e prospectivas. Ela costuma filtrar os precedentes e os novos argumentos ou informações a serem reconhecidos publicamente como relevantes para a decisão. Segundo o autor, a decisão estabeleceria como será formado um novo precedente aos casos futuros e contribuiria diacronicamente à construção do ordenamento jurídico. (MENDES, 2013)

Para Mendes, caso a decisão não seja unânime e se existirem razões para a unidade as quais superem o valor da divulgação do desacordo, ela continua a ser decidida por uma questão de segunda ordem. Afinal, a forma como a corte comunica sua decisão deve inculcar o sentimento de respeito pelas partes interessadas e, adicionalmente, iluminá-las em uma discussão de princípios. ${ }^{60}$ (MENDES, 2013)

\footnotetext{
${ }^{60}$ Recomendamos VOJVODIC, Adriana de Moraes et al. A construção das decisões na jurisdição constitucional: atores e deliberação no Supremo Tribunal Federal. In: Flávia Martins de Carvalho e José Ribas Vieira. Desafios da Constituição: Democracia e Estado no Século XXI. Rio de Janeiro: UFRJ, 2011, pp. 73-91. Segundo sua conclusão, “a jurisprudência do Tribunal é constantemente dividida pelos estudiosos especialmente em função das tarefas atribuídas aos ministros em relação ao tipo de decisão. [No STF] são tomadas [decisões] sem que os casos passem por qualquer tipo de colegiado. [...] Ainda que as regras do processo decisório determinem a votação colegiada do Tribunal, as decisões são construídas [...] de modo não colaborativo. Os debates existentes [...] não levam a qualquer alteração no conteúdo da decisão final, sem qualquer preocupação com uma convergência nas posições. [...] Nesse sentido, [...] ainda que o Tribunal não apresente diferentes razões de decidir [ratio decidendi] na maioria dos casos, a corte continua distante do ideal deliberativo, uma vez que o diálogo não faz diferença no resultado final. [A] promoção de um processo deliberativo mais consensual é preferível [...] mesmo que o resultado [...] venha a ser quase sempre o mesmo, a adoção da posição do Relator”. Ver tópico “O papel do relator” (p. 90).
} 


\section{Exibindo a natureza da corte}

O autor reforça o fato de toda essa discussão se tornar inútil caso as sessões internas de deliberação não sejam secretas. Mendes então pondera que mesmo a divergência sendo exposta graças à publicidade da deliberação, não decorreria necessariamente o seu registro na própria decisão escrita. Diante do modelo, a principal escolha a ser feita é como a natureza colegiada da corte será exibida. (MENDES, 2013)

Para o autor, uma coisa seria estabelecer um critério para se chegar a uma decisão coletiva e uma outra coisa seria definir como as divisões ocasionais serão exibidas publicamente em caso de padrões não-unânimes. Segundo Mendes, esses dois fatores podem ser incorporados na prática, mas devido as cortes terem o poder em decidir maioritariamente e se comunicarem em uníssono, não haveria tal necessidade. Assim, na visão do autor, existiria uma distinção entre determinação e exibição pública. (MENDES, 2013)

Abaixo seguem as opções para exibição de decisões não-unânimes. Para Mendes, como tanto vimos, a decisão escrita deliberativa não exigiria um formato específico. Segundo o autor, opiniões únicas (per curiam) ou plurais (seriatim) não seriam as traduções absolutas de um alto desempenho deliberativo. Contudo, por estar preocupado em instilar a deliberação, um desenho institucional não deve fornecer incentivos para que decisores se entreguem à sua própria individualidade. (MENDES, 2013) Vejamos.

Modos de exibição pública de decisões não-unânimes

a) per curiam .... voz única ...... "maiorias" ... s/ publicação de desacordo per curiam .... voz única ...... "maiorias" ... c/ publicação de desacordo b) seriatim ....... voz múltipla ... "maiorias" ... dispensa as especificidades 


\section{a) per curiam não-unânime}

Como observado, o autor diz que a decisão por maioria poderia ser anunciada como decisão do todo (per curiam) e as divergências ocasionais permanecem publicamente desconhecidas. Ou seja, mesmo com a falta de consenso interno, ainda se pode optar por mostrar unanimidade ao público. Afinal, um decisor pode ser minoritário, mas prefere não publicar uma opinião divergente. Segundo Mendes, por outro lado, as cortes podem chegar ao consenso, mas permitirem aos decisores individuais elaborarem $\mathrm{e}$ publicarem suas próprias opiniões convergentes no espírito da tradição seriatim, conforme o quadro acima indicou. (MENDES, 2013)

\section{b) seriatim não-unânime}

Para o autor, a condicionante da "colegialidade" seria oferecida como um vetor centrípeto mais forte que o centrífugo, mesmo quando este último continuar presente. Segundo Mendes, a "colegialidade" não exige uma integração forçada, mas também evitaria uma desintegração nãoconsolidada. Assim, para retornarmos à distinção entre opiniões per curiam e seriatim, sejam elas deliberativas ou não-deliberativas, uma seriatim não precisaria incorporar essa desintegração não-consolidada na medida em que as opiniões conversam entre si. Vide o próprio quadro. (MENDES, 2013)

\section{Proibição de divergências e concorrências}

$\mathrm{Na}$ percepção do autor, uma proibição geral de divergências e concorrências, em vez de aumentar a "colegialidade", pode prejudicar as condições de alimenta-la. Por membros estarem mais dispostos a divergir, essa virtude visaria aumentar a coerência em grupos colegiados nos quais decisores se sentem confortáveis em manifestar seu desentendimento. Para Mendes, essa proibição também pode privar o público de um padrão de crítica e de controle sobre a opinião da corte. (MENDES, 2013) 
Assim, na percepção do autor, o direito à divergência poderia ser reivindicado como antídoto à uma subserviência política. Mendes destaca a importância das divergências para a independência dos decisores. Segundo o autor, quando uma unanimidade pode ser obtida sem o sacrifício da convicção, é fortemente recomendável uma decisão de confiança pública. Em sua tese, uma unanimidade meramente formal registrada à custa de fortes pontos de vista conflitantes não é desejável a uma corte de último recurso, qualquer que seja o seu possível efeito sobre a opinião pública. Assim, o que deve sustentar a confiança pública na corte seria justamente o caráter e a independência de seus decisores. (MENDES, 2013)

\section{Falsa unanimidade}

Para Mendes, opiniões únicas (per curiam) contribuem a algumas qualidades formais do Estado de direito, como clareza e certeza, mas a obrigatoriedade em alcançar um texto unitário pode, no entanto, contribuir inesperadamente a opacidade e a ambiguidade na decisão. Em vez da clareza, pode se ter uma "unanimidade falsa". Segundo o autor, este defeito reverberaria um fluxo de críticas contra as decisões unânimes produzidas pelas cortes, pois esses tipos de decisões poderiam ser vagas o suficiente para que ambos os lados reivindicassem a vitória in casu. (MENDES, 2013)

Ademais, Mendes menciona a opinião única conter dois tipos de perigo. No primeiro deles, por refletirem um maior denominador comum, as opiniões únicas não teriam atenção a detalhes e a percepções individuais e por esse motivo impediriam o desenvolvimento do direito. No segundo perigo, as cortes poderiam se tornar opressivas por um único julgamento com todos os seus compromissos inevitáveis e trazer falsas certezas sobre direitos incertos. Sob este perigo, concorrências teriam o efeito de sinalizar a presença de pontos de vista conflitantes, trazendo uma possibilidade em aumentar a capacidade comunicativa da corte. (MENDES, 2013) 


\section{Divergências anônimas}

De acordo com o autor, a realização de compensações não deixaria de implicar alguma perda. Segundo Mendes, circunstâncias e culturas específicas poderiam aliviar ou intensificar essas perdas. Assim, forçar um acordo a qualquer preço ou ser demasiado permissivo a qualquer tipo de desacordo seriam escolhas imprudentes. Para o autor, permitir os decisores publicarem divergências anônimas é uma invenção criativa a qual pode atuar contra a retórica e a demagogia judiciais. (MENDES, 2013)

Mendes ainda sustenta que essas formas de compensação devem ser definidas antecipadamente, seja por uma regra geral ou decididas caso a caso. Dependendo da cultura interna, o autor alerta sobre este dilema não admitir resposta única e universal. Segundo a tradição, o civil law fundiria anonimato e unanimidade, mas essa fusão não seria inevitável se decisores individuais pudessem divergir e permanecerem anônimos. Para o autor, esta seria um modo de desativar decisões seriatim na corte. (MENDES, 2013)

\section{ix. Redação da decisão}

a) menor interação; b) maior interação

Segundo Mendes, uma decisão escrita a qual congregue a posição de mais de um decisor individual envolve coautoria, ou seja, uma opinião unânime, uma opinião majoritária ou uma divergência conjunta da corte requerem algum acordo sobre como elaborá-las coletivamente. Para o autor, um tipo ótimo de processo em equipe precisará ser definido e essa medida não deve ser problemática. Em sua tese, o processo de redação pode ser uma extensão da deliberação face a face, valendo lembrar que esta variável costuma se sobrepor a um modo escrito de interação. (MENDES, 2013) 


\section{a) menor interação}

$\mathrm{Na}$ visão do autor, cortes geralmente atribuem a tarefa de redigir uma decisão conjunta a um decisor individual. Como vimos, onde houver um relator essa tarefa será cobrada a ele, a menos que acabe apresentando uma opinião divergente. Assim, por razões de praticidade e clareza, haveria um consenso sobre a escrita de opiniões conjuntas ser trabalho para um único decisor. Segundo Mendes, isso minimizaria o risco de ambiguidade, embora não o eliminasse. (MENDES, 2013)

Para o autor, haveria certa dificuldade em escrever a opinião da maioria por ser necessário criar artesanalmente uma opinião tolerável a um segmento enquanto fosse, ao mesmo tempo, suportável ao outro. Assim, escrever opiniões capazes de apaziguar todos os indivíduos de uma maioria exige muita habilidade. Segundo Mendes, a possibilidade da divergência se tornar um incentivo ao julgamento da opinião pública, e também a perspectiva de uma divergência ou concordância apartadas apontarem as imprecisões e insuficiências de uma opinião, aumentaria os incentivos para um redator produzir a decisão da melhor forma possível. (MENDES, 2013)

\section{b) maior interação}

Para Mendes, não obstante a probabilidade de maior ambiguidade, as opiniões conjuntas (seriatim) teriam, em compensação, maiores chances de produzirem uma clara ratio decidendi ao caso. Segundo o autor, devido a sobreposição de um consenso visível permear as opiniões separadas de uma decisão seriatim, uma opinião conjunta em nome da corte terá maiores chances em definir precedentes de forma efetiva. Mendes ainda argumenta que essa situação dependerá da consistência do precedente pois pode se tratar apenas da conservação da decisão em vez de sua ratio decidendi ou ser a hipótese de uma decisão seriatim com opiniões inteiramente diferentes constituindo o precedente. (MENDES, 2013) 


\section{x. Comunicação da decisão}

a) variedade de canais possíveis

Para o autor a decisão escrita seria o principal instrumento de comunicação entre a corte e o público. Segundo Mendes, no entanto, podem haver instrumentos comunicativos suplementares. Afinal, uma corte a qual preza por seu papel deliberativo não deve ignorar a variedade de estratégias possíveis para se comunicar com o público em geral. (MENDES, 2013)

\section{a) variedade de canais possíveis}

Segundo Mendes, algumas vezes as cortes produzem declarações resumidas da ratio decidendi e implementam outros tipos de técnicas informativas. As cortes também podem considerar mecanismos orais para anunciar suas decisões ou mesmo dissensões e estes, ao invés da exposição argumentativa complexa e geralmente longa da decisão, podem ser cruciais para como a deliberação externa se sucederá. (MENDES, 2013)

Para o autor, além de comunicar decisões específicas, uma corte constitucional pode criar um momento público quando anunciar, na fase pré-decisória, sua agenda sobre os próximos casos, ou ainda, na fase pósdecisória, reportar os casos que foram decididos durante um determinado período. Dessa maneira, diferentes tipos de interlocutores terão variados graus de interesse na decisão e também uma capacidade diversificada para se comprometerem à decisão. Ainda, segundo a distinção feita por Mendes, haveria uma maneira adequada para falar aos "públicos contínuos", como a comunidade jurídica, e aos "públicos intermitentes", como os interlocutores de algum modo conectados a uma causa em particular. (MENDES, 2013) 


\section{Desenho institucional: os instrumentos dispositivos}

Após visualizarmos os instrumentos dispositivos da deliberação (2.2.3), estes responsáveis pelo desenho institucional e distribuídos entre as três tarefas deliberativas - contestação pública; interação colegiada; e decisão escrita deliberativa, passamos então aos instrumentos constitutivos da deliberação (2.2.4). Esta categoria de instrumentos, como o próprio termo indica, será encontrada no âmago de uma corte constitucional e se refere ao que compreendemos como projeto institucional. ${ }^{61}$

Por essa razão esses instrumentos não se encontrarão distribuídos entre as tarefas por estarem vinculados à uma espécie de matriz do desenho institucional. ${ }^{62}$ Os instrumentos restantes e seus respectivos dilemas estarão dispostos a seguir e serão os últimos componentes da segunda varíavel, o nível dos "facilitadores" do desempenho deliberativo (2.2) ${ }^{63}$

\footnotetext{
${ }^{61}$ Sobre esse aspecto corporativo, a formação histórica dos tribunais e da magistratura brasileira se mostram elementos importantes para se compreender a "arquitetura institucional" do STF. Diante de uma perspectiva histórica sobre projeto, portanto, recomendamos CONTINENTINO, Marcelo Casseb. História do controle de constitucionalidade das leis no Brasil - Percursos do pensamento constitucional no século XIX (1824-1891). São Paulo: Almedina, 2015. Seguindo a linha do historiador brasilianista Stuart Schwartz na obra Burocracia e sociedade no Brasil colonial: o Tribunal Superior da Bahia e seus desembargadores (1609-1751), temos a obra de WEHLING, Arno e WEHLING, Maria José. Direito e justiça no Brasil colonial: o Tribunal da Relação do Rio de Janeiro (1751-1808). Rio de Janeiro: Renovar, 2004; e ainda mais recentemente, BICALHO, Maria Fernanda; ASSIS, Virgínia Maria Almoêdo de; e MELLO, Isabele de Matos Pereira de. Justiça no Brasil colonial - agentes e práticas. São Paulo: Alameda, 2016. Enfatizamos se observar literaturas ns campos história do direito brasileiro e história do direito latino-americano.

${ }^{62}$ Para Mendes, cortes constitucionais do mundo real fornecem um menu limitado de combinações institucionais. Várias escolhas tornaram-se naturalizadas. Elas sobrevivem quase inquestionáveis e por um padrão não-pensativo. Assim, não se deveria tomar essas escolhas contingentes por certo $\mathrm{e}$ perder de vista as alternativas que possam ser experimentadas. Logo, o desenho ideal de uma instituição atribuída com a função de deliberação constitucional diária é uma questão em aberto.

${ }^{63}$ Ainda sobre o que seriam os "mecanismos de instrumentalização da legitimidade", indicamos a leitura do artigo RANGEL, Henrique; BOLONHA, Carlos; e SEPULVEDA, Antonio. Cortes constitucionais e instrumentalização da legitimidade. Londrina: Revista do Direito Público, n. 1, v. 10, jan./abr. 2015, pp. 171-187. Recomendamos ver a ideia de "constitucionalismo popular".
} 


\subsubsection{Os instrumentos deliberativos constitutivos}

A subseção anterior teve as fases deliberativas como critério a orientar os instrumentos institucionais dispositivos. Além deles, no entanto, haveria uma preocupação institucional anterior a fase pré-decisória. Como podemos conferir no quadro abaixo, essa preocupação estaria relacionada aos instrumentos institucionais constitutivos, os principais recursos da própria instituição.

Dilemas

xi. Localização institucional especializada ou não-especializada xii. Número de decisores muito poucos ou poucos

xiii. Caracterização de decisores diversidade ou homogeneidade

xiv. Modo de indicação partidário ou consensual

xv. Mandato fixo ou vitalício

Os instrumentos institucionais compreendem artifícios capazes de impactar diretamente o desempenho deliberativo. Logo, as duas categorias - dispositivo e constitutivo - combinam desenhos institucionais de "longo" e de "curto" alcances. Os instrumentos constitutivos costumam se referir a escolhas de desenho institucional em grande escala enquanto instrumentos dispositivos se relacionam as escolhas em pequena escala. Essas últimas precisariam ser decretadas uma vez que as anteriores já estivessem definidas. Para Mendes, no entanto, a distinção entre essas categorias não seria de tipo, mas de grau e assim permitiriam visualizar algumas reformas incrementais sobre a corte conforme a seguir. (MENDES, 2013) 


Longo alcance $\quad>>>>\quad$ Curto Alcance
Instrumentos constitutivos

Como afirmamos acima, quando nos movemos sobre o espectro entre instrumentos constitutivos e instrumentos dispositivos, suas naturezas também tendem a passar de um desenho institucional de longo alcance a um desenho de curto alcance. Até agora, a maioria dos instrumentos exibidos em seu conjunto esperou mostrar que melhorias deliberativas significativas podem exigir retoques institucionais ao invés de redesenhos monumentais. Assim, após o desenho institucional de "curto" alcance, os instrumentos dispositivos, passamos ao que Mendes descreve como desenho de "longo" alcance, os instrumentos constitutivos. (MENDES, 2013)

\section{xi. Localização institucional}

a) especializada; b) não-especializada.

Neste primeiro aspecto, Mendes pergunta se a corte ápice do sistema seria especializada em questões constitucionais ou generalista. Para o autor, haveriam dois tipos ideais de cortes constitucionais de acordo a tipologia convencional. Essas duas classificações seriam as cortes de tipo kelseniano, as quais colocam uma revisão judicial concentrada e abstrata em uma corte especializada; ou as de tipo estadunidense, correspondendo ao controle difuso e concentrado em uma corte não-especializada, a qual se encarrega de processar o recurso final. (MENDES, 2013) 
Para o autor, a partir desse ponto de partida classificatório, esses dois sistemas isolados em bloco seriam classificados como "mistos". Segundo Mendes, no entanto, uma tipologia mais refinada de desenho constitucional comparativo apontaria a dois eixos de variação. Conforme o quadro a seguir, no eixo horizontal, relacionado à organização funcional, encontramos as cortes generalistas e as especialistas; já no eixo vertical, relacionado aos diferentes níveis de governo, a jurisdição de apelação dessas cortes poderia ser centralizada ou descentralizada. (MENDES, 2013)

\section{Eixos de variação do desenho constitucional}

Organização funcional generalista ou especialista Níveis de governo (jurisdição) centralizada ou descentralizada

$\mathrm{O}$ autor questiona a existência de algum benefício deliberativo em uma corte especializada. Para Mendes, cortes especialistas podem fazer mais que apenas exercer o controle abstrato no qual litigantes têm acesso direto à jurisdição original da corte. Elas também podem fazer a revisão concreta quando casos comuns, os quais provocam um incidente constitucional, são encaminhados. ${ }^{64}$ (MENDES, 2013)

Segundo Mendes, cortes não-especializadas (generalistas), as quais acumulam a jurisdição constitucional e ordinária, permitiriam os casos ordinários emergirem sobre os casos constitucionais. Sob esse molde, a revisão constitucional se tornaria apenas mais uma competência diluída entre muitas outras e isso traria desvantagens. (MENDES, 2013)

\footnotetext{
${ }^{64}$ Indicamos a leitura da exposição do Ministro Gilmar Ferreira Mendes em evento realizado na cidade de Washington (E.U.A.), em 12/05/2011: "Diálogo Judicial Brasil-Estados Unidos - 2011". Disponível em: https://www.portaldeperiodicos.idp.edu.br/observatorio/article/view/551/0.
} 


\section{xii. Número de decisores}

a) muito poucos; b) poucos.

Para o autor, o tamanho de cortes constitucionais não costuma ser determinado por uma reflexão teórica acerca de sua função institucional. Segundo a tese de Mendes, os enfrentamentos políticos e as preocupações gerenciais poderiam explicar melhor as escolhas numéricas. Mendes usa como exemplo a relação entre o governo de Franklin Delano Roosevelt e a Suprema Corte dos Estados Unidos nos anos de 1930, além das medidas de contenção a autoridade da corte, como nos casos de Brasil e Argentina a partir dos idos de $1960 .^{65}$ (MENDES, 2013)

No modelo, o tamanho ideal de um fórum deliberativo definiria uma de suas características cruciais e circunscreveria o que seria esperado a fazer. Segundo Mendes, seja escolhido deliberadamente ou por acaso, o tamanho de uma corte contém consequências institucionais. $\mathrm{O}$ autor então discute como o "número de cabeças" afetaria a capacidade epistêmica dos órgãos decisórios. Para o autor não haveria como sair de uma análise de custo e benefício entre "muitos" e "poucos". (MENDES, 2013)

Na tese de Mendes, essa questão quantitativa não precisaria atingir um número nítido, mas padrões distintos tendem a produzir diferentes implicações. Afinal, conforme propõe o autor, os órgãos colegiados são melhores em realizar algumas tarefas ao invés de outras. Para Mendes, historicamente, cortes em geral variam entre as magnitudes de três e quinze membros, embora isto não seja tomado como absoluto. (MENDES, 2013)

\footnotetext{
${ }^{65}$ No caso do STF, faz-se referência ao Ato Institucional $n^{\mathrm{o}} 2$ de 27/10/1965. Ver a matéria de Mariana Oliveira para o especial "50 anos do Golpe Militar", publicado pelo portal de notícias GI e disponível em: http://g1.globo.com/politica/50-anos-do-golpe-militar/noticia/2014/03/golpe-de1964-fez-do-supremo-um-enfeite-institucional-diz-pesquisador.html. Acesso em abril de 2018.
} 
xiii. Caracterização de decisores

a) diversidade; b) homogeneidade.

Para Mendes, nos últimos tempos, uma das marcas em debates sobre reforma judicial seria o valor da diversidade. Assim, a questão de um judiciário mais diversificado não buscaria apenas uma qualidade diante da oportunidade em refletir a diversidade da sociedade, também haveria uma razão epistêmica por decisores extraídos de uma vasta gama de cenários e experiências oferecerem diferentes perspectivas as questões judiciais mais críticas. (MENDES, 2013)

O autor também acentua a importância de se constituir uma corte não-homogênea, amplamente representativa da população, incorporando diferentes campos, experiências e perspectivas de quem é servido por ela. Segundo Mendes, a diversidade numérica não deveria tratar apenas de números, pois haveria uma óbvia conexão com o potencial deliberativo da corte. Desse modo, o autor defende fóruns plurais serem mais deliberativos e proficientes quando levarem uma maior variedade de experiências e percepções adiante. ${ }^{66}$ (MENDES, 2013)

xiv. Modo de indicação

a) partidário; b) consensual.

\footnotetext{
${ }^{66}$ Sublinhamos este ser um dos pontos mais sensíveis a respeito dos instrumentos constitutivos e da relação, não só entre judiciário e democracia, mas também entre direito e política. O perfil da magistratura, especialmente as formas de recrutamento em cortes constitucionais, figura como um dos aspectos mais relevantes acerca de um processo para legitimação política e democratização.
} 
Para implementar qualquer valor em relação a quem deve sentar em uma corte constitucional, um procedimento de indicação deve ser definido. Mendes nos informa que a indicação pode ser uma ferramenta legítima em si mesma. Segundo o autor, a natureza do processo político o qual leva à indicação poderia abrir caminhos mais amplos ou mais estreitos em relação a participação de diversos atores. Para Mendes, esta seria uma questão normativa primária de desenho institucional e as técnicas existentes de indicação para cortes constitucionais tenderiam a seguir a dicotomia inicial entre os modelos estadunidense e kelseniano. (MENDES, 2013)

Na visão de Mendes, o desafio para o desenho institucional seria elaborar um procedimento capaz de aumentar as chances de uma ótima composição da corte. Assim, seria necessário decidir quem deve possuir o poder em indicar e o quão discricionário esse poder deve ser exercido. Se houverem razões para não confiar em um uso judicioso, tal prerrogativa pode ser regulamentada de forma mais estrita, mas além de instrumental, também conterá uma função legitimatória da corte. (MENDES, 2013)

\section{xv. Mandato}

a) fixo; b) vitalício.

Ainda, na lição do autor, um dos principais instrumentos a forjar independência e imparcialidade judicial seria a garantia do julgador não ser removido do cargo e não ter qualquer preocupação em agradar o eleitorado. Segundo Mendes, essa estabilidade seria construída mediante um único mandato não renovável, como nas cortes kelsenianas, ou por intermédio de um mandato vitalício, como acontece na Suprema Corte dos Estados Unidos. (MENDES, 2013) 
Nesse limite, o autor prediz a existência de inúmeras variações a modularem a duração de um mandato e estabelecerem uma idade de aposentadoria compulsória. Para Conrado, este seria o caso brasileiro, no qual a Constituição Federal (art. 40) exigia a aposentadoria compulsória dos decisores aos 70 (setenta) anos de idade, agora acrescidos por mais 5 (cinco) anos via emenda. Logo, a vigência do mandato e o procedimento de indicação seriam mecanismos conjuntos para se enfrentar o risco de um partidarismo. Segundo a tese de Mendes, a quantidade de tempo em que decisores permanecessem no cargo e a forma como a composição da corte fosse gradual e permanentemente renovada moldariam a dinâmica de grupo. Essa dinâmica, no entanto, ainda poderia afetar a qualidade da deliberação de forma positiva ou negativa. (MENDES, 2013)

\section{Projeto institucional e instrumentos constitutivos}

Concluída esta segunda variável, o nível dos "facilitadores" do desempenho, vimos tanto a mentalidade institucional - práticas e virtudes quanto o desenho institucional - instrumentos dispositivos e constitutivos. Agora passaremos à última seção deste capítulo, os "delimitadores" do desempenho, referente aos limites institucionais de uma corte. Esta terceira variável corresponderá exatamente ao contexto institucional (2.3.1) e às circunstâncias institucionais (2.3.2), isto é, ao "jurídico" e ao "político".

\section{Estruturação do modelo avaliativo}

Primeiro nível $=$ Fases + Capacidades + Tarefas
Segundo nível $=$ Práticas + Virtudes + Instrumentos
Terceiro nível $=$ Contexto + Circunstâncias


Como dito, finalmente alcançamos o último nível do modelo avaliativo: a variável dos "delimitadores" do desempenho (2.3). Embora não esteja disposto no modelo original, organizamos os elementos extraindo seus principais componentes. ${ }^{67}$ Fornecemos a cada um dos elementos, tanto do contexto jurídico quanto das circunstâncias políticas, um rol com suas disposições normativas seguindo a linha dos "facilitadores" (2.2).

$\mathrm{Na}$ primeira parte deste terceiro nível, trataremos das fronteiras jurídicas da adjudicação constitucional. Segundo Mendes, um modelo de desempenho deliberativo precisa iluminar e regular as razões aceitáveis em um fórum deliberativo. Afinal, o direito não seria contrário à deliberação, mas instituiria um controle formal sobre a argumentação devido ao raciocínio político sob o Estado de direito ser enquadrado por limites jurídicos. Para o autor, este aspecto trata do cânone argumentativo o qual faz a legitimidade das decisões compreenderem várias fontes ou discursos. (MENDES, 2013).

Vejamos as fontes de argumentos constitucionais responsáveis pela substância jurídica no processo decisório de uma corte deliberativa. ${ }^{68}$

\footnotetext{
${ }^{67}$ Sobre a questão da interpretação constitucional, enfatizamos a probletização feita em SILVA, Virgílio Afonso da. Interpretação constitucional e sincretismo metodológico. In: Virgílio Afonso da Silva (org.). Op. Cit.. Segundo o autor, em 2005, "a interpretação constitucional pressupõe uma discussão acerca da concepção de constituição, da tarefa do direito constitucional, da interação da realidade constitucional com a realidade política do Brasil e, ainda, acerca da contextualização e da evolução histórica dos institutos constitucionais brasileiros. É necessário [desenvolver a] teoria constitucional brasileira". Sobre esta questão no STF, indicamos SILVA, Virgílio Afonso da. Interpretação conforme a constituição: entre a trivialidade e a centralização judicial. Rio de Janeiro: Revista Direito GV, n. 1, v. 2, jan.jun. 2006, pp. 191-210. Para o autor, o cânone interpretativo de "interpretação conforme a constituição" adquiriu espaço na jurisprudência do STF e na argumentação forense em geral, embora tanto a fundamentação quanto as consequências deste cânone sejam mais problemáticas do que aparentam ser perante a legislação brasileira.

${ }^{68}$ Recomendamos a tese de doutoramento em Direito, pela Universidade de Brasília (UnB) e a Universidade de Alicante (UA), de André Rufino do Vale, "Argumentação Constitucional: um estudo sobre a deliberação nos Tribunais Constitucionais", orientada por Claudia Rosane Roesler e Manuel Atienza Rodríguez, em 2015 (ver nota 46). Suas ideias se relacionam às de Mendes.
} 


\subsection{Os delimitadores do desempenho deliberativo}

\subsubsection{O contexto institucional}

Para Mendes, o papel constitucional seria isolar um conteúdo substantivo fundamental de uma discussão aberta e desenfreada, pois estaria na essência das constituições modernas proteger normas não-negociáveis. Em sua visão, portanto, o ponto da deliberação constitucional não seria negociar em que medida a constituição se mostra comprometida, mas sim uma maneira mais proficiente e desejável em construir a constituição ao invés de descobrir em que a constituição implicaria. (MENDES, 2013)

Desse modo, segundo o autor, uma corte deliberativa reconheceria abertamente a qualidade moral da linguagem constitucional; forjaria um liame jurisprudencial coerente ao seu estoque de precedentes; desempenharia a função de coordenação interinstitucional em relação aos tribunais inferiores; se veria como participante de uma contínua conversação entre os poderes; e apreciaria o ideal constitucionalista como um empreendimento cosmopolita. (MENDES, 2013)

\section{Elementos contextuais}

Razões jurídicas

"Linguagem constitucional"

"Precedentes"

"Tribunais inferiores"

iv. Deliberação entre poderes "Legislativo e Executivo"

v. Reverberação cosmopolita "Jurisprudência estrangeira" 


\section{Abordando fontes jurídicas}

Diante do quadro acima, o raciocínio constitucional de uma corte deliberativa será delineado sem aprofundar controvérsias sobre os métodos de interpretação. Para o autor, embora não se trate de uma teoria interpretativa plena, existiria uma teoria minimalista de raciocínio subjacente as limitações jurídicas. Almejando o desempenho deliberativo, Mendes indica diferentes estratégias de interpretação sobre as limitações jurídicas estarem abertas à discussão entre os decisores. (MENDES, 2013)

De acordo a sua tese, a corte precisaria se comprometer a uma determinada abordagem de suas fontes jurídicas antes de abraçar um método particular. Esse argumento se insere em uma etapa anterior a deliberação e estabelece como a instituição deve assimilar suas fontes jurídicas. Nessa linha, a qualidade das razões invocadas, além de como os deliberadores interagem, será importante na avaliação do desempenho deliberativo. (MENDES, 2013)

Para Mendes, esta avaliação não precisaria adotar um padrão substantivo de correção e nem uma receita interpretativa completa. Segundo o seu raciocínio, uma corte deliberativa deve procurar orientar uma concepção de direito a qual seja hospitaleira a deliberação. Assim, a linha entre razões jurídicas e não-jurídicas, ou o perímetro da formalidade do direito, poderia ser desenhado em diferentes lugares. (MENDES, 2013)

$\mathrm{Na}$ tentativa de indicar gêneros de argumento constitucional capazes de aumentar o potencial deliberativo da corte, a lista abaixo desenha parcialmente essa linha. Para Mendes, quanto mais uma corte rejeitar esta lista, menor será o seu potencial deliberativo em relação à amplitude de razões possíveis. Assim, por mais intensa que seja a interação argumentativa entre os deliberadores, a deliberação constitucional não alcançará todo seu potencial se as razões disponíveis não forem justas quanto à complexidade jurídica e política de uma determinada controvérsia constitucional - casos fáceis e casos difíceis. (MENDES, 2013) 


\section{i. Qualidade moral da linguagem}

\section{"Linguagem constitucional"}

a) leitura moral da constituição;

b) limites ao textualismo;

c) reconhecimento do poder interpretativo.

Segundo o autor, o constitucionalismo incorporou a linguagem dos fundamentos constitucionais em conceitos morais abstratos, mas textos constitucionais incluiriam inúmeras disposições além de seus fundamentos. Para Mendes, as implicações institucionais devem ser consideradas na distinção entre disposições constitucionais abstratas e disposições constitucionais precisas. Afinal, em democracias constitucionais haveria uma semelhança entre esta generalização e o próprio estilo da redação constitucional. Em sua visão, leis ordinárias não-constitucionais poderiam incluir linguagem abstrata, mas suas implicações para a política e para a adjudicação seriam diferentes. (MENDES, 2013)

Mendes compreende direitos e normas estruturais anunciados por intermédio de princípios vagos e sucintos, mas em consequência, a condição política dos indivíduos, e até certo ponto do mecanismo operacional de governo, receberem pouco preenchimento substantivo de textos constitucionais. Dessa maneira, a responsabilidade em abastecer a norma de conteúdo suplementar seria concedida a autoridades constituídas e existiriam formas mais ou menos deliberativas em exercê-la. A medida em que o escrutínio constitucional é exercido dentro desse pano de fundo normativo, uma abordagem deliberativa requer franqueza ao caráter contestatório desses conceitos morais abstratos. Para o autor, o raciocínio constitucional sincero dependeria da divulgação de uma teoria da justiça encontrada na raiz de qualquer reivindicação política. (MENDES, 2013) 


\section{Um fundamento de legitimidade}

Segundo Mendes, a divulgação reflexiva permitiria avaliar a consistência de uma teoria da justiça. Esta abordagem seria chamada de "transparência e sinceridade", pois seu fundamento de legitimidade é a disciplina do argumento. Para o autor, se trataria de um compromisso institucional em não fazer o que não se esteja preparado a justificar mediante argumentos os quais satisfaçam as condições básicas de "transparência e sinceridade". (MENDES, 2013)

De acordo a este pensamento, essas duas condições abasteceriam a confiança no poder do argumento de modo a restringir a interpretação jurídica, pois o vício da má decisão residiria em argumentos ruins e convicções inaceitáveis. Logo, a saída seria apontar como e onde os argumentos se mostraram ruins e as convicções se tornaram inaceitáveis, atualizando uma abordagem a qual se mostra prejudicial ao potencial deliberativo ao negar que decisores constitucionais se aprofundam em considerações morais. (MENDES, 2013)

Para o autor, a política constitucional seria corrompida pela pretensão de decisores usarem estratégias neutras de interpretação. Assim, ao tentarem ocultar a inevitável influência de suas próprias convicções, os fundamentos reais da decisão seriam destituídos da legítima inspeção e do valioso debate público. Segundo Mendes, esse desafio demonstraria o costume em se utilizar argumentos de valor angariando a necessidade em esclarecer de forma tão completa e precisa o quanto decisores poderiam basear seus próprios juízos. (MENDES, 2013)

Mendes, por isso, adere ao ideal de leitura moral da constituição defendendo uma atitude interpretativa em relação ao texto constitucional. Nesse sentido, os decisores deveriam exibir uma consciência teórica ativada, pois uma cultura jurídica a qual sombreia os dilemas substanciais fundamentais renuncia à possibilidade de uma deliberação aberta na arena da interpretação constitucional. (MENDES, 2013) 


\section{a) leitura moral da constituição}

Como vimos, decisores os quais estimam prosperar com a deliberação não podem ocultar os juízos morais solicitados pelos textos constitucionais. Para Mendes, ignorar a responsabilidade dessas escolhas na aplicação da constituição seria uma prática enganosa. Uma jurisprudência constitucional ruim, portanto, deixaria os decisores sem prestarem contas de seus juízos. Segundo o autor, movimentos para fundamentar julgados em uma 'intenção original' ou em 'regras de linhas claras' nascem de uma negação da própria essência de um decisor. Esta descrição, na visão de Mendes, demonstraria a inevitabilidade da escolha moral entre os bens constitucionais. Para o autor, desejos emparelhados nesses bens poderiam se chocar e quando o fizessem a corte seria forçada a escolher entre eles. Assim, a instituição precisaria decidir qual deles possuiria o maior clamor e ao realizar esse tipo de escolha a corte deveria fazer mais que interpretar de maneira justa. (MENDES, 2013)

\section{b) limites ao textualismo}

De acordo a tese de Mendes, o limite do escrutínio constitucional deliberativo seria determinado pela forma como a linguagem constitucional é tratada. Uma corte a qual não consiga escapar ao textualismo - entendido como a busca não-volitiva de significados ocultos sob palavras escritas -, estaria vulnerável à objeções. Segundo o autor, a deliberação não pode ser enquadrada por uma "camisa de força formalista". O textualismo seria uma estratégia conveniente para a legitimação judicial. (MENDES, 2013)

Nesses termos, Mendes sustenta que as declarações claras sobre a aplicação de regras inculcarão no público a impressão de serem a vontade coletiva aplicada de forma neutra, mas cortes constitucionais administrarão instituições deliberativas quando puderem abandonar a bagagem herdada de tradições as quais tentaram separar os fundamentos jurídicos da moral ao buscarem "higienizar" a aplicação do direito. (MENDES, 2013) 


\section{c) reconhecimento do poder interpretativo}

Segundo o autor, a viabilidade da tomada aberta na interpretação constitucional seria uma questão de história política e não uma questão de teoria normativa. Para Mendes, tradições jurídicas poderiam ser avessas à reflexividade visada pela deliberação, mas uma cultura política madura referente ao raciocínio constitucional não deveria ser surpreendida pela bússola do poder interpretativo de uma instituição encarregada em aplicar a constituição. Assim, o reconhecimento aberto desse poder se mostraria uma condição de fundo para também mantê-lo em xeque. (MENDES, 2013)

\section{ii. Profundidade histórica}

\section{"Precedentes"}

a) carga de coerência narrativa;

b) técnicas de seguimento de precedentes;

c) densidade jurisprudencial;

d) sensibilidade histórica.

Mendes afirma que uma postura contra o textualismo não supõe a ausência de controle interpretativo sobre o texto constitucional e tampouco pressupõe decisores deliberativos como moralistas os quais simplesmente consideram sua moralidade e nada mais. Para o autor, essa postura aceitaria o texto como um ponto de partida na busca do significado constitucional, perfazendo assim um campo de jogo documental voltado a um tipo restrito de compromisso moral. Segundo Mendes, o caráter normativo do direito constitucional, especialmente em relação à disposição de sua textura tipicamente aberta, não poderia ser esgotado pelo texto constitucional. Sob esta visão, o texto constitucional forneceria um idioma compartilhado perante as reivindicações políticas. (MENDES, 2013) 


\section{a) carga de coerência narrativa}

No modelo avaliativo, apesar de alguma aderência normativa ao texto constitucional, as cortes constitucionais não estariam desprovidas de outros fundamentos textuais para decidir. $\mathrm{O}$ arquivo de precedentes criaria uma carga de coerência narrativa derivada do princípio geral de decidir conforme casos semelhantes. Para Mendes, o arquivo de decisões passadas determina grande parte do significado constitucional e também executa uma restrição crucial. Assim, uma corte deliberativa estaria comprometida à coerência e responsabilidade pelas decisões anteriores. (MENDES, 2013)

\section{b) técnicas de seguimento de precedentes}

Ainda, segundo Mendes, o contexto ético no qual precedentes operam seria moldado por um ideal de equidade. Essa restrição se traduz em diversas técnicas de seguimento de precedentes e a escolha dessas técnicas forma distintos sistemas onde cada um deles adota um padrão particular de semelhança e força vinculante. Para o autor, esses sistemas ocupariam algum ponto no espectro entre um sistema de deferência estrita ao stare decisis horizontal e um sistema de vaga autoridade persuasiva. As técnicas de seguimento, portanto, variam de acordo a três fatores principais: o critério de identidade permitindo selecionar um precedente; o método para construir o holding ou a ratio decidendi dos casos futuros; e o peso normativo concedido ao próprio precedente. (MENDES, 2013) Vejamos.

\section{Principais variáveis para sistemas de precedentes}

critério de identidade seleção de caso

método de construção decisão de caso peso normativo posição de caso 


\section{c) densidade jurisprudencial}

Para Mendes, quaisquer que sejam as variáveis técnicas aprovadas por uma corte, seu potencial deliberativo pode ser reforçado por uma construção consciente de sua densidade jurisprudencial. Esta densidade consistiria no desenvolvimento de uma racionalidade incremental a qual seja prospectiva e retrospectiva, evitando uma "amnésia institucional", um reinício da história constitucional a cada novo caso. (MENDES, 2013)

Segundo o autor, a densidade jurisprudencial não ignora a interpretação se sujeitar ao desenvolvimento e à mutação, também não atribui uma deferência em branco a posições anteriores. A linha histórica continua clara mesmo quando um precedente é rejeitado. Um anexo crítico aos precedentes gera profundidade histórica para a tomada de decisão de uma corte sem inscrevê-los em uma posição estacionária. (MENDES, 2013)

Nessa concepção, como uma prática memorial, o seguimento de precedentes seleciona o que lembrar e o que esquecer. Nesse esquecimento, uma corte deliberativa não esconde a existência de um precedente, mas explica sua falta de sustentabilidade. Para Mendes, uma corte deliberativa sente a pressão por coerência e a enfrenta abertamente, é franca sobre os motivos de seguir ou anular um precedente e até que ponto os precedentes permanecem como uma razão independente para decidir. (MENDES, 2013)

Para o autor, além de uma restrição argumentativa, os precedentes ofertam a corte um repertório fértil de argumentos os quais podem ser revisados maximizando sua capacidade deliberativa e economizando sua escassa energia deliberativa. A corte se tornaria capaz de construir uma memória institucional ao reconhecer o valor de deliberações anteriores além de torna-la mais responsiva. Segundo Mendes, ao adotar uma abordagem crítica sobre seu passado, uma corte deliberativa mitigaria seu impulso conservador e evitaria ficar refém de dependências. ${ }^{69}$ (MENDES, 2013)

\footnotetext{
${ }^{69}$ Sobre esta questão, Mendes utiliza um conceito da literatura estadunidense: "path dependency”.
} 


\section{d) sensibilidade histórica}

Mendes sustenta que a stare decisis teria um pequeno espaço no direito constitucional. Para o autor, a constituição foi escrita para todos os tempos e todas as épocas. Assim, ela poderia perder seu caráter e se tornar débil se permitida a ficar incrustada em noções estreitas e legalistas as quais dominam o pensamento de uma geração. Segundo Mendes, uma abordagem normativa pragmática compete com uma abordagem coerente, considerando a coerência se preocupar com equidade enquanto a pragmática prioriza previsibilidade e certeza aos precedentes. (MENDES, 2013)

Dessa forma, uma corte a qual leva seus precedentes a sério consegue deliberar com seus próprios selfs passados e futuros. A corte se mostraria auto-reflexiva de maneira profundamente histórica. Para o autor, como a deliberação seria um processo de longo prazo, o acúmulo de precedentes e a experimentação oferecida a cada tópico deveriam realmente ampliar a qualidade epistêmica das decisões mais longevas da corte. (MENDES, 2013)

Nesse quesito, uma decisão escrita deliberativa manteria um valor epistêmico a medida em que fosse recebida como precedente por casos futuros. Mendes então sublinha a consideração de integridade baseada no conhecimento, pois a medida em que um ordenamento jurídico evolui de forma auto-consciente como um sistema, não como mera agregação de regras e casos sem qualquer exigência robusta de coerência interna, o ordenamento estará em posição de explorar efetivamente seu reservatório histórico e sistêmico de experiência e razão prática. (MENDES, 2013)

Para o autor, o lado oposto deste atributo seria uma reserva de precedentes suficientemente deliberada como um desincentivo justificado a novos exercícios deliberativos. Assim, a longevidade de uma controvérsia específica exerceria influência sobre a necessidade de novas deliberações. Segundo Mendes, portanto, a carga deliberativa seria mais recente e mais onerosa em casos de primeira impressão (casos dificeis). (MENDES, 2013) 
Em outra vertente, o autor sustenta que se a corte possuir uma sequência de precedentes correspondentes e considerar não haver nada de novo a declarar, os casos semelhantes não precisariam envolver uma deliberação demorada (casos fáceis). Para Mendes, o desafio a uma corte em aceitar bons precedentes, por isentarem de novas rodadas deliberativas, seria o de permanecer atenta às nuances trazidas por novos casos às controvérsias antigas. Afinal, cortes podem alcançar sólidas posições ao longo do tempo e não estarem interessadas em reabri-las. Simultaneamente, uma corte deliberativa precisaria manter sua sensibilidade histórica e evitar o risco em se cegar diante dela. (MENDES, 2013)

\section{iii. Coordenação intra-judiciária}

\section{"Tribunais Inferiores"}

a) relação argumentativa

b) input e output

Até agora, as duas limitações anteriores - qualidade moral da linguagem e sensibilidade histórica - transmitiram uma antiga controvérsia sobre a suposta fusão entre os valores de adequação e justiça. Para Mendes, estas limitações formariam um compromisso de comprometimento moral às substâncias jurídicas baseado nos profundos princípios os quais justificam todo o sistema. ${ }^{70}$ Dessa maneira, segundo o autor, embora as três limitações adicionais não sejam frequentemente consideradas como tal, elas também podem ser lidas à luz do ideal deliberativo. (MENDES, 2013)

\footnotetext{
${ }^{70} \mathrm{Em}$ termos de uma relação argumentativa, como veremos abaixo, Mendes indica que Barry Friedman destaca o aspecto político em Taking Law Seriously. Perspectives on Politics, n. 4: 261276, 2006. Para um panorama crítico do direito no Brasil, recomendamos a obra WOLKMER, Antonio Carlos. Introdução ao pensamento jurídico crítico. São Paulo: Saraiva, $2012-8^{\mathrm{a}}$ ed.
} 


\section{a) relação argumentativa}

Mendes enfatiza a relação de uma corte deliberativa com o sistema judicial não se basear apenas na autoridade hierárquica encapsulada por um mecanismo de stare decisis vertical. Esta relação seria argumentativa e assumiria uma forma especial, pois haveria mais na interação intrainstitucional que uma deferência hierárquica ou uma política judicial intracorporis. Segundo o autor, os argumentos fluiriam por intermédio de canais e seriam vitais na sustentação da coerência do sistema. (MENDES, 2013)

Já percebemos a existência de uma variação referente ao lugar onde as cortes constitucionais são posicionadas em relação ao resto do judiciário, sua localização institucional. Como vimos, a classificação mais comum seria entre o modelo estadunidense, com uma suprema corte colocada no topo do sistema recursal e o kelseniano, com as cortes constitucionais colocadas fora do poder judicial e habilitadas ao controle de constitucionalidade em abstrato. (MENDES, 2013)

Cabe mencionar que entre esses tipos ideais, sob as formas difusa e concentrada de revisão judicial, surgiram vários sistemas mistos, como é o caso brasileiro. Para Mendes, a diferença entre um sistema em que apenas a corte superior tem o poder de declarar a inconstitucionalidade de uma norma, como o tipo kelseniano, e um sistema em que os decisores inferiores também têm esse poder no caso concreto, como o tipo estadunidense, se mostra crucial para determinar a relevância e a intensidade dessa limitação. (MENDES, 2013)

Ou seja, na visão do autor, cada sistema judicial tem uma dinâmica interna particular. Em alguns, a restrição da comunicação intra-institucional pode não ser uma preocupação significativa e ainda assim, ao escolherem e justificarem seu curso de ação, muitas cortes encarregadas em operar o escrutínio constitucional terão a responsabilidade de levar em consideração os tribunais inferiores e suas futuras decisões. (MENDES, 2013) 


\section{b) input e output}

Para Mendes, esta limitação se manifestaria de duas maneiras: como uma questão de entrada (input), anterior ao recurso final, os casos constitucionais endereçados a corte podem provocar trocas argumentativas em decisões inferiores. Em outra via, como uma questão de saída (output), a decisão da corte terá impacto sobre a forma como as instâncias inferiores interpretarão e aplicarão a constituição dali em diante, independente da existência de stare decisis vinculante vertical. (MENDES, 2013)

Segundo o autor, uma corte deliberativa será obrigada a ouvir o que o sistema jurídico já produziu anteriormente (input) e comunicar suas decisões de forma a preservar uma linha histórica coerente (output). Isso seria mais que uma autoridade de coordenação interna do judiciário e mais que comandar a imposição de decisões específicas a partir do topo, pois envolveria comunicar a interpretação constitucional de maneira inteligível, persuasiva e gerenciável. (MENDES, 2013)

Na visão de Mendes, em alguns sistemas a corte exigirá enquanto em outros ela apenas sugerirá uma solução jurídica ao restante do poder judiciário. Para o autor, em ambas as circunstâncias, uma corte deliberativa seria obrigada a responder a argumentos os quais experimentaram vários tipos de soluções. Tal como acontece em seus próprios precedentes, ocorreria uma melhora do desempenho deliberativo ao se comprometer com decisões proferidas por outras instâncias judiciais. Apesar de incomum, a distinção entre "exigir" e "sugerir" não seria forçada. (MENDES, 2013)

Como exemplo, Mendes usa o sistema brasileiro pois ele não só instancia uma variante mista da dicotomia estadunidense-kelseniana, por causa da coexistência entre controle difuso e concentrado, como oferece discrição em determinar se sua decisão sobre um recurso final terá efeito vinculativo ou não. Esse efeito não seria operado pela decisão como um todo, mas por um "súmula vinculante" - uma breve declaração normativa a qual define a ratio decidendi do caso. (MENDES, 2013) 


\section{iv. Deliberação entre poderes}

"Executivo e Legislativo"

a) resposta tréplica à ação;

b) compromisso argumentativo;

c) doutrina de deferência;

d) postura institucional.

Segundo Mendes, a ideia de separação de poderes seria a de um aparato associado à dissipação de autoridade, uma marca institucional do constitucionalismo liberal. Esta separação colocaria em movimento uma engrenagem conhecida como freios e contrapesos, na qual instituições se controlariam sem a predominância de nenhuma delas. (MENDES, 2013)

Para o autor, a questão em saber se a separação de poderes equivaleria a uma divisão de funções, ou a um mecanismo de diversas forças sob controle, seria um debate antigo cuja lógica interna não se ajustaria bem ao estabelecimento de uma soberania interna fixa. No entanto, como requisito do moderno Estado de direito, o circuito decisório precisaria parar em algum momento e uma decisão deveria ser definida. Afinal, como esta teoria supõe, a legalidade não sobreviveria às disputas intermináveis de poder. (MENDES, 2013)

Na concepção de Mendes, uma certa persuasão democrática requer o público personificado dentro dessa estrutura. Para ele, essa afirmação iria de encontro a compreensão clássica do princípio da "soberania popular", o qual se refere à uma manifestação pré-institucional e não formalizada de "povo" capaz de subordinar a todos. Logo, esta afirmação indicaria parlamentos como candidatos naturais ao papel político e simbólico da supremacia constitucional tendo a legislação como principal fonte de autoridade legal, mas mesmo assim os atos legislativos ainda precisariam obedecer à constituição. (MENDES, 2013) 


\section{As teorias do diálogo institucional}

Segundo Mendes, seria necessária uma agência capaz de verificar a constitucionalidade das decisões parlamentares e esta função foi tipicamente atribuída a cortes constitucionais. Por conseguinte, quando se tratar do significado constitucional, as cortes tem a última palavra. Logo, o desafio político fundamental aos regimes organizados sob estas pedras angulares seria encontrar uma forma de articular os papéis de parlamentos e cortes sob os termos de coexistência e compromisso. Para o autor, esta versão sustentaria parte significativa dos debates sobre a revisão judicial. (MENDES, 2013)

As teses dialógicas, por sua vez, compartilhariam a posição da "última palavra" como uma preocupação exagerada de legitimidade política e parlamentos teriam a oportunidade, ao longo do tempo, de responderem ou não às decisões judiciais. Na visão do autor, isso se daria em modelos "fracos" de revisão judicial, onde a resposta legislativa é formalmente institucionalizada, e também em modelos "fortes", onde as respostas podem se esgueirar de maneira menos formal. (MENDES, 2013)

Para Mendes, as respostas legislativas à revisão judicial seriam possibilidades sempre presentes, tanto no atacado quanto no varejo e as circunstâncias políticas, ao invés do texto constitucional, explicariam melhor quando isso acontece. Em sua concepção, ao formularem inquéritos mais fecundos sobre as contribuições de cada poder a esse processo, as teorias dialógicas ignoram a questão da "última palavra" e refletem sobre os possíveis padrões de uma interação interinstitucional. (MENDES, 2013)

Em conclusão, há um contraste entre "deliberação-fim”, impondo a supremacia judicial, e "deliberação-indutora", convidando o legislativo a responder; entre "deliberação-respeitosa", concedendo à qualidade de argumentos legislativos, e "deliberação-protetora", resguardando as condições do debate público na revisão judicial. Nesses termos, se observa um tom o qual pode convidar ou não a esse diálogo. (MENDES, 2013) 


\section{a) resposta tréplica à ação}

$\mathrm{Na}$ visão de Mendes, os possíveis significados da constituição raramente dependem de quem tenha a exclusividade da "última palavra" e os significados emergem de um processo intrincado de resposta tréplica à ação. Assim, a interação entre a corte e o legislador seriam episódios de um jogo interativo o qual pode ser efetuado inúmeras vezes. Esse jogo revelaria um rosto sub-explorado da separação de poderes: ao lado da disputa de forças, haveria, ou poderia haver, uma troca de razões. Em outras palavras, incidiria uma tensão política e deliberativa nesse circuito as quais coexistem e moldam a tomada de decisão coletiva. (MENDES, 2013)

Segundo o autor, essa dupla face contra-intuitiva captaria as facetas defensiva e construtiva da separação de poderes, reconhecendo a existência de vida política após a "última palavra" e defendendo o diálogo como um meio mais atraente em disciplinar essa interação interminável. Para Mendes, a supremacia judicial desencadearia um monólogo unilateral, um respeito geral deferente ao fórum de princípios. Já a responsabilidade judicial, por sua vez, exigiria um diálogo bilateral em que a corte poderia ser uma "Ágora de Princípio". Afinal, uma corte não poderia falar sozinha, sendo relevante melhorar o outro lado dessa conversa. (MENDES, 2013)

$\mathrm{Na}$ tese do autor, o princípio da separação de poderes expressaria um fato a ser percebido - a provisoriedade da decisão coletiva ou a continuidade da decisão política - e um ideal a ser perseguido - um modo de interação deliberativo. Segundo Mendes, esta tentativa em atingir um ponto de equilíbrio entre a "última palavra" e o diálogo a longo prazo certamente não será desprovida de dificuldades. Dessa maneira, uma teoria de diálogo consistente não estaria isenta de enfrentar questões sobre quando é justificável um poder atacar os atos de outro, onde a "última palavra", mesmo provisória, deveria ser colocada e, sobretudo, o que esta divisão de trabalho deveria ser. Para Mendes, uma sugestão de resposta a esta questão estaria baseada justamente sob o contexto decisório. (MENDES, 2013) 


\section{b) compromisso argumentativo}

Para o modelo avaliativo, a separação de poderes pode ser sensível a razões. Em sintonia com a ideia de deliberação de poderes, esta cultura da supremacia judicial sobre o significado constitucional restringiria a oportunidade de cidadãos aderirem à deliberação. Para Mendes, um papel judicial responsável deveria abdicar desse monopólio e incentivar os outros a participarem dos julgamentos sobre os valores fundamentais da sociedade. Esta característica poderia ser entendida como uma restrição de direito a qual exerce influência sobre as cortes. (MENDES, 2013)

Segundo o autor, o desempenho deliberativo na sobreposição de espaços ocupados por parlamentos e cortes seria uma medida útil mediante a qual a interação poderia ser regulamentada e criticada. Cada participante dessa interação carregaria responsabilidades deliberativas e uma corte deliberativa se comprometeria às razões providas pelos outros poderes. A corte avaliaria os respectivos desempenhos e, nessa base, decide se deveria desafiá-los com melhores razões. Na visão de Mendes, a redundância funcional parcial entre parlamentos e cortes pode ser benéfica se entendida e praticada por intermédio das lentes deliberativas. (MENDES, 2013)

$\mathrm{O}$ autor então enfatiza que a atenção de uma corte à deliberação interinstitucional implicaria na rejeição da supremacia judicial absoluta, uma visão a qual não considera os atos legislativos como autênticas interpretações constitucionais. Para Mendes, uma corte deliberativa não se compreende como a "última palavra" sobre a constituição. Em um contexto de interação contínua, uma corte abordaria o parlamento como um agente a ser persuadido, mas o qual também poderia persuadir em retorno. Segundo esta tese, se estimularia uma troca deliberativa em vez de um jogo de soma zero entre vencedores e perdedores. Assim, os poderes seriam autorizados a se desafiarem desde que escutassem e apresentassem novas razões. Nesta conta, as cortes não atuariam apenas como um contra-poder, mas também como um contra-argumento. (MENDES, 2013) Esta é a proposta. 


\section{c) doutrina de deferência}

$\mathrm{Na}$ formulação do autor, mais concretamente, junta-se ao percurso deliberativo da separação de poderes a construção de uma doutrina de deferência baseada no desempenho deliberativo. Essa doutrina informaria uma revisão judicial pautada na "deliberação-respeitosa" cujo padrão judicial de deferência seria autoimposto. Assim, todos os casos em que as cortes decidem revogar uma decisão legislativa também seriam casos em que as cortes decidem não se obrigam a se submeterem ao poder legislativo. (MENDES, 2013)

Segundo Mendes, o prazo de cada caso decidido pela corte nem sempre poderia ser enquadrado com a extensão da persuasão coletiva ou interinstitucional. Para o autor, a persuasão demandaria argumento, mas também poderia requerer uma experimentação do mundo real somente permitida pela passagem do tempo. Afinal, a persuasão poderia exigir mais que uma única rodada deliberativa, pois as decisões coletivas emergentes de cortes constitucionais ou de parlamentos seriam obras comunitárias em andamento e uma decisão judicial seria apenas o segmento de um diálogo público contínuo ou de um diálogo em andamento. (MENDES, 2013)

Conforme a tese do autor, uma relação dialógica seria inerente à constituição. Para Mendes, o pressuposto subjacente é haver uma conversa civilizada e não um discurso grosseiro entre os poderes. De acordo ao modelo avaliativo, o estágio exato e a qualidade da conversa, portanto, seriam variáveis relevantes para se determinar quando adiar e se retirar ou quando continuar pressionando por novas razões e rodadas de discussão. Segundo o autor, as noções de "palco" e de "qualidade" dessa conversa demandariam maiores qualificações, mas a intuição básica seria a do escrutínio constitucional poder ser exercido em diferentes contextos, cada um dos quais ofertando uma possibilidade em aumentar os encargos argumentativos e as razões de legitimidade. Dessa maneira, o contexto decisório se vê moldado por diferentes variáveis. (MENDES, 2013) 
Para Mendes, essas variáveis seriam a época da norma, por ser diferente anular uma norma promulgada há gerações de uma norma atual promulgada com novos argumentos; a qualidade deliberativa da norma, por normas de codificação abrangente penetrarem a cultura normativa e institucional de forma mais robusta que normas expedientes e de curta duração; a sua relação com a omissão ou comissão parlamentares, pois preencher o vácuo de inércia legislativa não é o mesmo que revogar uma norma; e os chamados casos de segunda vista, nos quais a corte avalia uma espécie de resposta legislativa e provoca o debate sobre a qualidade dessa vista ser motivo suficiente para a sua submissão. Segundo o autor, esse tipo de submissão enfrentaria recusas pois um diálogo entre parlamentos e cortes não deveria ser degradado por uma regra de "se não conseguir, tente novamente" e também haveriam criticas por se ficar preso ao próprio precedente em um caso de segunda vista. (MENDES, 2013)

Mendes alega que a corte pode não se envolver em novos motivos legislativos e enviar ao congresso uma mensagem desafiadora a qual caracterizaria uma típica postura de supremacia judicial. Como percebemos, dificuldades práticas surgem na tentativa de implementar o ideal de conversação entre poderes. Afinal, por diferentes mecanismos formais, parlamentos e cortes convertem múltiplas vozes em uma e para uma corte ingressar em um diálogo identificando argumentos por trás das normas, pode acabar flertando com entidades mistificadoras tais como a "intenção original" ou a "vontade do legislador". (MENDES, 2013)

Segundo Mendes, as doutrinas de deferência praticadas de forma semelhante em várias jurisdições seriam moldadas pelas preocupações indicadas até aqui. Assim, uma corte deliberativa perceberia a separação de poderes de maneira particular, não de maneira modesta e autossuficiente, mas curiosa e aberta aos argumentos que possam ser contrários ou a favor de suas posições. Isso posto, um senso de falibilidade e provisoriedade, portanto, só poderia ser ajustado mediante esta concepção de separação de poderes. (MENDES, 2013) 


\section{d) postura institucional}

Finalmente, a rejeição da própria existência da revisão judicial como escolha de desenho institucional se curvaria à maneira como ela é exercida. Para Mendes, se evitaria combinar a revisão judicial com a supremacia judicial e se consideraria a supremacia como uma postura particular no exercício da revisão em si. Assim, a noção de postura se torna iluminadora e captura o que está em jogo por haver um erro em definir o que implica uma postura de supremacia. A supremacia teria a ver com a postura adotada pela corte - e o respeito concedido a essa postura - quando demandas sobre a constituição estivessem claras. (MENDES, 2013)

Segundo o autor, a supremacia judicial poderia ser representada como a postura da corte ao se recusar a olhar para além da substância jurídica. Isto é, uma recusa a tomar qualquer orientação do legislativo, do executivo ou das resoluções plebiscitárias do povo quanto à forma como uma escolha enfrentada pela corte deve ser resolvida. Nesse limiar, a corte usufruiria da sua aura de legalidade para silenciar outras vozes nas esferas públicas formal e informal. Desse modo, para Mendes, a deliberação de poderes atenderia exatamente a essa preocupação por prezar uma corte a qual esteja em sintonia com as deliberações externas demarcando de forma adequada o seu espaço. (MENDES, 2013)

\section{v. Reverberação cosmopolita}

"Jurisprudência estrangeira"
a) nova fonte do direito;
b) ética do direito comparado;
c) senso de comunidade transnacional;
d) meta-princípio de autoridade;
e) ideal de conversa cosmopolita;
f) compromisso de capacidade de resposta. 
Para Mendes, a citação mútua transnacional não seria uma prática nova, mas continuaria sem uma imagem geral de quais princípios políticos a explicam, justificam e demandam. Dado este panorama, Mendes reitera o dever de um decisor em estar ciente dos precedentes estrangeiros mesmo deixando-os de lado. Nesse sentido, dilemas constitucionais passariam por diferentes tradições e contribuiriam a uma jurisprudência mundial mesmo quando substâncias jurídicas domésticas se mostrassem mais úteis. A partir disso, mediante a articulação de dois argumentos principais, o autor propõe um quadro normativo capaz de regular esse fenômeno. (MENDES, 2013)

No primeiro, o autor afirma o dever das cortes em identificar um ius gentium moderno na jurisprudência estrangeira: um conjunto de decisões convergentes a serem incorporadas como fonte de percepção. Para Mendes, ao cristalizar uma série de soluções comuns a problemas semelhantes, se terá um produto das experiências multinacionais repetidas. Neste entendimento, tal instituto não seria um "garantidor da verdade", mas estaria baseado na sabedoria acumulada em termos de direito e justiça. Assim, ele poderia ser visto como um equilíbrio reflexivo entre acordos provisórios de direito positivo e um senso de justiça, mas, de todo modo, será uma construção interpretativa. (MENDES, 2013)

No segundo, Mendes pressupõe o dever de uma corte em buscar a expansão global da integridade sob o domínio da jurisprudência de direitos fundamentais. Para o autor, as decisões estrangeiras não deveriam ser entendidas como precedentes vinculativos, mas sim como decisões dignas de algum peso independente de sua correção. Na visão de Mendes, ao compartilhar compromissos morais básicos, uma comunidade política deveria abraçar o ideal de integridade transnacional. De acordo ao autor, no entanto, este propósito não deveria significar a expansão do senso de agência, mas sim do senso de comunidade, pois a concepção de direito como razão prevaleceria sobre o direito como vontade. (MENDES, 2013) 
De acordo ao propósito de Mendes, a qualificação de comunidade global não se referiria à uma comunidade universal, mas sim à uma associação entre instituições dedicadas especificamente a avançarem sobre a ideia de direitos humanos. Nesse limite, caso decisões nacionais sejam fundamentadas em apelos às particularidades culturais, o autor alega que suas descontinuidades em relação às decisões estrangeiras poderão ser vistas como um empecilho em potencial. ${ }^{71}$ (MENDES, 2013)

Por fim, como o "principal significado" e demais "delimitadores" poderiam se preocupar, uma corte deliberativa não seria necessariamente cosmopolita e nem uma corte paroquial seria não-deliberativa. Mendes esclarece que com base na incoerência e na casuística, uma corte realmente pode prejudicar seu desempenho ao não considerar seu próprios precedentes, mas embora $\mathrm{o}$ ato de negligenciar a jurisprudência estrangeira possa conduzir à auto-exclusão de um esforço transnacional, esse tipo de prejuízo não estaria em jogo nessa modalidade. Mas, de toda forma, uma corte constitucional poderia aumentar sua capacidade deliberativa quando se mostrasse comprometida à jurisprudência comparada. (MENDES, 2013)

\section{a) nova fonte de direito}

Segundo a tese de Mendes, os motivos e a forma de comparação seriam questões cujas respostas não forneceriam orientações suficientes à uma preocupação diferente: "por que e como as cortes deveriam utilizar o direito estrangeiro como fonte válida de argumento jurídico?". Para o autor, estes dois níveis - comparação per se e comparação como auxílio à decisão - nem sempre se distinguem, mas ao permitir uma decisão estrangeira integrar sua ratio decidendi, a corte atribuiria algum tipo de autoridade jurídica à essa decisão e a comparação iria além de um hábito intelectual esclarecedor, fornecendo uma nova fonte de direito. (MENDES, 2013)

\footnotetext{
${ }^{71}$ Temos restistência às concepções do item. Ver resenha de Frank D. McCann (1991) sobre "The americanization of Brazil: a study of U.S. Cold War diplomacy in the Third World (1945-1954)".
} 
Para Mendes, seu reconhecimento ainda necessitaria seguir um meta-princípio de autoridade. Na percepção do autor, entre os diferentes tipos de autoridade presentes no cenário jurídico, tem-se o diálogo entre as cortes como produto de "consideração simpática". Segundo Mendes, esta consideração seria interpretada tanto pelo prisma cognitivo, observando pragmaticamente quais problemas a serem admitidos, quanto pela ambição das democracias constitucionais, compartilhando um fundamento moral capaz de tornar decisões estrangeiras dignas de peso. (MENDES, 2013)

A partir dessa possibilidade de diálogo, Mendes afirmará a incidência da ética do direito comparado sobre três princípios aplicáveis ao domínio da jurisprudência constitucional. Devido às suas especificidades, esses princípios serão refinados por camadas adicionais. (MENDES, 2013)

\section{b) ética do direito comparado}

Primeiramente, o princípio da auto-compreensão afirmaria uma identidade a corte devido a comparação trazer informações sobre seu perfil. Adicionalmente, a comparação também permitiria a percepção do próprio dialeto particular inserido em uma linguagem de direitos. Para Mendes, como a partir desta compreensão mais profunda sobre si se tornaria possível formular uma autocrítica, o princípio do auto-aperfeiçoamento, além de permitir reflexividade e induzir o aprimoramento moral, também refinaria este dialeto particular e incorporaria as nuances não observadas pelo princípio anterior. (MENDES, 2013)

Finalmente, o princípio da cooperação mútua apreciaria a integração em comunidade pelas comparações moralmente significativas assumirem um senso de parceria e reciprocidade. Em adição, este princípio capacitaria a construção de uma narrativa coerente diante de um esforço comum. Mendes pontua que a auto-compreensão e o auto-aperfeiçoamento assumiriam um caráter interior enquanto a cooperação mútua assumiria um caráter exterior. (MENDES, 2013) 
Diante dessa distinção acima, o autor detalha que embora o fenômeno jurisprudencial não se restrinja ao domínio dos direitos, suas disposições estruturais estarão sujeitas à correlação de forças da jurisdição local. Para Mendes, no entanto, embora a linguagem de direitos tenha uma tomada universalista, sua moral não estaria vinculada à jurisdição e por isso se tornaria mais fácil uma jurisprudência de direitos percorrer diferentes jurisdições ao contrário dessas disposições estruturais. (MENDES, 2013)

\section{c) senso de comunidade transnacional}

Segundo o autor, ao pretender harmonizar práticas de direitos nacionais, o esforço comum só faria sentido se um senso de comunidade transnacional fosse mantido. Para Mendes, essa harmonização implicaria em uma busca de consistência concebida como uma proposta aberta de razões a serem assimiladas enquanto uma restrição a decidir conforme casos semelhantes. Em decorrência, também se admite a necessidade em definir um critério sensível a esse contexto de "semelhança".

Seguindo esta linha, a ideia de consistência deve se dar sob uma propriedade sofisticada de razão prática capaz de permitir a distinção entre dissimilaridades as quais integram os raciocínios baseados em precedentes. Assim, ao compartilharem ideais políticos, cortes constitucionais deveriam se comprometer a um tipo de fertilização cruzada sem ignorar suas próprias peculiaridades locais. (MENDES, 2013)

\section{d) meta-princípio de autoridade}

Segundo Mendes, como salientado, o valor do direito comparado não justificaria de imediato a incorporação de substâncias comparativas pelas cortes nacionais, pois a possibilidade de uma jurisprudência de direitos transitar por argumentos acadêmicos ou políticos não legitimaria seu trânsito formal à decisão judicial. (MENDES, 2013) 
Para o autor, formas mais legítimas de internalizar soluções estrangeiras exigiriam razões normativas complementares capazes de articular um meta-princípio de autoridade. Em sua concepção, no raciocínio constitucional não bastaria a importância em aprender com a experiência e visão alheias. Nesses termos, enquanto o princípio de cooperação mútua trabalharia melhor mesmo sem suprir um requisito de legitimidade, os princípios de auto-compreensão e de auto-aperfeiçoamento não chegariam tão longe. (MENDES, 2013)

Como argumento adicional, Mendes então trará razões normativas complementares misturando três reivindicações: o Estado de direito e o constitucionalismo, pois ambos seriam permeáveis a um tipo de autoridade baseada na persuasão e não apenas na obrigatoriedade; a legitimidade democrática, pois além da votação por maioria situada no tempo e no espaço, implicaria o respeito às decisões coletivas nucleares baseadas em razões públicas; e o ideal cosmopolita, pois este demandaria um status moral igualitário para cada indivíduo, afetando o conteúdo das razões públicas. (MENDES, 2013)

\section{e) ideal de conversa cosmopolita}

Para o autor, um ideal de conversa cosmopolita acrescentaria substância a esse argumento adicional e forneceria um senso de direção. Segundo Mendes, juntando todos os elementos até aqui, este ideal seria uma derivação da ética do direito comparado aplicada à interação entre as cortes constitucionais. Assim, uma comunidade global de cortes emergiria desse processo não como conjunto de soluções constitucionais de cima para baixo, mas como uma corrente multilíngue conectada por um projeto moral compartilhado. Na compreensão de Mendes, como deu-se a entender, a participação nesse desenvolvimento seria uma opção a qual as cortes poderiam ou não realizar. (MENDES, 2013) 
Segundo o autor, algumas cortes poderiam preferir se concentrar em um diálogo regional ou em um diálogo com cortes incorporadas a tradições culturais e linguísticas mais próximas as suas. Nesses termos, para o autor, a singularidade contextual justificaria diversas soluções as quais não poderiam ser exportadas, mas na conversa cosmopolita um recurso ao contexto não libertaria as cortes de se comprometerem as razões ventiladas sobre um conjunto similar de dilemas morais. (MENDES, 2013)

Por outro lado, o autor também atenta a existência de riscos, pois o direito constitucional comparado não é uma atividade neutra. Em sua tese, o perigo de se converter esse exercício em um instrumento de opressão geopolítica não seria negligenciável. Diante desse risco, o autor afirma que termos de interação não poderiam ser definidos a priori pelos centros de poder político e intelectual sem o senso de reciprocidade exigido pela ética do direito comparado: a cooperação mútua. (MENDES, 2013)

Mendes alega que entre os pecados comparativos, a subserviência geopolítica em regimes constitucionais menos prestigiosos é um obstáculo crucial, como no STF. Para o autor, a história constitucional de "países em desenvolvimento" seria permeada por uma atitude reverente em relação às cortes canônicas, mas esses países (ex.: Brasil) não deveriam funcionar como plataformas de recepção passiva importando soluções constitucionais de plataformas de produção ativa. Seria preciso ver o estrangeiro como um parceiro e não como uma autoridade moral e política. (MENDES, 2013)

\section{f) compromisso de capacidade de resposta}

Finalmente, segundo Mendes, o valor a ser destacado não seria apenas epistêmico, mas político: a exibição de uma disposição associativa em integrar uma cadeia deliberativa mais ampla. Para o autor, portanto, uma parceria implica em comunidades se reconhecerem como membros de um esforço único e assumirem a responsabilidade em fazer o melhor possível para construírem uma narrativa compartilhada. (MENDES, 2013) 
No entendimento de Mendes, um juízo sobre as comunidades se reconhecerem como "parceiras" seria constitutivo. Para o autor, uma corte a qual assimila o ideal cosmopolita seria susceptível a enriquecer seu potencial deliberativo. Assim, o desafio trazido por esta fonte não seria quantitativamente diferente dos outros listados até aqui. (MENDES, 2013)

Para Mendes, uma corte deliberativa contrairia o ônus em promover julgamentos atentos a este reservatório multidirecional de argumentos. Esses julgamentos, no entanto, não se ajustariam ao sistema jurídico aceitando mecanicamente qualquer argumento, mas se ajustariam sim por um compromisso de capacidade de resposta em relação a esses argumentos. Ao mesmo tempo, porém também seria percebida uma tensão entre a exploração desta fonte de recursos argumentativos e o ideal de integridade. (MENDES, 2013)

\section{Limites institucionais: o contexto institucional}

Como vimos, os 5 (cinco) elementos revelam fontes de argumentos constitucionais a serem consideradas na decisão escrita deliberativa e correspondem à amplitude de razões disponíveis aos decisores. Estas razões ensejam um comprometimento moral às substâncias jurídicas baseado em princípios os quais justificam todo o ordenamento jurídico. Como atestado, em casos difíceis, provavelmente, mais fontes jurídicas precisarão ser utilizadas pela corte e por isso estas limitações, ou restrições, perfazem o contexto jurídico de uma corte constitucional.

Concluída esta primeira subseção, entraremos nas circunstâncias institucionais. Embora essas circunstâncias sejam predominantemente políticas, também incidem circunstâncias deliberativas. Estas se referem às condicionantes da corte para iniciar um processo deliberativo e requisitam uma deliberação prévia. Iniciaremos a parte final do capítulo tratando deste exame de pré-condições, ou seja, três testes de circunstâncias deliberativas envolvidos em uma deliberação de segunda ordem. 


\subsubsection{As circunstâncias institucionais}

Para Mendes, a política circundante adicionaria certos ingredientes importantes à deliberação. Em sua visão, esses ingredientes diriam respeito aos testes prudenciais e interpretativos oferecidos por uma deliberação de segunda ordem. Segundo o autor, esse tipo de deliberação prévia aceitaria exceções sob a clareza da deliberação de primeira ordem não se mostrar recomendável, seja por seus custos serem elevados, seja pela simples tentativa acarretar em colapso. (MENDES, 2013)

Como visto, no modelo avaliativo do autor o reconhecimento de circunstâncias deliberativas supõe que contextos abaixo do ideal requerem padrões diferentes de conduta. Mendes então sustenta que em cenários não ideais a deliberação seria contraproducente e a formulação de um conceito de circunstância justificaria quando decisores são impedidos de deliberar, além de esclarecer as tensões a serem tratadas em cada caso concreto. (MENDES, 2013)

Segundo o autor, para sabermos em quais circunstâncias uma certa comunidade deveria investir escassos recursos políticos na deliberação e como estimar se a própria deliberação seria possível, consequente e conveniente, três testes seriam capazes de detectar um contexto hostil ou favorável à deliberação. Assim, ao sopesar as perdas e ganhos do processo deliberativo, deveriam ser testadas: as condições do grupo de trabalho; a existência e o tipo de desacordo; e o nivel de urgência. (MENDES, 2013)

\section{Testes de circunstâncias}

Primeiro teste condições do grupo de trabalho

Segundo teste existência e tipo de desacordo

Terceiro teste nível de urgência 


\section{Circunstâncias deliberativas}

No teste sobre as condições do grupo de trabalho, seria necessário perguntar quanto valeria a pena se arriscar. Consistiria em investigar até que ponto as promessas deliberativas simplesmente desmoronam, ou se diferentes promessas e riscos deliberativos poderiam se desenrolar simultaneamente, justificando alguma compensação. (MENDES, 2013)

Já o teste sobre a existência e tipo de desacordo deveria observar se apesar de um acordo aparente, haveria algum valor em retomar a deliberação de modo a manter os argumentos vivos e protegê-los de incorrerem em "dogmas mortos". O último teste verificaria se o nivel de urgência de uma decisão supera os benefícios putativos da deliberação. Este corolário moldaria as circunstâncias deliberativas e destacaria quando a deliberação seria requisitada ou se encontraria isenta. (MENDES, 2013)

Para Mendes, os três testes trazem a crença na deliberação ser realizada desde que alguns riscos sejam retirados e sua conveniência seja mensurada. Em seu entendimento, a deliberação poderia ser mal empregada sob um comportamento insensível diante das condições políticas reais. Assim, o fluxo de pensamento político ajudaria a criar instituições que clonam um cenário ideal ao preencherem condições prévias. Após um equilíbrio, se deve concluir a possibilidade da deliberação ocorrer de forma não incendiária ou destrutiva; de forma consequente e não fútil; e de forma oportuna e gratificante, não temporária ou distrativa. (MENDES, 2013)

Segundo o autor, esses testes se resumiriam a identificar o ponto de inflexão no qual a insistência na argumentação deixa de ser útil. O nível de urgência e o grau de relevância do assunto podem indicar diversas soluções quanto a quantidade de deliberação desejável. Para Mendes, em certos contextos, a alternativa poderia ser menos deliberação combinada à uma compensação adaptada ou alguma forma de votação silenciosa; em outros, poderia ser aconselhável até mesmo ficar sem a perspectiva imediata de uma decisão. (MENDES, 2013) 


\section{Circunstâncias políticas}

Para Mendes, devido as circunstâncias deliberativas vistas acima tratarem das restrições políticas do escrutínio constitucional, uma noção de corte como estrategista política deve ser elaborada. Desse modo, segundo o autor, caberia a instituição verificar, em cada uma dessas circunstâncias, qual seria o melhor caminho para manutenção de seus propósitos políticos. Logo, seguem abaixo as principais variáveis extrajurídicas compondo um menu das escolhas estratégicas a serem feitas pela corte. (MENDES, 2013)

\section{Elementos circunstanciais Estratégias políticas}

vi. Tempo de resposta "Definição de agenda e arquivo"

vii. Amplitude, profundidade e tom .. "Conteúdo decisório"

viii. Grau de coesão "Decisão escrita"
ix. Cooperação entre poderes "Compatibilidade de agendas"
x. Gestão da opinião pública "Fases pré e pós-decisória"

$\mathrm{Na}$ tipologia de Mendes, escolhas estratégicas internas seriam o momento do julgamento, incluindo a definição de agenda e sua duração; o estilo de julgamento, atravessando questões de amplitude, profundidade e tom; e as mensagens simbólicas por trás das decisões individuais ou plurais. Em outra linha, escolhas estratégicas externas envolvem o nível de intrusão nos outros poderes; e o afastamento da corte diante da opinião pública. ${ }^{72}$ (MENDES, 2013)

\footnotetext{
${ }^{72}$ Gostaríamos de sublinhar, por exemplo, o ocaso das relações políticas entre membros de uma corte constitucional e agentes econômicos privados: as atividades de seus membros fora da corte.
} 
Para Mendes, uma corte constitucional desconhecedora de tais restrições poderia se tornar vulnerável aos possíveis assaltos externos. Sob esta concepção, a corte poderia se arriscar em conflitos desnecessários e retrair-se gradualmente, mas se a instituição planeja aproveitar todo o seu potencial deliberativo, não pode deixar de participar desse jogo. Segundo o autor, ao participar, no entanto, a corte não precisaria comprometer sua independência e imparcialidade judicial, ao invés disso poderia se tornar ainda mais capacitada a preserva-las. (MENDES, 2013)

$\mathrm{Na}$ tese de Mendes, um conflito institucional seria político no sentido de estar enraizado em manter ou aumentar a autoridade judicial. Este conflito não se encontra necessariamente ligado às normas de legalidade. Para o autor, portanto, as escolhas a respeito dessas variáveis refletirão um perfil político, o que Mendes identificará por “considerações institucionais". Segundo sua visão, em qualquer sistema político, a busca por autoridade expansiva conflita com o interesse de agentes políticos capazes de diminuir a autoridade e essa busca seria "temperada" por essas “considerações institucionais". (MENDES, 2013)

\section{vi. Tempo de resposta}

\section{"Definição de agenda e arquivo"}

a) senso de prioridade;

b) senso de oportunidade.

De acordo ao modelo avaliativo, o tempo de resposta judicial manifesta-se em dois momentos: primeiro a corte se pergunta quando a deliberação deve começar, incorporando um caso à agenda e demarcando os atos processuais subsequentes; depois se pergunta quando deve terminar, tomando uma decisão a seu respeito. (MENDES, 2013) 
Segundo Mendes, esta seria uma variável fundamental na teoria constitucional. Para o autor, essa variável não-jurídica poderia ser encerrada pelo desenho institucional ou convencionada de antemão. Mendes alerta que uma jurisdição obrigatória e um prazo para decidir poderiam restringir ou mesmo abolir essa discrição. Em sua visão, muitas cortes constitucionais com um poder discricionário relativo, tanto à ordem do dia quanto à uma margem de manobra processual para adiar ou acelerar o julgamento, podem calibrar a temperatura política de seu arquivo de casos. (MENDES, 2013)

Para o autor, um critério padrão de equidade temporal - como ordem de chegada, por exemplo - nem sempre seria adequado para ordenar casos e atender suas respectivas urgência ou susceptibilidade políticas. $\mathrm{Na}$ percepção de Mendes, cortes constitucionais poderiam criar instrumentos para manter o debate na agenda pública por um longo tempo, estimulando a publicação da decisão em porções graduais e permitindo outros atores intercederem enquanto a corte permaneceria em silêncio. (MENDES, 2013)

Segundo Mendes, haveria uma conexão entre o senso de tempo e o palco da conversa entre os poderes. Para Mendes, muitas vezes um caso chegaria cedo demais ou mesmo quando não houvesse mais nada a ser dito. Por esse motivo, se apontaria o tempo de resposta como variável relevante a deliberação. Em sua visão, esta seria a etapa em que os decisores concluem chegar o momento de não persistirem mais no silêncio. (MENDES, 2013)

Mendes cita o caso do Supremo Tribunal Federal brasileiro acerca do desenvolvimento de uma complexa mistura de diversas alternativas para prolongar a duração de um determinado caso. ${ }^{73}$ Segundo ele, a corte poderia tomar uma decisão "preliminar" e adiar a decisão "definitiva" por anos ou mesmo suspender a sessão de julgamento após a solicitação de um decisor. Neste intervalo, sublinha o autor, o debate público alternaria momentos de ruído e de silêncio na esfera pública. (MENDES, 2013)

\footnotetext{
${ }^{73}$ Ver, por exemplo, o caso da ADPF $\mathrm{n}^{\circ}$ 59, a qual trata da auditoria da divida pública brasileira, arguida em 06/12/2004 pelo Conselho Federal da OAB e sem enrar em pauta há quinze anos.
} 


\section{a) senso de prioridade}

Logo, Mendes aponta uma corte deliberativa possuir um senso de prioridade para responder ao invés de buscar indefinidamente a melhor resposta. Para o autor, uma corte poderia ser sensível à duração de um caso de duas maneiras: diante do impasse, reconhecendo quando a deliberação não permitiria maior persuasão ou não houvesse nenhum benefício em prover razões; ou aceitando a urgência e os custos de atraso superarem os potenciais benefícios da deliberação, mesmo havendo algum espaço para transformar preferências ou refinar argumentos. (MENDES, 2013)

Segundo Mendes, a deliberação estaria a serviço de melhores decisões e algumas vezes a urgência do caso não permitiria uma exploração completa dos potenciais da deliberação. Assim, um inquérito sobre a deliberação ser viável, produtiva e oportuna, além da busca pelo seu montante ideal, serão responsabilidades primárias. (MENDES, 2013)

\section{b) senso de oportunidade}

$\mathrm{Na}$ tese de Mendes, como tempo e energia são recursos escassos, prioridades precisam ser definidas. Em sua visão, um senso de oportunidade poderia ajudar a decidir quando a corte deve avançar ou recuar, pois às vezes menos é melhor que mais deliberação. Segundo o autor, uma corte deliberativa seria oportunista ao entender o impulso apropriado para suas decisões. Em outras palavras, a corte seria estratégica para lidar com suas “dinamites políticas". (MENDES, 2013)

Para Mendes, o momento do caso seria uma das determinantes entre as repercussões desencadeadas por uma decisão judicial. Em sua tese, algumas ocasiões poderiam ser melhores que outras e desde que houvesse um critério a esse respeito, uma corte deliberativa deveria gerenciá-lo mediante cálculos políticos. Em sua percepção, como já ventiladmos, esta "decisão sobre quando decidir" seria uma das escolhas entre deliberações de segunda ordem. Aliás, a primeira delas. (MENDES, 2013) 


\section{vii. Amplitude, profundidade e tom}

\section{"Conteúdo decisório"}

a) minimalismo judicial;

b) maximalismo judicial;

c) modo retórico particular;

d) estratégia de comunicação.

Assim, uma vez resolvidos os dilemas ocasionais de agenda e duração, Mendes enfatiza a necessidade em refletir sobre como comunicar a decisão. Para o autor, parte dessa questão envolveria delinear a amplitude, a

profundidade e o tom decisórios. Depois de "decidir que deve decidir" a corte precisaria equilibrar os termos da decisão e essas escolhas também estarão imbuídas de ressonância política. Segundo Mendes, a corte chega à conclusão de ser a hora em confrontar e a única questão será quão amplo é seu domínio e a profundidade analítica a determiná-lo. (MENDES, 2013)

Para Mendes, amplitude e profundidade atenderiam ao avanço de uma teoria minimalista da revisão judicial. Mendes compreende a dimensão da amplitude operar em escala horizontal, direcionando a variedade de casos futuros a qual o caso alcançará como precedente. Ainda, segundo o autor, a dimensão da profundidade estaria em uma escala vertical, referente ao nível de abstração das bases da decisão. Em sua visão, este arranjo dependeria de grandes princípios minutarem as razões de casos específicos. (MENDES, 2013)

\section{a) minimalismo judicial}

O minimalismo judicial, portanto, seria a prática em não dizer mais que o necessário para justificar um resultado, deixando indecisas a maioria das questões discutíveis acerca do caso. (MENDES, 2013) 
De acordo a tese de Mendes, se contemplariam decisões estreitas e não amplas, além de superficiais e não profundas. $\mathrm{O}$ minimalismo judicial facilitaria a produção de "acordos incompletamente teorizados", os quais permitiriam decisores discordarem sobre os princípios, mas concordarem sobre os resultados. Na percepção do autor, além de uma técnica para reduzir desentendimentos, o minimalismo estimularia a deliberação pública por meio de um "uso construtivo do silêncio". (MENDES, 2013)

Segundo Mendes, haveria mais para a adjudicação constitucional que a declaração de constitucionalidade ou inconstitucionalidade, pois as maneiras de praticar esse poder dificilmente seriam disciplinadas por lei. Para o autor, essas maneiras de se defender uma postura judicial específica articulariam as categorias de amplitude e profundidade decisória. Ainda assim, Mendes enfatiza uma corte deliberativa não ser tão confiante sobre os efeitos putativos do silêncio, pois embora destaquem-se seus potenciais propósitos por razões pragmáticas e estratégicas, estudar o que decisores dizem ainda seria tão importante quanto perceber o que eles não dizem, especialmente no caso do Supremo Tribunal Federal. (MENDES, 2013)

\section{b) maximalismo judicial}

Diante do quadro, Mendes considera, em algumas circunstâncias, a exigência do maximalismo judicial ao invés de abraçar completamente o minimalismo. Segundo o autor, a questão entre decidir de forma mínima ou máxima, um dilema entre solucionar problemas no presente ou estabelecer amplos padrões regulatórios no futuro, continuaria a ser um tópico para uma deliberação caso a caso. Para Mendes, no entanto, os escopos vertical (profundidade) e horizontal (amplitude) dos efeitos da produção legislativa resultante da decisão dependeriam dessa escolha. Nesse limite, se afirmará a importância para o constitucionalismo de common law da distinção entre a legislação como uma norma ampla, geral e abrangente e a adjudicação como uma norma restrita e limitada aos casos. (MENDES, 2013) 


\section{c) modo retórico particular}

Além de amplitude e profundidade, Mendes alega que o tom decisório seria um fator estratégico significante para intenções deliberativas externas. Segundo o autor, os decisores poderiam convergir sobre o grau de amplitude e profundidade, compartilhando conceitos e princípios jurídicos na afetação da controvérsia, mas ainda seria politicamente sensato escolher as palavras para expressar ou qualificar o que se pretende transmitir. Para Mendes, decidir o tom de voz implicaria um julgamento político agudo. Tanto a potencial ressonância vocal das decisões quanto as mensagens enviadas via obiter dicta, se tornariam outra variável a ser administrada. Esta fará referência, em outras palavras, ao lado retórico do escrutínio constitucional. (MENDES, 2013)

Segundo Mendes, para algumas vertentes, a retórica estaria em desacordo a deliberação por ser útil enganar e manipular a audiência, apelando a paixão à custa de um compromisso racional. $\mathrm{Na}$ concepção do autor, um certo tipo de retórica seria, de fato, uma ameaça a deliberação e a própria democracia. Para ele, este tipo retórico se destina exclusivamente a "obter a fidelidade de seu ouvinte independente dos meios e motivações fundamentais". Para o autor, se contrastam um tipo retórico plebiscitário e um tipo retórico deliberativo, o qual "coloca as emoções a serviço da argumentação franca". Na tese de Mendes, a retórica plebiscitária seria estrategicamente focada na obtenção de números, enquanto a deliberativa se concentraria em envolver, persuadir e informar cidadãos. (MENDES, 2013)

Mendes também estabelece a retórica, enquanto forma com que um argumento é comunicado em paralelo ao seu conteúdo, como inerente a qualquer interação comunicativa e a deliberação não poderia ser esterilizada contra ela. Em sua percepção, a compreensão do papel da retórica na comunicação política seria importante porque o significado de um discurso, a sua operação pragmática em uma situação de interação comunicativa, dependeria tanto de aspectos retóricos quanto assertivos. (MENDES, 2013) 
Para Mendes, mesmo o tom seco e especializado do discurso jurídico, seja em algumas áreas do direito ou em tradições do raciocínio jurídico, não precisaria ser visto como anti-retórico, mas como um modo retórico particular e não necessariamente ilegítimo. Na visão do autor, de qualquer forma, a linguagem constitucional tenderia a ser muito menos hospitaleira ao modo retórico tradicional. Um discurso desapaixonado imitaria a neutralidade e poderia excluir vozes inaptas a falar com o mesmo sotaque. Essa reivindicação, segundo Mendes, teria uma alavancagem especial no domínio do escrutínio constitucional, pois o que se exigiria como expressão neutra, universal e desapaixonada traria nuances retóricas de posições e de relações sociais específicas. (MENDES, 2013)

\section{d) estratégia de comunicação}

No modelo proposto pelo autor, uma decisão escrita deliberativa contrairia o compromisso em responder aos "clamores racionais" que thes são dirigidos e o tom de resposta traria um ingrediente político inevitável. Segundo Mendes, algumas tradições jurídicas possuiriam estilos de escrita tão arraigados que esta discrição evaporaria. $\mathrm{Na}$ visão do autor, entretanto, essa restrição seria definida por um cânone cultural e não por intermédio de um desenho institucional. (MENDES, 2013)

Mendes aponta que a corte precisaria escolher entre várias formas de frasear uma resposta a qual julga correta. Para o autor, o papel da deliberação não terminaria quando uma decisão fosse tomada e a escolha da maneira em falar ao público externo seria uma onerosidade residual. Mendes indica que se a corte pretende desempenhar um papel deliberativo consciente, requer uma estratégia de comunicação pública. Esta estratégia se relacionaria a amplitude, a profundidade e o tom, pois a corte modularia a competência do precedente produzido, graduaria a abstração de suas razões e melhoraria sua retórica. Assim, haveriam circunstâncias as quais convidariam a maiores ou menores formulações vocais. (MENDES, 2013) 


\section{viii. Grau de coesão}

\section{"Decisão escrita"}

a) acordo e desacordo;

b) exibição pública de divisão interna;

c) unidade e pluralidade.

O autor reforça que os formatos per curiam ou seriatim não seriam indicadores definitivos de uma interação colegiada. Na tese de Mendes, um critério formal não conseguiria compreender a qualidade deliberativa da decisão escrita e muito menos das fases precedentes, mas apesar disso ele permaneceria em jogo. Segundo o autor, caso a escolha discricionária do formato escrito não esteja impedida por regras institucionais, a corte teria a oportunidade em aprofundar suas considerações antes de selecionar qual o grau de coesão a ser documentado e exibido ao público. (MENDES, 2013)

\section{a) acordo e desacordo}

Na visão de Mendes, as decisões unânimes ou por maiorias, com concorrências e divergências, carregariam múltiplos simbolismos a serem explorados de acordo com as peculiaridades dessas circunstâncias. Para Mendes, variações de amplitude e profundidade também poderiam ser usadas como formas de reduzir o desacordo e alcançarem uma maioria ou unidade viáveis. Com efeito, essas variações moldariam o tipo de coesão. Assim, a manifestação da institucionalidade orgânica mediante uma opinião única favoreceria a segurança jurídica como propriedade formal do Estado de Direito. Segundo Mendes, além dessas razões de princípio, o formato único tenderia a obter maior força política, denotando autoconfiança na interpretação da lei e podendo exigir uma deferência mais ampla em relação a corte. (MENDES, 2013) 
Para o autor, o somatório de individualidades não obedeceria ao padrão, mas cortes poderiam preferir a manutenção do desacordo interno por razões estratégicas. Por outro lado, a imagem de neutralidade oferecida por uma única opinião poderia ser percebida como um valor em si e também uma arma mais dura a ser usada como estratégia de sobrevivência em face de prováveis resistências externas. (MENDES, 2013)

\section{b) exibição pública de divisão interna}

Mendes também alega que a fragmentação revelaria a resiliência do desacordo interno podendo estimular maiores debates e expor abertamente as incertezas formatadoras do caso. Na visão do autor, esse formato poderia transmitir respeito aos decisores dissidentes e concorrentes, além dos interlocutores. Nesse sentido, a corte enviaria um sinal sobre a possibilidade da maioria de seus decisores estar equivocada. Afinal, um consenso artificial nem sempre se mostraria vantajoso (MENDES, 2013).

Segundo o autor, por intermédio de uma exposição pública de desacordo, a corte poderia fazer eco a vozes ignoradas na opinião única. Assim, a demonstração escrita do esforço deliberativo poderia superar o valor da opinião única. Para Mendes, contudo, essa linha tênue envolveria o risco da instituição ser percebida como se travada por um combate mortal, onde números absolutos e não a força do melhor argumento controlariam o resultado. Grosso modo, esta seria a negociação política. (MENDES, 2013)

Em algumas circunstâncias, Mendes acredita ser melhor conceder a uma voz única ao custo de silenciar divergências e restringir-se a um denominador comum abaixo do alcançável pela maioria. Em outras, um pronunciamento de voz múltipla poderia aprofundar a deliberação externa. $\mathrm{O}$ autor supõe que quando a energia deliberativa de primeira ordem seja drenada sem acordo, haveriam razões de segunda ordem de um tipo político capazes de promover compromissos e elaborarem uma opinião per curiam ou deixarem uma decisão seriatim tomar lugar. (MENDES, 2013) 


\section{c) unidade e pluralidade}

Conforme vimos, a corte escolheria, entre a unidade e pluralidade, qual o grau de coesão politicamente louvável. Segundo Mendes, a tensão entre uma imagem pública de concórdia ou discórdia seria uma questão técnica, jurídica e política. Na visão do autor, a unidade favoreceria a tarefa estável da produção de regras no Estado de Direito e protegeria melhor a corte contra a pressão política. (MENDES, 2013)

Mendes também afirma que a pluralidade poderia ser vista por dois prismas. Do ponto de vista de princípios, concederia maior reconhecimento a plausibilidade das posições derrotadas e estimularia novas rodadas de deliberação pública, mas incorreria em deixar a lei indefinida. Do ponto de vista pragmático, dissidências poderiam encorajar interlocutores vencidos a persistirem em seu esforço de persuasão mediante novos casos, mas em algumas circunstâncias também poderiam encoraja-los a reagirem de forma menos institucional. (MENDES, 2013)

Segundo o autor, neste sentido, as opiniões divergentes poderiam desempenhar um papel político ao permitirem a decisão concordar com as maiorias externas. Para Mendes, a corte enviaria uma mensagem sobre a direção a ser perseguida no futuro e a decisão atual poderia ser lida como um compromisso momentâneo. Este compromisso, por sua vez, convidaria à mobilização pública para a corte efetuar uma mudança mais profunda em casos posteriores. (MENDES, 2013) Passemos agora as escolhas externas.

\section{ix. Cooperação entre poderes}

\section{"Compatibilidade de agendas"}
a) separação de poderes;
b) desenho de espaços;
c) flutuação de limites. 
Segundo a tese do autor, até aqui uma corte poderia evitar, atrasar, ou tomar parte em certos casos por meio do poder em definir sua agenda; também poderia aliviar ou intensificar a repercussão retórica por meio de sua liberdade em elaborar as decisões; e poderia ser um corpo orgânico ou dividido comunicando-se por meio de decisões únicas ou plurais. Mas, além disso, a corte poderia se afastar de decisões intrusivas ou, contrariamente, interferir e colidir com as posições de outros atores. (MENDES, 2013)

Assim, para Mendes, os tópicos anteriores descreveriam variáveis formais a serem medidas politicamente e esta medida deveria ser calculada de acordo com a maneira como uma corte antecipa as reações dos principais vetores das forças políticas externas: os demais poderes de governo e a opinião pública. (MENDES, 2013)

\section{a) separação de poderes}

O autor estabelece que uma "cooperação entre poderes" assimilaria a complexidade política de como os poderes interagem. Essa "cooperação" não sugere ingenuamente a ausência de conflito, mas discerne aspectos interdependentes da separação de poderes. Para Mendes, a tendência em conceber este arranjo como uma luta puramente adversarial, a competição pela supremacia constitucional ou a última palavra, ofuscaria a forma como políticas públicas emergem. Desse modo, a corte não teria poder para fazer valer suas decisões e precisaria da ação conjunta dos outros poderes para suas decisões se efetivarem. (MENDES, 2013)

Na tese de Mendes, uma “cooperação" combinaria decisões e nãodecisões, ações e omissões, sístoles e diástoles, baseadas nas acomodações prudenciais de interpretação jurídica, política e de princípio. A separação de poderes e outras limitações estruturais também poderiam ser pensadas como uma "cooperação" na qual cada poder ou unidade governamental teria um papel especial a desempenhar, mas seus objetivos não poderiam ser avançados a menos que trabalhassem em conjunto. (MENDES, 2013) 


\section{b) desenho de espaços}

A deliberação de poderes, como vimos no contexto jurídico, transmitiria o ideal de alavancar uma interação contínua por razões. Para Mendes, essa imagem seria complementada pela intrincada disputa oriunda de produções conjuntas. Apesar do conflito, isso não poderia ser feito sem negociação e compromisso mútuos. Na visão do autor, a lógica interna de freios e contrapesos dificilmente poderia ser capturada por um plano abstrato definido com antecedência e as linhas entre cada poder seriam redesenhadas constantemente. Em vez de se basear nas barreiras normativas consagradas pelo diploma legal, seu mecanismo de limitação seria concreto e existencial: os poderes contestam uns aos outros para demarcar o seu próprio espaço. (MENDES, 2013)

\section{c) flutuação de limites}

Dessa maneira, conflitos e ajustes entre instituições, e não a simples obediência às regras escritas, descreveriam melhor esse processo de demarcação. Segundo Mendes, a corte precisaria reconhecer que não pode ir a qualquer lugar conduzida apenas pelo texto constitucional, pois os limites do escrutínio flutuariam com os ventos da política. Para o autor, sem a colaboração dos outros poderes, a corte torna-se impotente e o recurso ao texto constitucional seria inútil quando outras forças políticas se tornassem robustas o suficiente para descumpri-lo. (MENDES, 2013)

\section{x. Gestão da opinião pública}

"Fases pré e pós-decisória"

a) radar da opinião pública;

b) interação com a opinião pública. 
No modelo de Mendes, a opinião pública não seria apenas uma restrição política, mas também se referiria à adjudicação em si. Segundo o autor, teorias da adjudicação constitucional já ofereceram diretrizes sobre como processar a opinião pública enquanto uma questão de princípio, mas não de política. Para Mendes, uma corte teria o dever em interpretar a constituição de acordo com o estado da opinião pública em evolução. No lado oposto, a opinião pública deveria ser ignorada para os direitos e a estrutura constitucional não serem colocados em risco. O autor também esclarece que a própria ideia de corte como bastião de direitos baseia-se na sua capacidade em se isolar contra tais forças. Afinal, se a corte fosse inevitavelmente subordinada à opinião pública, não haveria muito sentido no escrutínio constitucional. (MENDES, 2013)

\section{a) radar da opinião pública}

Paralelamente, segundo Mendes, a opinião pública poderia ser um grande fardo na autonomia para decidir. Por esse motivo, ter um radar sobre a opinião pública ajudaria a definir quais direções a corte poderia seguir. Para o autor, sem compensar decisões impopulares com decisões populares, a opinião pública poderia se tornar um fator de impedimento a capacidade executória da corte. (MENDES, 2013)

Como exemplo, Mendes aponta a Suprema Corte dos Estados Unidos por raramente "adotar um tom surdo ao humor público". Segundo o autor, esta corte nunca se afastou do público e na maioria das vezes permaneceu em sintonia mesmo contra o parlamento. Logo, as conexões empíricas entre a opinião pública e as decisões constitucionais poderiam ser visualizadas de forma bidirecional. Inicialmente, Mendes alega a possibilidade em estudar como decisões afetam a opinião pública. Assim, sobre esta perspectiva, a opinião pública poderia permanecer indiferente, mudar a favor ou se voltar contra a decisão da corte. (MENDES, 2013) 
Mas, para Mendes, a opinião pública como restrição política também se relaciona em uma direção causal inversa. Ou seja, ela não diz respeito ao efeito real de uma decisão já tomada sobre a opinião pública a partir de então, mas sim como as tendências pré-decisórias da opinião pública afetariam e moldariam a decisão judicial. Segundo o autor, indicar o quanto uma decisão deveria se afastar da opinião pública atual estimaria o impacto a ser promovido e a capacidade da corte em enfrentar esse impacto se mostraria o cálculo político em jogo. (MENDES, 2013)

De acordo ao modelo, as variáveis básicas a serem consideradas quando se classifica a opinião pública seriam: o tipo de caso em questão, podendo variar entre um endosso difuso a instituição e o suporte específico ao caso; o prazo - curto e longo -, e seu alcance, no qual as instituições construiriam um capital político difuso a ser gerenciado em decisões específicas mais ou menos populares. (MENDES, 2013)

\section{b) interação com a opinião pública}

Segundo o autor, a opinião pública - tanto em seu estado bruto pré-decisório quanto na forma como a corte prevê sua reação a uma decisão - não seria algo que se possa ignorar, pois o preço político de negligencia-la seria caro. Para Mendes, sempre há o risco em se perder a estatura política. Uma força política bruta poder debilitar a credibilidade da corte seria um dado a ser processado e respondido argumentativamente. (MENDES, 2013)

Por isso, segundo o autor, uma corte deliberativa não se submeteria à opinião pública sem se envolver com ela. Para Mendes, seria possível projetar, mediante decisões individuais, grandes esferas de verificação constitucional e determinar se decisões futuras poderiam se aprofundar na mesma linha de ação. Observar estes sinais permitiria a corte aproveitar ao máximo seu poder político e argumentativo. Assim, uma corte deliberativa deveria ser politicamente sensível e estar ciente sobre as circunstâncias não ideais tornarem a deliberação demasiado arriscada. (MENDES, 2013) 


\section{Limites institucionais: as circunstâncias institucionais}

Por fim, precisamos conferir uma aplicação prática às prescrições políticas. A corte, enquanto autoridade judicial, é um agente político e isso envolve a expansão de sua autoridade institucional. Diante do momento em que sua respeitabilidade moral estiver em jogo, a corte precisará enfrentar a possibilidade de manutenção, aumento ou mesmo de diminuição dessa autoridade. Segundo o autor, os inevitáveis conflitos institucionais não estarão necessariamente ligados às normas de legalidade e requisitarão "considerações institucionais". Essas "considerações" formariam o perfil político da corte e suscitariam as escolhas estratégicas propostas acima. ${ }^{74}$

Essas 5 (cinco) restrições políticas se unem às 5 (cinco) restrições jurídicas formando os "delimitadores" do desempenho e correspondendo aos seus limites institucionais. Após a descrição, finalizamos nosso segundo capítulo e a partir de agora vamos apresentar as conclusões acerca de nosso objeto: as competências deliberativas. Ao descrevê-las sob a forma de um tipo ideal o qual estrutura seu equipamento crítico, forma-se um guia capaz de aprofundar análises sobre cortes constitucionais: um mapa deliberativo.

\footnotetext{
${ }^{74}$ Como procuramos expor em outros trechos deste trabalho (ver nota 54 por exemplo), a atuação dos ministros se apresenta como um ponto de preocupação às comunidades juridica e polítca no Brasil. Durante a mais recente crise institucional no país, as críticas de Conrado Hübner Mendes ao STF, em 28/01/2018, renderam respostas diretas, como a da Ministra-Presidente à época, Carmén Lúcia, em reportagem de Leandro Colon para a seção Poder do jornal Folha de S. Paulo, em 30/01/2018: "Exposição de ministros leva a questionamento, diz Carmén sobre crítica ao STF"; e também do próprio Ministro Luis Roberto Barroso, no dia 23/02/2018, em artigo para a coluna Ilustríssima da Folha de S. Paulo: “'Operação Abafa' tenta barrar avanços do STF, escreve Barroso". Sobre essa íntima relação entre o modus operandi do STF e o modus vivendi de seus ministros, recomendamos as polêmicas matérias jornalísticas do experimentado Luiz Maklouf Carvalho para a seção Questões Jurídicas das edições 47 e 48 da Revista Piauí, em agosto e setembro de 2010, respectivamente: "Data vênia, o Supremo - Como funciona e o que acontece no STF" e "O Supremo, quosque tandem? - A indiciação dos juízes, os pedidos de vistas, os conflitos de interesse, o ativismo e as disputas entre ministros - a agenda de dificuldades do STF". Nesse sentido, para uma reflexão, recomendamos PASQUINO, Pasquale. Prolegômenos a uma Teoria do Poder Judiciário: o conceito de independência judicial na Teoria e na História. São Leopoldo: Revista de Estudos Constitucionais, Hermenêutica e Teoria do Direito, n. 2, v. 2, 2010 (em inglês).
} 


\section{CONCLUSÃO}

\section{O desempenho do Supremo Tribunal Federal}

No início deste trabalho perguntamos como as cortes constitucionais podem ser analisadas. Mendes nos respondeu com um mecanismo teórico de análise a partir do estabelecimento de um determinado tipo de corte constitucional ideal. Em seguida, perguntamos como este mecanismo seria capaz de avaliar o desempenho de uma corte constitucional, no caso o STF. Tendo em vista este propósito, descompactamos o modelo de Mendes para melhor explica-lo e agora precisamos compacta-lo novamente formando um guia explicativo. Para isso, recorreremos às primárias noções de realidade $\mathrm{e}$ potencialidade do desempenho deliberativo.

\section{Realidade}

Agente resultante tarefas deliberativas "Principal"

Agente resultante razões jurídicas "Delimitadores" Agente resultante estratégias políticas "Delimitadores"

Conforme nossa proposta inicial, contemplamos três padrões gerais de desempenho: contestação pública, interação colegiada e decisão escrita deliberativa. Diante desses três padrões, descrevemos 42 (quarenta e dois) indicadores em 5 (cinco) razões jurídicas; 5 (cinco) estratégias políticas; 9 (nove) práticas deliberativas; 8 (oito) virtudes deliberativas; 10 (dez) instrumentos dispositivos; e 5 (cinco) instrumentos constitutivos. As tarefas correspondem ao propósito institucional; as razões e as estratégias aos limites institucionais; as práticas e virtudes à mentalidade institucional; e os instrumentos à arquitetura institucional. O real versus seu potencial. 


\section{Entre normas e reformas}

Assim, conforme exposto no início do segundo capítulo, a realidade do desempenho será impactada diretamente pela própria potencialidade e é esta potencialidade, tendo em vista possíveis análises institucionais do STF, a qual desejamos explorar neste último capítulo.

\section{Potencialidade}

Agente causal práticas deliberativas "Facilitadores"

Agente causal virtudes deliberativas "Facilitadores" Agente causal instrumentos dispositivos "Facilitadores" Agente causal instrumentos constitutivos "Facilitadores"

Como sugerido, o modelo de Mendes parece apontar a mentalidade e o desenho institucional como componentes-chave ao desempenho. Dessa forma, práticas e virtudes da corte correspondem ao advento de normas deliberativas e os instrumentos reforçam reformas institucionais capazes de otimizar essas práticas e virtudes. Seguindo esta percepção, o projeto institucional, sua base, estaria ligado aos instrumentos constitutivos, enquanto o desenho institucional se desdobraria a partir dele.

No caso do Supremo, a dimensão de "projeto" pode ser apreendida em diversos sentidos, inclusive político. Neste sentido, haveria uma relação entre um projeto institucional e os projetos pessoais de seus membros. Por outro lado, o "projeto deliberativo" visto nesta monografia contempla a possibilidade de se construir uma melhor arquitetura de legitimação política em relação à função institucional do Supremo e a atuação de seus membros. Mas decorre uma nova pergunta sobre esta tese: como realizar um conjunto de reformas institucionais e implementar normas deliberativas no STF? 


\section{"Supremo arquiteto institucional"}

Esta pergunta tende a enfatizar o quanto a mentalidade institucional, evidenciada nas práticas e nas virtudes institucionais, vê-se afetada por questões de projeto e desenho institucional. Uma arquitetura de legitimação surge exatamente dessa dinâmica. Logo, diante desta arquitetura, os pilares do modelo ajudariam a desvelar uma integração estrutural. A nosso ver, a integração entre propósito, mentalidade, arquitetura e limites institucionais, a qual pode melhor informar o comportamento institucional do STF, também abastece criticamente o debate sobre reformas institucionais.

Projetar e desenhar instrumentos, no entanto, sugerem um "arquiteto de legitimação" igualmente responsável por elevar a proposta de reformas. A partir de nossa interpretação do modelo, colocamos em questão "quem" seria o responsável pelas reformas institucionais do STF. O ideal do autor em "transformar um tribunal de solistas numa orquestra" parece requisitar alguma moldura mais específica sobre a figura deste "regente" ou de como se daria a construção desta "regência". Uma pista à esta questão poderia ser extraída a partir das diferentes experiências internacionais. ${ }^{75}$

\footnotetext{
${ }^{75}$ Em BEZERRA, Rafael. Op. cit. "[...] a partir da insistência do então Chief Justice da Suprema Corte Americana, Warren E. Burger, em instituir uma organização [...] fora criado em 1971 o National Center for States Courts - NCSC. [Desde a] sua criação, constituiu-se em um agente catalisador da sistematização de informações e dados para a necessária reforma organizacional do sistema judicial americano. O NCSC, dentre outros objetivos, serviu [...] para identificar práticas exitosas; desenvolver experimentalismos judiciais e organizacionais; estabelecer normas e indicadores de avaliação de desempenho; instituir um fórum nacional para a discussão de questões [...]; apontar e pactuar uma agenda nacional para a melhoria da administração da justiça $\mathrm{e}$ promover a transparência". Em outra experiência, segundo Bezerra, "[...] na Finlândia, o processo de planejamento e estabelecimento de parâmetros de qualidade para a avaliação da jurisdição começou em 2003, como parte do Quality Project of the Courts, [na] definição de parâmetros de qualidade da adjudicação [...] em seis aspectos [e] com um total de quarenta critérios de qualidade". Ainda, segundo o autor, a Corte Constitucional Colombiana (CCC) seria um "exemplo de experimentalismo judicial que propiciou a avaliação do desempenho [...], bem como o monitoramento dos efeitos e impactos ocasionados nas demais instituições que compõem o sistema de justiça [e as] instituições governamentais e sociais envolvidas em litígios judiciais".
} 


\section{"Supremo professor deliberativo"}

De todo modo, os questionamentos sobre como realizar reformas e sobre quem contrairia essa responsabilidade abrem espaço a outras possibilidades metodológicas a partir do modelo. Como vimos, além do projeto/desenho, um ponto focal a se destacar seria a própria mentalidade institucional. No artigo mencionado em nossa introdução, "O projeto de uma corte deliberativa", o autor abre um espaço propositivo a essa questão:

Explicar ou apontar as causas do caráter [de uma corte
constitucional] demandaria uma análise minuciosa da interação
entre seus elementos procedimentais [instrumentos] e culturais
[mentalidade], uma combinação sempre intricada e dinâmica. (MENDES, 2012, p. 71)

Como procuramos indicar, o ethos institucional de uma corte recai sobre essa estreita relação entre instrumentos e mentalidade. Nesses termos, "cultura" pode ser lida como "cultura decisória", ou hábitos e costumes dos membros de uma determinada corte no desempenho da função institucional. Assim, para sabermos os traços de uma determinada cultura decisória, segundo Mendes, precisamos indagar sobre as "condições comportamentais para uma deliberação bem sucedida". ${ }^{76}$ Seu tipo ideal buscou apontar essas condições preenchendo parte de uma possível equação comportamental, mas como se formaria a cultura decisória do STF? Eis a nova questão.

\footnotetext{
${ }^{76}$ Consideração a partir de GAMBETTA, Diego. "Claro! An essay on discursive machismo". In: ELSTER, Jon (ed.). Deliberative Democracy. Cambridge, Cambridge University Press, 1998. Mendes mencionará Albert Hirschman, para quem o "deleite em ganhar um debate" requisita o "prazer em ser um bom ouvinte". Ver HIRSCHMAN, Albert. "Having opinions - One of the elements of well-being?". The American Economic Review, n. 79, v. 2, 1989. Como se aduz, faz-se necessário recorrer a abordagens sócio-culturais. Assim, ver ALMEIDA, Frederico de. A Nobreza Togada: as elites jurídica e a política da justiça no Brasil. Tese de doutoramento em Ciência Política pela Universidade de São Paulo (FFLCH/USP): São Paulo, 2010. Ver LC. 35 de 14/03/79.
} 


\section{Organizando informações}

Dito isto, reconhecemos a importância em traçar um mapeamento histórico e também um mapeamento sociológico envolvendo os decisores desta corte constitucional. Novas questões são levantadas a partir desse trabalho e novas pesquisas se mostram necessárias à comunidade jurídica. De acordo a esta conclusão, apontamos a necessidade em refinar e abastecer tanto o tipo ideal de corte constitucional quanto o modelo avaliativo de desempenho deliberativo de Mendes. Esta continua a nossa maior aposta.

Almejando contribuir metodologicamente aos futuros estudos de caso envolvendo esta corte, traçamos um mapa deliberativo para conciliar esforços de pesquisa, tanto quantitativos quanto qualitativos, como nas várias informações encontradas em diferentes projetos de pesquisa ao redor do Brasil. ${ }^{77}$ Reunir, organizar e agrupar todas essas informações sobre o STF é o sentido primordial para além da aplicação do próprio modelo.

Este mapa, acima de mensurar a qualidade da deliberação, pode orientar não só a aplicação do modelo de Mendes, mas pesquisas relativas a qualquer corte constitucional, incentivando estudos comparativos em cada uma das compartimentações que realizamos. Todos os parâmetros cunhados até aqui podem ser refinados e melhor apurados. Desse modo, a resultante de nossa pesquisa é um formato organizativo para que o modelo seja não apenas compreendido e aplicável, mas aprofundado em relação ao STF. ${ }^{78}$

\footnotetext{
${ }^{77}$ Projetos de pesquisa realizados pela Escola de Direito da Fundação Getúlio Vargas do Rio de Janeiro (FGV-RJ); pelo Conselho Nacional de Justiça (CNJ); e pela Escola de Direito da Fundação Getúlio Vargas de São Paulo (FGV-SP). Vale mencionar o workshop "Mare Incognitum: desafios da pesquisa empírica sobre o Supremo Tribunal Federal”, realizado em 2017 na Universidade de São Paulo (USP); e em 2018 na Fundação Getúlio Vargas do Rio de Janeiro (FGV-RJ).

${ }^{78}$ Cada vez mais há uma série de pesquisas sobre o STF. Organizar essas pesquisas e sistematizar suas informações pode contribuir em diversas frentes. Vemos as competências deliberativas de cortes constitucionais, os formatos de uma decisão escrita, por exemplo, como um ponto de partida e não como um ponto de chegada. Vale reforçar que o trabalho teórico de Mendes propicia uma plataforma de pesquisa para cortes constitucionais e não um mero "deliberômetro".
} 


\section{Formando o mapa deliberativo}

Como apontamos, o principal significado expressaria o núcleo da deliberação, tratando-se exclusivamente da deliberação de primeira ordem. Com efeito, este seria o processo decisório em sua plenitude, a performance sobre o objetivo da instituição em si, seu propósito e finalidade básicas: produzir uma decisão política coletiva. Mendes então prescreve três tarefas para suas fases estruturantes: a contestação pública (fase pré-decisória), a interação colegiada (fase decisória) e a decisão escrita deliberativa (fase pós-decisória). Assim, cada uma dessas três fases e suas respectivas tarefas possuiriam padrões normativos sobre as funções a serem desempenhadas pela corte. Estes padrões correspondem aos seus indicadores avaliativos.

Na sequência, o conjunto de facilitadores conformaria, de um lado, a mentalidade a ser desenvolvida pelos decisores em relação ao cumprimento dessas tarefas institucionais - suas práticas e virtudes deliberativas -, e de outro, os instrumentos institucionais - dispositivos e constitutivos - capazes de incentivar a realização dessas tarefas ou mesmo prejudica-las. Estes corresponderiam a arquitetura institucional da corte, seu projeto e desenho a ensejarem reformas institucionais de curto e longo alcances.

Por último, em uma deliberação de segunda ordem, os delimitadores integrariam as condicionantes do processo decisório, suas restrições, isto é, envolveriam um processo subjacente acerca dos limites relacionados ao contexto - razões jurídicas - e às circunstâncias - estratégias políticas - na deliberação, respondendo se a corte deve deflagrar o processo deliberativo ou não e quais seriam os empecilhos enfrentados pela instituição. Também envolveria o reconhecimento de elementos capazes de afetar uma tomada de decisão e as respectivas consequências para a imagem institucional.

A partir da esquematização do modelo, portanto, finalmente obtemos uma visão integral do dispositivo heurístico inaugurado por Mendes. Essa visão recobrirá os quatro aspectos da abordagem analítica sobre uma corte abarcando as variáveis de desempenho descritas ao longo de nosso trabalho: 


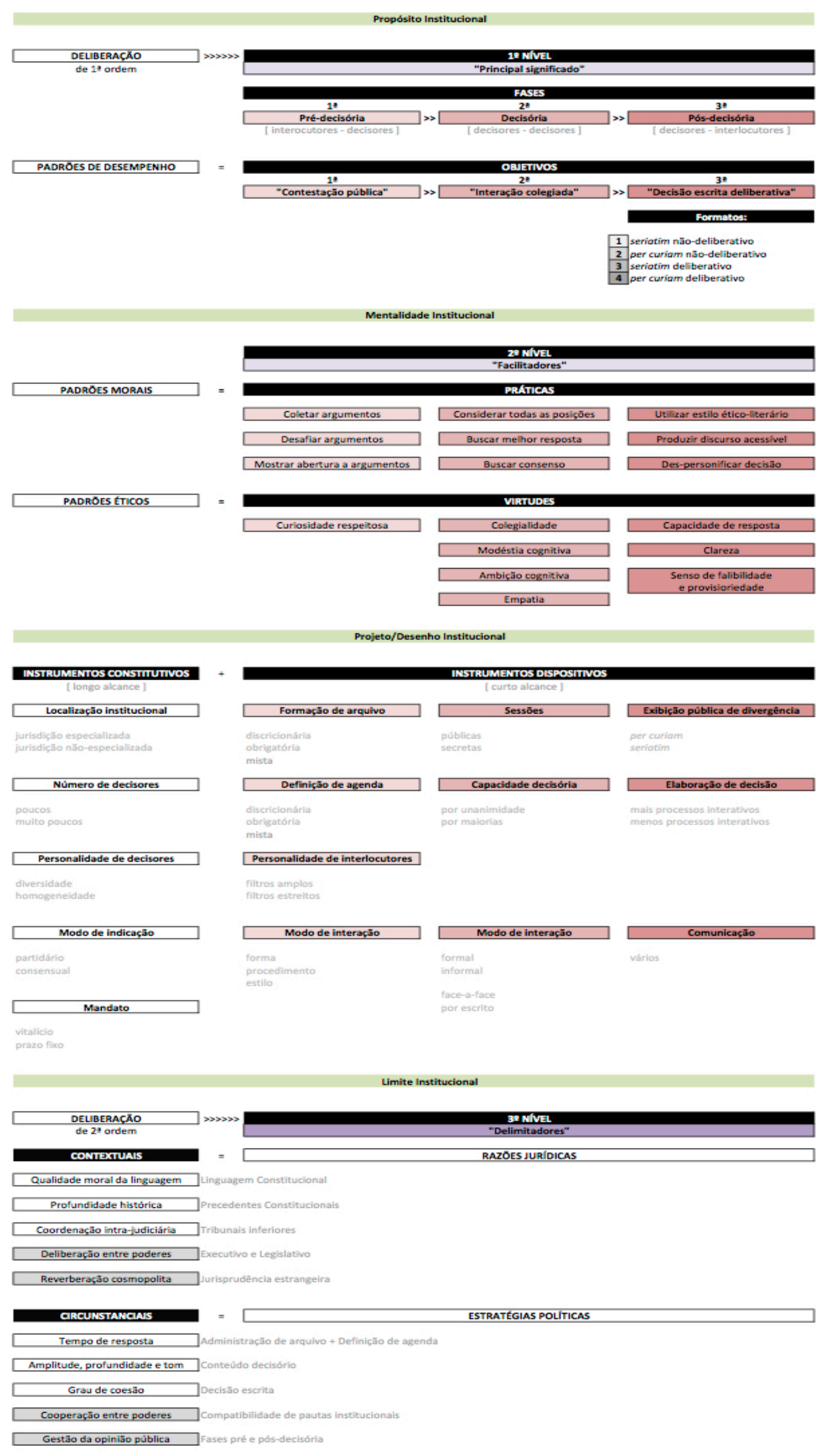




\section{Preenchendo o mapa deliberativo}

Ao concluirmos e observarmos tanto o atual contexto jurídico quanto as circunstâncias políticas ao redor do STF, esperamos que as páginas desta pesquisa favoreçam a elaboração de novas investigações lançando olhares mais detidos sobre seu funcionamento e as influências exercidas por esses componentes centrais em sua atuação. De toda forma, a tese construída por Mendes precisa passar por intensa crítica sobre seus diferentes postulados. Dito isto, o mapeamento deliberativo pode e deve ser criticado, mas sua estrutura oferece complementariedades e sinalizamos a esforços conjuntos diante da atual agenda de pesquisas sobre o STF. Vejamos exemplos.

Há poucos meses, Rogério Arantes e Diego Werneck Arguelhes, em Supremo: o estado da arte, forneceram um breve panorama dessa agenda. ${ }^{79}$ Do mesmo modo, Janelas de oportunidade, de Lívia Gil Guimarães, além de realizar uma espécie de balanço sobre a participação social no Supremo, também sugere o aprofundamento deste tipo de debate. ${ }^{80}$ Não obstante, ainda sobre as questões de mentalidade institucional e em termos de comportamento judicial, mencionamos novamente a pesquisa de Patrícia Perrone Campos de Mello, Nos bastidores do STF. Acreditamos que esta obra pode ser empregada para ajudar ao exame das práticas e virtudes dos ministros diante do processo decisório. Por este motivo, ao mesmo tempo, o trabalho de Mello poderia refinar o modelo avaliativo de Mendes.

\footnotetext{
${ }^{79} \mathrm{Cf}$. "Pesquisas mapeiam as forças e as fraquezas do STF, do individualismo dos ministros à busca por transparência". Artigo publicado na Revista Quatro Cinco Um, n. 10, ano II, abril de 2018, p. 14-15. Para uma reflexão sobre a participação social no âmbito do discurso jurídico, sugerimos MÜLLER, Friedrich. Quem é o povo? A questão fundamental da democracia. São Paulo: RT, 7ª ed., 2013. Também recomendamos o tema "constitucionalismo latino-americano".

${ }^{80}$ Cf. "Estudos sobre meios de participação da sociedade no Supremo apontam avanços democráticos, apesar de aspectos discutíveis", artigo publicado na mesma Revista Quatro Cinco $U m$, n. 10 , ano II, abril de 2018, p. 16. Este artigo pode ser analisado à luz da tarefa deliberativa de "promover a contestação pública", conexa aos institutos da audiência pública, amici curiae e também da própria sustentação oral realizada por advogados diante desta corte constitucional.
} 
Em outra linha, temos o trabalho de Felipe de Melo Fonte sobre o televisionamento nas cortes e, em especial, sobre o debate envolvendo as transmissões ao vivo das sessões de julgamento. Jurisdição constitucional e participação popular: o Supremo Tribunal Federal na era da TV Justiça, publicado em 2016, investiga o comportamento judicial e institucional do STF. ${ }^{81}$ Diante de nosso mapa deliberativo, esta pesquisa ajudaria a analisar a questão sobre a publicidade das sessões e a comunicação das decisões.

Enfim, há uma diversidade de trabalhos e projetos relevantes produzidos nos últimos tempos os quais podem contribuir à consolidação dos estudos sobre a corte brasileira a partir do modelo de Mendes. A produção científica sobre o STF pode dialogar com o modelo e, a partir da compartimentação feita neste trabalho, se conectar aos compartimentos cartografados no mapa. Como indicamos, o terreno para estudos da corte brasileira é amplo e seus esforços podem convergir em diferentes direções.

Em outra conta, o modelo seria aplicável à uma análise específica de casos constitucionais classificados entre fáceis e difíceis. Ou seja, propõe analisar a performance do STF em um determinado momento. À longo prazo, no entanto, o método de Mendes opera com materiais e informações suficientes para construir uma análise orientada por períodos históricos. Nesse sentido, a história desta instituição e a sua própria historiografia seriam componentes substanciais ao esforço de construir uma cronologia de transformações ou mesmo uma periodização institucional da corte. ${ }^{82}$

\footnotetext{
${ }^{81}$ Sobre as sessões, enquanto "premissas institucionais", John Ferejohn e Pasquale Pasquino defendem o segredo como opção ideal ao proporem uma teoria normativa positiva. Em sua fala no V CITI (ver nota 46), entretanto, Diego Werneck Arguelhes sustenta que "a ação está fora das lentes da TV Justiça". Assim, afirma a TV Justiça como um mecanismo de controle "verdadeiro" e, portanto, legitimado pelo público. Assim, “o que não é perceptível precisaria de publicidade”.

${ }^{82}$ Trata-se de reunir investigações em função da temporalidade do STF sob distintos recortes, possibilitando compreender suas transformações ao longo do tempo. A própria página eletrônica da corte brasileira fornece um "Histórico das Composições" a partir de seus diferentes MinistrosPresidentes: http://www.stf.jus.br/portal/composicaoPlenaria/composicaoPlenariaAnterior.asp.
} 


\section{Os novos desafios}

Como constatamos, existem inúmeras linhas de pesquisa a serem avançadas partindo deste modelo e pretendemos nos dedicar a elas. Com o esforço empreendido por este trabalho monográfico, podemos aplicar o modelo de Mendes ao processo decisório do Supremo Tribunal Federal para obtermos análises qualitativas de casos constitucionais. Esta iniciativa traria novas informações e possibilitaria reconhecermos êxitos e insuficiências do próprio modelo. Diante desta monografia esperamos não só caminhar neste sentido, mas também articular novos avanços investigativos sobre o campo jurídico no âmbito das Ciências Sociais. ${ }^{83}$

Como observamos, Mendes sugeriu duas propostas para influenciar o comportamento político de cortes: uma reforma institucional, tornando cortes menos partidárias mediante um novo modo de indicação e de mandato; e a comunidade jurídica exigir dos decisores o cumprimento de normas deliberativas voltadas a buscarem o consenso; exercerem uma ética de compromisso; além do autocontrole em relação à exibição pública de suas idiossincrasias pessoais. Mas como podemos abordar essas propostas?

Tornar o STF mais deliberativo, portanto, é a perspectiva em voga e ao fazermos uso desse novo método analítico, agora estruturado a partir deste trabalho, abrem-se possibilidades confirmando nossa hipótese: há um método e não só é aplicável ao STF como há material disponível para este tipo de análise. Logo, passaríamos à necessária apuração empírica desta corte não só para testar o modelo de Mendes, mas também semear as bases de uma análise institucional mais aprofundada mediante a reunião de outras pesquisas pré-existentes. Esta articulação implicará em novos desafios.

\footnotetext{
${ }^{83}$ Ver "A força do direito: elementos para uma sociologia do campo jurídico". In: BOURDIEU, Pierre. O poder simbólico. Rio de Janeiro: Bertrand, 1989. Ver FERREIRA, António Casimiro (coord.). Contextos e desafios de transformação das magistraturas: o contributo dos estudos sociojurídicos. Porto: Vida Económica, 2013. Sobre os estudos de Elites Jurídicas, convém mencionar os trabalhos de Yves Dezalay e Bryant Garth; e, no Brasil, os de Frederico de Almeida, Fabiano Engelmann, Fernando Fontainha, Renato Perissinotto, Adriano Codato e Luciano Da Ros.
} 


\section{REFERÊNCIAS BIBLIOGRÁFICAS}

ALARCON, Sylvio. Quem delibera? Representação, imparcialidade e legitimidade na democracia deliberativa. São Paulo: Revista Estudos Jurídicos (UNESP), n. 23, a. 16, 2012, p. 187-213.

ALMEIDA, Frederico de. A Nobreza Togada: as elites jurídica e a política da justiça no Brasil. Tese (Doutorado em Ciência Política) Universidade de São Paulo (FFLCH/USP). Orientado por Maria Tereza Aina Sadek, São Paulo, 2010.

ARGUELHES, Diego Werneck. A corte Aberta e seus inimigos: uma defesa contingente de publicidade em deliberações judiciais. In: Congresso Internacional de Teoria das Instituições, 5., Rio de Janeiro: Auditório Nelson Ribeiro Alves, Painel "STF em debate", 08 nov. 2018.

.; ARANTES, Rogério. Supremo: o estado da arte. São Paulo: Revista Quatro Cinco Um, a. 2, n. 10, abr. 2018, p. 14-15.

BARBOSA, Claudia M. O Processo de legitimação do Poder Judiciário Brasileiro. XIV Congresso do CONPEDI, Manaus, 2014. Disponível em: http://www.publicadireito.com.br/conpedi/manaus/arquivos/anais/XIVCong resso/080.pdf. Acesso em: 08 de Out. 2018.

BASTOS, Aurélio Wander (org.). Os cursos jurídicos no Brasil - 190 anos. Rio de Janeiro: IAB Nacional, 2017. 
BICALHO, Maria Fernanda; ASSIS, Virgínia Maria Almoêdo de; MELLO, Isabele de Matos Pereira de. Justiça no Brasil colonial - agentes e práticas. São Paulo: Alameda, 2016.

BONAVIDES, Paulo. Jurisdição constitucional e legitimidade (algumas observações sobre o Brasil). São Paulo: Revista Estudos Avançados (USP), v. 18, n. 55, 2004, p. 127-150.

BOURDIEU, Pierre. A força do direito: elementos para uma sociologia do campo jurídico. In: O poder simbólico. Rio de Janeiro: Bertrand, 1989. Cap. 7, p. 209-254.

BRANDÃO, Rodrigo (org.). Cortes Constitucionais e Supremas Cortes. Salvador: Juspodivm, 2017.

BRASIL. Supremo Tribunal Federal (STF). OAB pede instauração de comissão para avaliar dívida externa brasileira. Brasília: Notícias STF. 06 de dezembro de 2004. ADPF 59 (Daniel Sarmento). Disponível em: $<$ http://www.stf.jus.br/portal/cms/verNoticiaDetalhe.asp?idConteudo $=6392$ 4>. Acesso em: 18 nov. 2018.

- Regimento Interno: [atualizado até outubro de 2018] consolidado e atualizado até maio de 2002. Brasília, 2018. Disponível em: $<$ http://www.stf.jus.br/arquivo/cms/legislacaoRegimentoInterno/anexo/RIS TF_integral.pdf $>$. Acesso em: 18 nov. 2018. 
A Constituição e o Supremo [atualizada até outubro de 2018] - Secretaria de Documentação. Brasília: STF, 2018. Disponível em: $<$ http://www.stf.jus.br/portal/constituicao/>. Acesso em: 18 nov. 2018.

Histórico das Composições Plenárias. Brasília: STF, 2018.

Relação de ministros no período republicano. Disponível em: $<$ http://www.stf.jus.br/portal/composicaoPlenaria/composicaoPlenariaAnter ior.asp>. Acesso em: 18 nov. 2018.

CALAMANDREI, Piero. Eles, os juízes, vistos por um advogado. São Paulo: WMF Martins Fontes - 2a ed., 2015.

CARNEIRO, Igor de Lazari Barbosa. Decisões colegiadas e desenho institucional. Rio de Janeiro: LMJ Mundo Jurídico, 2018.

CARVALHO, Luiz Maklouf. Data venia, o Supremo - Como funciona e o que acontece no STF. Revista Piauí, seção Questões Jurídicas, n. 47, ago. 2010. Disponível em: <https://piaui.folha.uol.com.br/materia/datavenia-o-supremo/>. Acesso em: 19 set. 2018

O Supremo, quosque tandem? - A indiciação dos juízes, os pedidos de vistas, os conflitos de interesse, o ativismo e as disputas entre ministros - a agenda de dificuldades do STF. Revista Piauí, seção Questões Jurídicas, n. 48, set. 2010. Disponível em:< https://piaui.folha.uol.com.br/materia/o-supremo-quousque-tandem/>. Acesso em: 19 set. 2018. 
CLACSO. Coleción Estudios sobre las desigualdades. Buenos Aires: Consejo Latinoamericano de Ciencias Sociales, 2018. Disponível em: < https://www.clacso.org.ar/pobreza_y_desigualdades/publicaciones.php?s=6 \&idioma=>. Acesso em: 25 set. 2018.

COLON, Leandro. Exposição de ministros leva a questionamento. Folha de S. Paulo, seção Poder, Brasília, 30 jan. 2018. Disponível em: $<$ https://www1.folha.uol.com.br/poder/2018/01/1954358-exposicao-deministros-leva-a-questionamento-diz-carmen-sobre-critica-ao-stf.shtml>. Acesso em: 19 set. 2018.

CONTINENTINO, Marcelo Casseb. História do controle de constitucionalidade das leis no Brasil - Percursos do pensamento constitucional no século XIX (1824-1891). São Paulo: Almedina, 2015.

DINIZ, Antonio Carlos de Almeida. Teoria da legitimidade do Direito e do Estado: uma abordagem moderna e pós-moderna. São Paulo: Landy Editora, 2006.

ELSTER, Jon (ed.). Deliberative democracy. Cambridge: Cambridge University Press, 1998.

ESTLUND, David. Making truth safe for democracy. In: COPP, David; HAMPTON, Jean; ROEMER, John E. (eds.). The idea of democracy. Cambridge: Cambridge University Press, 1993, p. 71-100. 
FARIA, José Eduardo. A crise constitucional e a restauração da legitimidade. Rio de Janeiro: Revista de Ciência Política (FGV), v. 28, n. 2, mai./ago. 1985, p. 25-61.

FEREJOHN, John; PASQUINO, Pasquale. Rule of Democracy and Rule of Law. In: MARAVALL, José Maria; PRZEWORSKI, Adam. Democracy and the rule of law. Cambridge: Cambridge University Press, 2003, p. 242260.

FERREIRA, António Casimiro (coord.). Contextos e desafios de transformação das magistraturas: o contributo dos estudos sociojurídicos. Porto (Portugal): Vida Económica, 2013.

FICO, Carlos. Ditadura militar brasileira: aproximações teóricas e historiográficas. Florianópolis: Revista Tempo e Argumento (UDESC), v. 9, n. 20, jan./abr. 2017, p. 05-74.

FILHO, Newton Tavares. Democratização do processo de nomeação dos ministros do Supremo Tribunal Federal. Brasília: Biblioteca Digital da Câmara dos Deputados do Brasil, Estudo de Abril de 2006. Disponível em: http://bd.camara.gov.br/bd/handle/bdcamara/1596. Acesso em: 10 nov. 2018 .

FILHO, Hugo Cavalcanti Melo. Judiciário Oligárquico: déficit democrático e informalidade na administraçãoo dos tribunais e no governo da magistratura no Brasil. São Paulo: LTr, 2014. 
FURTADO, Celso. A pré-revolução brasileira. Rio de Janeiro: Fundo de Cultura, 1962.

FONTE, Felipe de Melo. Jurisdição constitucional e participação popular: o Supremo Tribunal Federal na era da TV Justiça. Rio de Janeiro: Lúmen Juris, 2016.

FORCE, Pierre. Self-interest before Adam Smith: a genealogy of economic science. Cambridge: Cambridge University Press, 2003.

FRIEDMAN, Barry. Taking Law Seriously. New York: Perspectives on Politics (NYU), vol. 4, n. 2, jun. 2006, p. 261-276.

GAMBETTA, Diego. Claro! An essay on discursive machismo. In: ELSTER, Jon (ed.). Deliberative Democracy. Cambridge: Cambridge University Press, 1998.

GUILHERME, Wanderley. Introdução ao estudo das contradições sociais no Brasil. Rio de Janeiro: ISEB, 1963.

GUIMARÃES, Lívia Gil. Janelas de oportunidade. São Paulo: Revista Quatro Cinco Um, a. 2, n. 10, abr. 2018, p. 16.

GOFFMAN, Erving. A situação negligenciada. In: RIBEIRO, Branca Telles; GARCEZ, Pedro M. Sociolinguística interacional: antropologia, linguística e sociologia em análise do discurso. Porto Alegre: Editora AGE, 1998, p. 13-20. 
HABERMAS, Jürgen. Between facts and norms: contributions to a discourse theory of law and democracy. Cambridge: MIT Press, 1996.

HAMILTON Alexander; JAY, John; MADISON, James. Federalist, n. 78, The Judiciary Departament, New York: McLean's Edition, 28 may. 1788.

HIRSCHMAN, Albert. Having opinions - One of the elements of wellbeing?. Nashville: The American Economic Review, n. 79, v. 2, 1989, p. $75-79$.

HUNDERT, E. J. The enlightenment's 'fable': Bernard Mandeville and the Discovery of society. Cambridge: Cambridge University Press, 2005. KELSEN, Hans. Wer soll der Hüter der Verfassung sein?. Wien: Die Justiz, n. 6, 1931, p. 576-628.

LABOV, William. Sociolinguística: uma entrevista com William Labov. Revista Virtual de Estudos da Linguagem - ReVEL, vol. 5, n. 9, ago. 2007. Tradução de Gabriel de Ávila Othero.

LATINOBARÓMETRO. Informe 2018/EI fin de la tercer ola de democracias. Santiago, Chile, 2018. Disponível em: <http://www.latinobarometro.org/lat.jsp>. Acesso em: 25 set. 2018.

LEITE, Carina Lellis Nicoll Simões. As audiências públicas no STF: mero instrumento de legitimação formal?. In: Daniel Sarmento (org.). Jurisdição Constitucional e Política. Rio de Janeiro: Forense, 2015. 
LEMOS, Renato. Contrarrevolução e ditadura no Brasil: elementos para uma periodização do processo político brasileiro pós-1964. Niterói: Revista Marx e o Marxismo (UFF), v. 2, n. 2, abr. 2014, p. 111-138.

MACIEL, Alice. Palestras e congressos aproximam empresas do Judiciário. In: A empresa de palestras de Rosângela Moro. São Paulo: Agência Pública de Jornalismo Investigativo, 25 jul. 2018. Disponível em: $<$ https://apublica.org/2018/07/a-empresa-de-palestras-de-rosangelamoro/?fbclid=IwAR3VGaJ3EMDvOD8c1sksW9r_L5Xg2Ikv4kfWquuh5k dQHijB1TycpIPiTa8>. Acesso em: 10 ago. 2018.

MARX, Karl. Das Kapital - Kritik der politischen Oekonomie [Buch I; Buch II; Buch III]. Hamburg: Verlag von Otto Meissner, 1867; 1885; 1894.

MARONA, Marjorie Corrêa; ROCHA Marta Mendes da. As audiências públicas do Supremo Tribunal Federal: ampliando sua legitimidade democrática?. Belo Horizonte: Revista Teoria e Sociedade (UFMG), n. 22, ano 1, jan./jun. 2014, p. 52-86.

MCCANN, Frank D. Resenha de HAINES, Gerald K. The americanization of Brazil: a study of U.S. Cold War diplomacy in the Third World, 1945-1954. Oakland: Pacific Historical Review (UC), n. 60, vol. 3, aug. 1991, p. 428-429.

MELLO, Patrícia Perrone Campos. A participação da subjetividade no comportamento judicial. In: - Nos bastidores do Supremo Tribunal Federal. Rio de Janeiro: Forense, 2015. Cap. 2, p. 57-145. 
MENDES, Conrado Hübner. O STF na democracia brasileira: vanguarda ilusionista. In: Congresso Internacional de Teoria das Instituições, 5., Rio de Janeiro: Auditório Nelson Ribeiro Alves, Painel "STF em debate", 08 nov. 2018.

. Magistrocracia, a "Gran Famiglia" judicial brasileira. Revista Época, nº 1.031, São Paulo, p. 82, 2 abr. 2018.

. O Supremo e seus personagens. São Paulo: Revista Quatro Cinco Um, a. 2, n. 10, abr. 2018, p. 13.

. Na prática, ministros do STF agridem a democracia.

Folha de S. Paulo, Ilustríssima, 28 de janeiro de 2018. Disponível em: $<$ https://www1.folha.uol.com.br/ilustrissima/2018/01/1953534-em-espiralde-autodegradacao-stf-virou-poder-tensionador-diz-professor.shtml $>$. Acesso em: 10 set. 2018.

. A Constituição na crise dos 30. Revista Época, nº 1.039, São Paulo, p. 122, 28 mai. 2018.

- Constitutional reasoning in the Brazilian 'Supremo Tribunal Federal' (STF). In: JAKAB, A.; DYERVE, A.; ITZCOVICH, G. (org.). Comparative Constitutional Reasoning. Cambridge: Cambridge University Press, 2016.

Constitutional courts and deliberative democracy. 1. ${ }^{a}$ ed.

Oxford: Oxford University Press, 2013. 
. O projeto de uma corte deliberativa. In: VOJVODIC, Adriana; PINTO, Henrique Motta; GORZONI, Paula; e SOUZA, Rodrigo Pagani de. (org.). Direito e Interpretação: racionalidades e instituições. $1^{\mathrm{a}}$ ed., São Paulo: Malheiros, 2012, p. 53-74.

- Desempenho deliberativo de cortes constitucionais e o STF. In: MACEDO JÚNIOR., Ronaldo Porto e BARBIERI, Catarina Helena Cortada (org.). Direito e Interpretação: racionalidades $e$ instituições. $1^{a}$ ed., São Paulo: Saraiva, 2011, p. 337-361.

Deliberative performance of constitutional courts. Tese (Doutorado em Filosofia do Direito) - Universidade de Edimburgo, Escócia. Orientado por Neil MacCormick e Neil Walker. Edimburgo, 2011.

Onze Ilhas. Folha de S. Paulo, seção Tendências/Debates, São Paulo, em 01 de fevereiro de 2010. Disponível em: $<$ https://www1.folha.uol.com.br/fsp/opiniao/fz0102201008.htm>. Acesso em: 17 set. 2018.

. Neither dialogue nor last word (Deliberative Separation of Powers III). Oxford: Legisprudence, v. 5, n. 1, 2011, p. 1-40.

. Not the last word, but dialogue (Deliberative Separation of Powers II). Oxford: Legisprudence, v. 3, n. 2, 2009, p. 191-246.

. Is it all about the last word? (Deliberative Separation of Powers I). Oxford: Legisprudence, v. 3, n. 1, 2009, p. 69-110. 
- Direitos fundamentais, separação de poderes e

deliberação. Tese (Doutorado em Ciência Política) - Universidade de São Paulo (USP). Orientado por Álvaro de Vita. São Paulo, 2008.

. Controle de constitucionalidade e democracia. Dissertação (Mestrado em Ciência Política) - Universidade de São Paulo (USP). Orientado por Álvaro de Vita. São Paulo, 2004.

MENDES, Gilmar Ferreira. Controle de constitucionalidade e processo de deliberaçãoo: legitimidade, transparência e segurança jurídica nas decisões das cortes supremas. Brasília: IDP, Observatório da Jurisdição Constitucional, Ano 4, 2010/2011. Palestra no evento "Diálogo Judicial Brasil-Estados Unidos - 2011”, 12 de maio de 2011. Disponível em: https://www.portaldeperiodicos.idp.edu.br/observatorio/article/view/551/0. Acesso em: 2 out. 2018.

MELLO, Fernando Collor de. Ruínas de um governo (11.05.2016) - A Sessão de Admissibilidade. In: . Réplica para a história: uma catarse. Brasília: Senado Federal, Gabinete do Senador Fernando Collor, 2016, p. 145-151.

MIGUEL, Luis Felipe. Consenso e conflito na democracia contemporânea. São Paulo: Editora Unesp, 2017.

Democracia e representaçãoo: terrirórios em disputa. São Paulo: Editora Unesp, 2014. 


\section{. Promessas e limites da democracia deliberativa. Resenha}

de John S. Dryzek, Deliberative democracy and beyond: liberals, critics, contestations. São Paulo: Revista Brasileira de Ciências Sociais (ANPOCS), vol. 16, n. 46, 2000, p. 175-177.

MÜllER, Friedrich. Quem é o povo? A questão fundamental da democracia. São Paulo: RT, $7^{\mathrm{a}}$ ed., 2013.

NALINI, José Renato. Como recrutar magistrados?. São Paulo: Revista USP, n. 101, p. 67-82, mar./abr./mai. 2014. Dossiê. Disponível em: $<$ http://www.revistas.usp.br/revusp/article/download/87815/90737/>.

Acesso em: 15 nov. 2018.

NINO, Carlos Santiago. The constitution of deliberative democracy. New Haven: Yale University Press, 1996.

NUNES, Rafael Bezerra. Como avaliar a performance das cortes constitucionais?. São Paulo, Portal JOTA, 13 abr. 2016. Disponível em: $<$ https://jota.info/artigos/como-avaliar-performance-das-cortesconstitucionais-13042016>. Acesso em: 15 out. 2018.

OLIVEIRA, Franklin de. Revolução e contrarrevolução no Brasil. Rio de Janeiro: Civilização Brasileira, 1962.

OLIVEIRA, Mariana. 50 anos do Golpe Militar. Brasília, Portal G1, 31 mar. 2014. Disponível em: <http:/g1.globo.com/politica/50-anos-do-golpemilitar/noticia/2014/03/golpe-de-1964-fez-do-supremo-um-enfeiteinstitucional-diz-pesquisador.html>. Acesso em: 15 abr. 2018. 
.; PASSARINHO, Nathalia. Luís Roberto Barroso toma

posse como ministro do Supremo. Brasília, Portal G1, 26 jun. 2013.

Disponível em: <http://g1.globo.com/politica/noticia/2013/06/luis-robertobarroso-toma-posse-como-ministro-do-supremo.html>. Acesso em: 12 out. 2018.

PASQUINO, Pasquale. Prolegômenos a uma Teoria do Poder Judiciário: o conceito de independência judicial na Teoria e na História. São Leopoldo: Revista de Estudos Constitucionais, Hermenêutica e Teoria do Direito, n. 2, v. 2, 2010.

PATEMAN, Carole. Participação e Teoria Democrática. Rio de Janeiro: Paz e Terra, 1992.

POST, Robert. Citizens divided - Campaign Finance Reform and the Constitution. Cambridge: Harvard University Press, 2014.

.; SIEGEL, Reva. Constitucionalismo democrático: por una reconciliación entre Constitución y Pueblo. Buenos Aires: SigloVeinteuno, 2013.

RANGEL, Henrique; BOLONHA, Carlos; e SEPULVEDA, Antonio. Cortes constitucionais e instrumentalização da legitimidade. Londrina: Revista do Direito Público (UEL), n. 1, v. 10, jan./abr. 2015, p. 171-187.

REZENDE, Maurício Corrêa de Moura. Democratização do Poder Judiciário no Brasil. São Paulo: Editora Contracorrente, 2018. 
RODRIGUEZ, José Rodrigo. Como decidem as cortes? Para uma crítica do direito (brasileiro). Rio de Janeiro: Editora FGV, 2013.

ROMANELLI, Sandro Luís Tomás Ballande. Suprema (in)dependência: mecanismos da relação entre governos e o Supremo Tribunal Federal. Tese (Doutorado em Direito). Curitiba: UFPR, 2016.

SABADELL, Ana Lucia. Manual de sociologia jurídica. São Paulo: Editora Revista dos Tribunais, $2017-7^{\mathrm{a}}$ ed.

SANTOMAURO, Fernando. A atuação política da Agência de Informação dos Estados Unidos no Brasil (1953-1964). São Paulo: Unesp, 2016.

SILVA, Claudia Maria Gil. Discursos de posse dos Presidentes do Supremo Tribunal Federal - Brasil, Capital Brasília: Uma das faces do ethos do Poder Judiciário. Rio de Janeiro: Lumen Juris, 2016.

SILVA, Virgílio Afonso da. Deciding without deliberating. Oxford: ICON, vol. 11, n. 3, 2013, p. 557-584.

- O STF e o controle de constitucionalidade: diálogo, deliberação e razão pública. Rio de Janeiro: Revista de Direito Administrativo (FGV), n. 250, 2009, p. 197-227. 
- Interpretação conforme a constituição: entre a trivialidade e a centralização judicial. Rio de Janeiro: Revista Direito GV (FGV), n. 1, v. 2, jan./jun. 2006, pp. 191-210.

Interpretação constitucional e sincretismo metodológico.

In: - Interpretação Constitucional, São Paulo: Editora

Malheiros, 2005, p. 115-146.

STONE-SWEET, Alec. Governing With Judges: constitutional politics in Europe. Oxford: Oxford University Press, 2000.

STRUCHINER, Noel e BRANDO, Marcelo. Como os juízes decidem os casos difíceis do direito? In: STRUCHINER, Noel e TAVARES, Rodrigo de Souza (orgs.). Novas fronteiras da teoria do direito: da filosofia moral à filosofia experimental. Rio de Janeiro: PoD: PUC-Rio, 2014, pp. 171- 219.

SCHWARTZ, Stuart. Burocracia e sociedade no Brasil colonial: o Tribunal Superior da Bahia e seus desembargadores (1609-1751). São Paulo: Companhia das Letras, 2011.

TEACHOUT, Zephyr. Corruption in America: from Benjamin Franklin's Snuff Box to Citizens United. Boston: Harvard University Press, 2014.

VALE, André Rufino do. A deliberação no STF: problemas atuais e propostas de aperfeiçoamento institucional. In: Congresso Internacional de Teoria das Instituições, 5., Rio de Janeiro: Auditório Nelson Ribeiro Alves, Painel "STF em debate", 08 nov. 2018. 
. La deliberación en los tribunales constitucionales. Madrid:

Marcial Pons, Coleción Estudios Constitucionales, 2017.

- Argumentação Constitucional: um estudo sobre a deliberação nos Tribunais Constitucionais. Tese (Doutorado em Direito) - Universidade de Brasília (UnB) e Universidad de Alicante (UA). Orientado por Claudia Rosane Roesler e Manuel Atienza. Brasília, 2015.

VERMEULE, Adrian. Mechanisms of Democracy: Institutional Design Writ Small. Cambridge: Oxford University Press, 2007.

VESTANA, Carolina. Participação ou formalismo? O impacto das audiências públicas no Supremo Tribunal Federal Brasileiro. Dissertação de Mestrado Profissional em Poder Judiciário. Rio de Janeiro: FGV, 2010.

Audiências públicas - Diagnóstico empírico sobre os limites da participação social. São Paulo: Revista Brasileira de Estudos Constitucionais (FGV), n. 24, ano 6, out./nov., 2012, pp. 973-1020.

VIANNA, Luiz Werneck; CARVALHO, Maria Alice Rezende de; MELO, Manuel Palacios Cunha; BURGOS, Marcelo Baumann. Corpo e alma da magistratura brasileira. Rio de Janeiro: Revan, 1997 - 3 a ed.

VOJVODIC, Adriana de Moraes et al. A construção das decisões na jurisdição constitucional: atores e deliberação no Supremo Tribunal Federal. In: Flávia Martins de Carvalho e José Ribas Vieira. Desafios da Constituição: Democracia e Estado no Século XXI. Rio de Janeiro: UFRJ, 2011, pp. 73-91. 
WALUCHOW, Wil. A common law theory of judicial review: the living tree. Cambridge: Cambridge University Press, 2007.

WEHLING, Arno; WEHLING, Maria José. Direito e justiça no Brasil colonial: o Tribunal da Relação do Rio de Janeiro (1751-1808). Rio de Janeiro: Renovar, 2004.

WERLE, Denilson Luís e MELO, Rurion Soares (org.). Democracia deliberativa. São Paulo: Singular, 2007.

WOLKMER, Antonio Carlos. Introdução ao pensamento jurídico crítico. São Paulo: Saraiva, $2012-8^{\mathrm{a}}$ ed.

. História do direito no Brasil. Rio de Janeiro: Forense, 2015 $-9^{\mathrm{a}}$ ed. 